\title{
Elenice Mantovani
}

\section{Identificação do agente etiológico da Doença de \\ Lyme-símile brasileira (Síndrome Baggio-Yoshinari)}

Tese apresentada à Faculdade de Medicina da Universidade de São Paulo para obtenção do título de Doutor em Ciências

Programa de Ciências Médicas

Área de concentração: Processos Imunes e Infecciosos

Orientador: Prof. Dr. Natalino Hajime Yoshinari

São Paulo

2010 
Dados Internacionais de Catalogação na Publicação (CIP)

Preparada pela Biblioteca da

Faculdade de Medicina da Universidade de São Paulo

Creprodução autorizada pelo autor

Mantovani, Elenice

Identificação do agente etiológico da Doença de Lyme-símile brasileira (Síndrome Baggio-Yoshinari) / Elenice Mantovani. -- São Paulo, 2010.

Tese(doutorado)--Faculdade de Medicina da Universidade de São Paulo.

Programa de Ciências Médicas. Área de concentração: Processos Imunes e Infecciosos.

Orientador: Natalino Hajime Yoshinari.

Descritores: 1.Doença de Lyme 2.Doença de Lyme-símile 3.Borrelia burgdorferi 4.Spirochaetales 5.Bactérias forma-L 6.Síndrome Baggio-Yoshinari 7.Brasil

USP/FM/DBD-308/10 
Dedico este trabalho ao meu pai, que apesar de não estar mais presente entre nós, será sempre o meu alicerce, meu motivo de orgulho e exemplo de vida a seguir. Tenho certeza de que de onde ele estiver, estará aplaudindo minha conquista, com o maior orgulho do mundo, como sempre fez.

À minha mãe e à minha avó por todo o amor, pela paciência e por estarem ao meu lado em todos os momentos da minha vida.

Ao meu grande amor, Glauber, pela dedicação, paciência e carinho prestados em período integral neste trabalho e principalmente na minha vida, acreditando e incentivando sempre cada passo dado. 


\section{Agradecimentos}

Ao meu orientador Prof. Dr. Natalino Hajime Yoshinari pela confiança, paciência e dedicação prestadas durante todos esses anos, sendo essencial para minha formação profissional e concretização deste trabalho.

À Profa. Dra. Eloísa Dutra de Oliveira Bonfá, Titular da Disciplina de Reumatologia da Faculdade de Medicina da Universidade de São Paulo por ter autorizado o meu ingresso na pós-graduação.

Ao Laboratório de Imunologia Celular, por ter cedido a cultura de células HUVEC, em especial à Solange Carrasco pelos ensinamentos e amizade.

À Prof. Dra. Elvira M $\mathrm{a}^{\mathrm{a}}$ Mendes do Nascimento (Setor de Riquétsias do Instituto Adolfo Lutz), por ter cedido a alíquota da cultura de Chlamydia pneumoniae, a qual foi usada como controle positivo nos ensaios.

Ao Prof. Dr. Jorge Timenetsky do ICB-USP, por ter cedido a cultura de Mycoplasma fermentans, a qual foi usada como controle positivo nos ensaios.

Ao Laboratório de Oncologia Experimental (LIM-24) pelo sistema de fotodocumentação utilizado durante este trabalho, e em especial às funcionárias Fátima Solange Pasini e Flavia Regina Rotea Mangone, por 
toda a paciência e ensinamentos que possibilitaram o aperfeiçoamento das técnicas de biologia molecular.

À Embrapa Gado de Corte (MS), em especial à Dra. Grácia Maria Soares Rosinha por ter proporcionado o estágio em biologia molecular, o qual foi de extrema importância no desenvolvimento desta tese, não esquecendo de agradecer a todos de sua equipe, principalmente à Dra. Renata Madureira pelos ensinamentos e companheirismo prestados.

Ao Prof. Dr. Marcelo Bahia Labruna do Departamento de Medicina Veterinária Preventiva e Saúde Animal (VPS) da Faculdade de Medicina Veterinária e Zootecnia da USP (FMVZ-USP) por ter cedido a alíquota da cultura de Borrelia anserina, a qual foi usada como controle positivo nos ensaios e também pela colaboração na interpretação dos sequenciamentos.

À todas da equipe do Laboratório de Síndrome Baggio-Yoshinari, Dra. Giancarla Gauditano pelo envio dos pacientes com suspeita de SBY para realização da pesquisa; à Virgínia Lucia N. Bonoldi pela paciência e por todos os ensinamentos prestados no laboratório durante todos esses anos; a Dra. Roberta Gonçalves Marangoni pela amizade e acima de tudo pela colaboração na fase final do projeto; à Marcela Helena Gambim pela amizade e pela ajuda nos momentos que precisei. 
À amiga Mariana Granziera Spolidorio pelos bons momentos de amizade compartilhados ao longo destes anos e pelo apoio no decorrer deste trabalho.

Aos amigos Mayra Fernanda Alves e Guilherme Anselmo, pela amizade e por toda a colaboração técnica durante o período em que estiveram presentes no laboratório.

À equipe do Laboratório de Matriz Extracelular, em especial a Dra. Walcy P. Rosolia Teodoro por ter me incentivado nos momentos mais difíceis, colaborando sempre que possível. A aprimoranda Natalia Cristina Borsonello pela amizade e, principalmente por toda a ajuda prestada no período em que esteve no laboratório.

$\grave{A}$ todas as pessoas que trabalham na Disciplina de Reumatologia da FMUSP e que de alguma forma colaboraram para a realização deste trabalho.

A todos os pacientes e controles que participaram deste protocolo, pois sem eles não seria possível a realização desta pesquisa.

À Fundação de Apoio à Pesquisa do Estado de São Paulo (FAPESP), pelo auxílio financeiro, concedendo-me a bolsa de doutorado direto. 


\section{Normatização adotada}

Esta tese está de acordo com as seguintes normas, em vigor no momento desta publicação:

Referências: adaptado de International Committee of Medical Journals Editors (Vancouver)

Universidade de São Paulo. Faculdade de Medicina. Serviço de Biblioteca e Documentação. Guia de apresentação de dissertações, teses e monografias. Elaborado por Anneliese Carneiro da Cunha, Maria Julia de A. L. Freddi, Maria F. Crestana, Marinalva de Souza Aragão, Suely Campos Cardoso, Valéria Vilhena. $2^{\mathrm{a}}$ ed. São Paulo: Serviço de Biblioteca e Documentação; 2005.

Abreviaturas dos títulos dos periódicos de acordo com List of Journals Indexed in Index Medicus. 


\section{Sumário}

Lista de Figuras

Lista de Tabelas

Lista de abreviaturas

Resumo

Summary

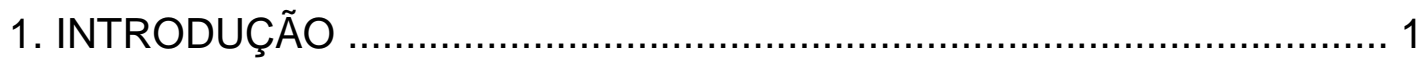

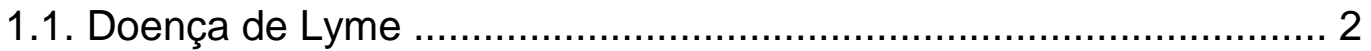

1.2. Histórico da pesquisa da DL no Brasil ........................................... 3

1.3. Síndrome Baggio-Yoshinari ................................................ 4

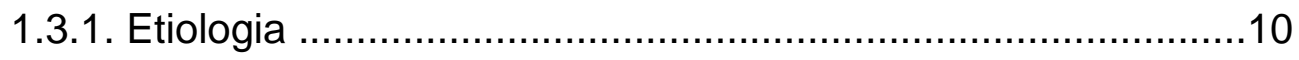

1.3.2. Vetores ….................................................................... 10

1.3.3. Reservatórios e hospedeiros .........................................12

1.3.4. Quadro clínico ...............................................................13

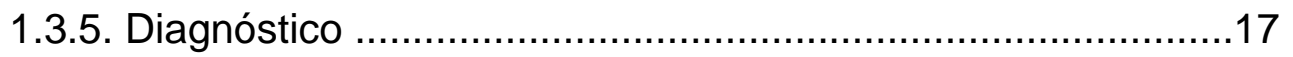

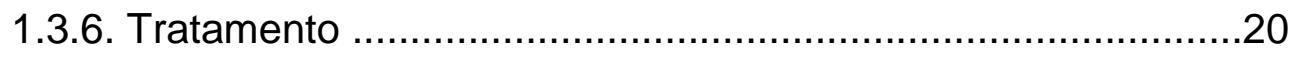

2. JUSTIFICATIVA DO ESTUDO .........................................................23

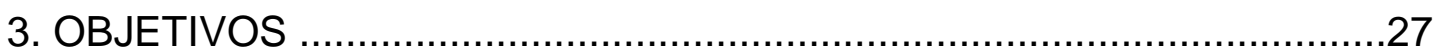

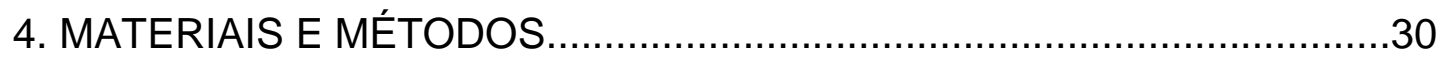


4.1. Casuística .31

4.2. Coleta e armazenamento dos materiais.............................40

4.3. Microscopia de campo escuro .....................................41

4.4. Meio de cultura SP-4 .....................................................41

4.5. Detecção de anticorpos anti Borrelia burgdorferi (WB)...........43

4.6. Detecção de anticorpos anti Borrelia burgdorferi (ELISA).......43

4.7. Detecção de anticorpos anti Mycoplasma pneumoniae pelo método de ELISA................................................................. 44

4.8. Detecção de anticorpos anti Chlamydia spp (IFI)..................45

4.9. Cultura de células endoteliais .........................................45

4.10. Coloração de Borrelia burgdorferi cultivadas em meios BSK e

SP-4 modificado.......................................................................

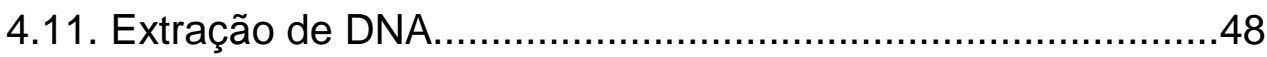

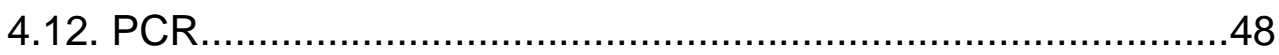

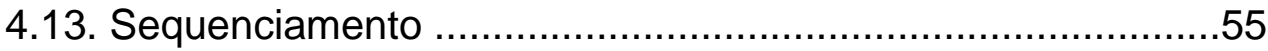

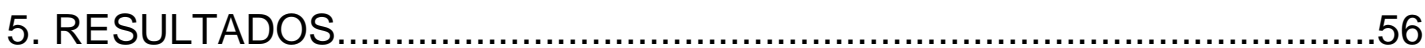

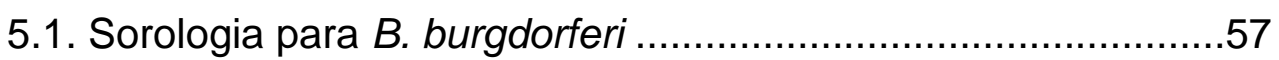

5.2. Sorologia para Mycoplasma pneumoniae.............................58

5.3. Imunofluorescência para Chlamydia spp..............................58

5.4. Microscopia de campo escuro .........................................59

5.5. Cultura de espiroquetídeos em meio SP-4............................60

5.6. Microscopia eletrônica ..................................................61

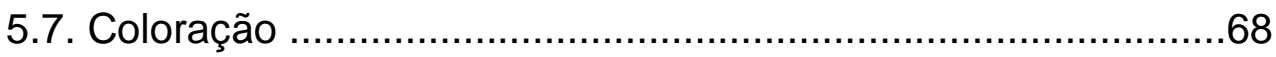




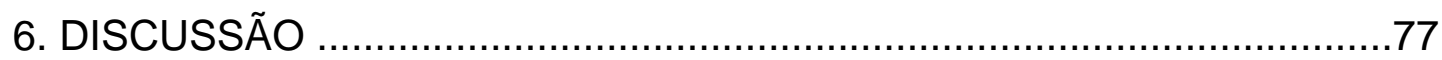

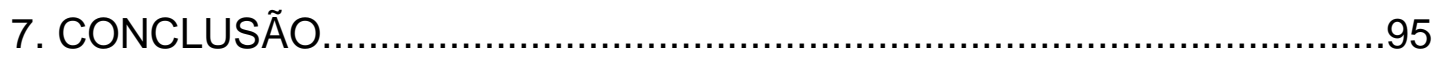

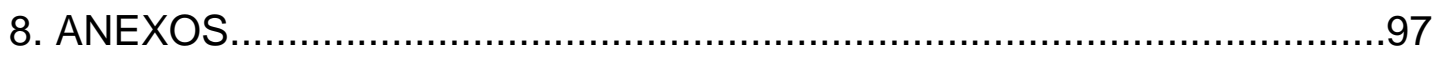

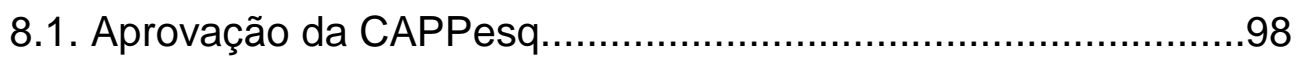

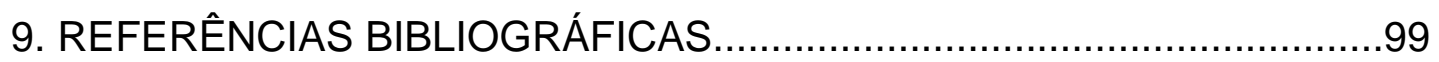

10. APÊNDICES

10.1. Comprovante de submissão do artigo para publicação

10.2. Artigo para publicação 


\section{Listas de figuras}

Figura 1 - Imunofluorescência Indireta para Chlamydia spp realizada com soro de paciente SBY.

Figura 2 - Cultura de sangue total de paciente com SBY inoculado em meio SP-4

Figura 3 - Amostra de sangue periférico de paciente com SBY, analisada à ME onde observa-se estruturas semelhantes a Chlamydia spp, espiroquetas, Mycoplasma spp e Archaebacteria spp.......

Figura 4 - Amostra de sangue periférico de paciente com SBY inoculado em meio SP-4, e analisado à ME onde observa-se estruturas semelhantes a espiroquetas e Mycoplasma spp ......

Figura 5 - $\quad$ Amostra de sangue periférico de paciente com SBY inoculado em meio SP-4, e analisado à ME onde observa-se estruturas semelhantes a espiroquetas.

Figura 6 - Amostra de sangue periférico de paciente com SBY inoculado em meio SP-4, e analisado à ME onde observa-se estruturas semelhantes a espiroqueta e Mycoplasma spp

Figura 7 - Amostra de sangue periférico de paciente com SBY inoculado em meio SP-4, e analisado à ME onde observa-se estrutura semelhante a espiroqueta.

Figura 8 - $\quad$ Amostra de sangue periférico de paciente com SBY inoculado em meio SP-4, e posteriormente em células endoteliais

Figura 9 - Cultura de Borrelia burgdorferi inoculada inicialmente em meio SP-4 por 3 dias e a seguir semeada em cultura de células endoteliais.

Figura 10 - Borrelia burgdorferi foi semeada em meio BSK e a seguir inoculada em cultura contendo células endoteliais.

Figura 11 - Borrelia burgdorferi mantida em cultivo no meio BSK, a seguir inoculada em cultura de células endoteliais mantidas em meio 199. 
Figura 12 - Cultura de B. burgdorferi em meio BSK, corada com Acridine orange e Azul de Evans........................................................ 68

Figura 13 - Cultura de B. burgdorferi em meio SP-4, corada pelo método de Acridine orange e Azul de Evans.

Figura 14 - Cultura de B. burgdorferi semeada em meio SP-4 e corada pelo Panótico.

Figura 15 - PCR realizada para identificar fragmento genético do plasmídeo cp32-4.

Figura 16 - PCR para o fragmento do gene flgE.

Figura 17 - PCR para o fragmento do gene flgE.

Figura 18 - Alinhamento das sequências das amostras positivas com o gene da Borrelia burgdorferi flagellar hook protein (flgE).

Figura 19 - Formação de estruturas císticas em cultura de B. burgdorferi após exposição aos antibióticos.

Figura 20 - Amostras de pacientes com SBY visualizadas à ME.

Figura 21 - Formação de "blebs" e grânulos em cultura de B. burgdorferi após 24 horas de incubação com ceftriaxona..

Figura 22 - Cultura de B. burgdorferi semeada em meio SP-4, corada pelo Panótico.

Figura 23 - Microscopia eletrônica mostrando Borrelia burgdorferi penetrando em células endoteliais.

Figura 24 - Cultura de Borrelia burgdorferi (cultivada em BSK) e inoculada posteriormente em células endoteliais.

Figura 25 - Microscopia Eletrônica de B. burgdorferi inoculada em tecido tonsilar. 


\section{Lista de tabelas}

Tabela 1 - Critério diagnóstico para SBY adotado pelo LIM-17 do HCFMUSP.

Tabela 2 - Frequência dos parâmetros maiores no grupo de 68 pacientes pertencentes ao grupo A com diagnóstico de SBY

Tabela 3 - Frequência dos parâmetros menores no grupo de 68 pacientes pertencentes ao grupo A com diagnóstico de SBY

Tabela 4 - Aspectos epidemiológicos, clínicos e sorologia para Borrelia burgdorferi G39/40 de origem americana nos 10 pacientes do grupo B com SBY

Tabela 5 - Tempo de evolução da doença desde o início da enfermidade, tratamento com antibióticos e sorologia para Borrelia burgdorferi nos 10 pacientes do grupo B com SBY na época da coleta do sangue. 


\section{Lista de abreviaturas}

ACA

$\mathrm{Bb}$

BSK

CAPPesq

CWDB

DL

DLSB

DMARDs

DMSO

DNA

EDTA

ELISA

EM

EUA

EV

FAN

FMUSP

HCFMUSP
Acrodermatite Crônica Atrófica

Borrelia burgdorferi

Barbour-Stoenner-Kelly

Comissão de Ética para Análise de Projetos de

Pesquisa

cell wall deficient bacteria

Doença de Lyme

Doença de Lyme-Símile Brasileira

Disease-modifying antirheumatic drugs

Dimetilsulfóxido

Deoxyribonucleic acid

Ethylenediamine tetraacetic acid

Enzyme Linked Immuno Sorbent Assay

Eritema migratório

Estados Unidos da América

Endovenosa

Fator antinuclear

Faculdade de Medicina da Universidade de São Paulo

Hospital das Clínicas da Faculdade de Medicina da Universidade de São Paulo 
IFI

Ig

LCR

LIM-17

ME

MMII

MO

Osps

PCR

SBY

SFC

SIRLS

SP-4

SSZ

STARI

TAPOS

TNF

UFRRJ

UNICAMP

vo

WB
Imunofluorescência indireta

Imunoglobulina

Líquido cefalorraquidiano

Laboratório de Investigação Médica em

Reumatologia

Microscopia eletrônica

Membros inferiores

Microscopia óptica

Outer surface proteins

Polymerase Chain Reaction

Síndrome Baggio-Yoshinari

Síndrome da Fadiga Crônica

Síndrome Infecto-Reacional Lyme-símile

Spiroplasma mirum base

sulfassalazina

Southern Tick Associated Rash Illness

Tick Associated Poly-Organic Syndrome

Tumor necrosis factor

Universidade Federal Rural do Rio de Janeiro

Universidade Estadual de Campinas

Via oral

Western Blotting 
Mantovani E. Identificação do agente etiológico da Doença de Lyme-símile brasileira (Síndrome Baggio-Yoshinari) [tese]. São Paulo: Faculdade de Medicina, Universidade de São Paulo; 2010. 117p.

A Doença de Lyme-símile brasileira ou Síndrome Baggio-Yoshinari (SBY) é uma zoonose emergente, transmitida por carrapatos e até o momento, de descrição restrita ao território brasileiro. O agente etiológico da SBY era desconhecido até o presente trabalho. O objetivo principal do estudo foi identificar a etiologia da SBY. Foi selecionado 2 grupos de pacientes: grupo $A(n=68)$ composto por pacientes com suspeita diagnóstica de SBY, a maioria na fase latente da doença; grupo $B(n=10)$, composto por pacientes com diagnóstico de SBY, que apresentaram obrigatoriamente eritema migratório e que encontravam-se sintomáticos no momento da coleta. Foi utilizado também um grupo controle composto por indivíduos saudáveis e com epidemiologia negativa $(n=50)$. Amostras de sangue foram coletadas para a realização de sorologias, culturas, análises microscópicas (óptica e eletrônica) e reação de cadeia da polimerase (PCR) para diferentes micro-organismos (Mycoplasma spp, Chlamydia spp e Borrelia spp). Além disso, foi realizado um estudo preliminar, através da PCR para Borrelia spp em 47 amostras de carrapatos oriundos de áreas de risco do Espírito Santo (sendo 17 Rhipicephalus microplus e 30 Rhipicephalus sanguineus), e amostras de sangue total de 27 bovinos e 26 equinos, animais estes oriundos da Universidade Federal Rural do Rio de Janeiro. Os resultados mostraram que a SBY não se trata de uma zoonose causada por um conjunto de micro-organismos como pensado inicialmente e sim pela Borrelia burgdorferi sensu lato. Descoberta essa que foi possível empregando-se novos primers amplificadores do principal gene envolvido na síntese do gancho flagelar da Borrelia, chamado flgE. A positividade para flgE foi confirmada em 6 pacientes do grupo B, 2 carrapatos, 1 bovino e 1 equino, os quais apresentaram homologia de $99 \%$ com o gene da proteína do gancho flagelar da Borrelia burgdorferi (flgE) depositado no GenBank (L43849). Esta importante descoberta, associada às pesquisas anteriores, permitiu definir a SBY como zoonose emergente e própria do país, causada pela bactéria $B$. burgdorferi na apresentação morfológica atípica, transmitida por carrapatos não pertencentes ao complexo Ixodes ricinus, responsável por manifestações clínicas semelhantes à Doença de Lyme, exceto pela grande frequência de sintomas recorrentes.

Descritores: Doença de Lyme, Doença de Lyme-símile, Borrelia burgdorferi, Spirochaetales, bactérias forma-L, Síndrome Baggio-Yoshinari, Brasil 
Mantovani E. Identification of the causative agent of Brazilian Lyme diseaselike illness (Baggio-Yoshinari Syndrome) [thesis]. São Paulo: "Faculdade de Medicina, Universidade de São Paulo"; 2010. 117p

Brazilian Lyme disease-like illness (BLDL) or Baggio-Yoshinari Syndrome (BYS) is an emerging zoonosis, transmitted by ticks and so far, restricted to the description of the Brazilian territory. The causative agent of BYS was unknown until now. The main objective of this study was to identify the etiology of BYS. We have selected two groups of patients: group $A(n=$ 68) consisting of patients suspected of BYS, mostly in the latent stage of disease; group B $(n=10)$, composed of patients diagnosed with BYS, who had compulsorily erythema migrans and that were symptomatic at the time of blood collection. We also used a control group composed of healthy individuals with negative epidemiology $(n=50)$. Blood samples were collected, in which we performed serology, cultures, microscopic analysis (optical and electron) and polymerase chain reaction (PCR) for different microorganisms (Mycoplasma spp, Chlamydia spp and Borrelia spp). In addition, a preliminary study was conducted by PCR for Borrelia spp in 47 samples of ticks from risk areas at Espirito Santo State (being 17 Rhipicephalus microplus and 30 Rhipicephalus sanguineus), 27 cattle and 26 horses, being these animals from the Universidade Federal Rural do Rio de Janeiro. The results showed that BYS is not a zoonosis caused by a set of microorganisms as initially thought, but by Borrelia burgdorferi sensu lato. These findings were possible after employing new primers that are able to amplify portions of the main genes involved in the synthesis of the Borrelia flagellar hook protein, called flgE. We confirmed positivity for the flgE in 6 patients from group B, 2 ticks, a cow, and a horse, which showed $99 \%$ homology with the gene of Borrelia burgdorferi flagellar hook protein (flgE) deposited in GenBank (L43849). This important discovery, coupled with previous research, helped to define BYS as an emerging zoonosis particular from Brazil, caused by B. burgdorferi of atypical morphologic presentation, transmitted by ticks outside the Ixodes ricinus complex, responsible for clinical signs similar to Lyme disease, except for the high frequency of relapsing symptoms.

Descriptors: Lyme disease, Lyme disease-like, Borrelia burgdorferi, Spirochaetales, L-form bacteria, Baggio-Yoshinari Syndrome, Brazil 
1. Introdução 


\subsection{DOENÇA DE LYME}

A Doença de Lyme (DL) foi descoberta em 1975 na comunidade de Old Lyme nos Estados Unidos da América (EUA), por Allen C. Steere, ao reportar casos sugestivos de artrite idiopática juvenil, antecedidos por picada de carrapatos e formação de lesão de pele denominada eritema migratório (EM) (Steere et al., 1977). O agente etiológico da DL foi identificado em 1982 por Willy Burgdorfer sendo denominado Borrelia burgdorferi (Burgdorfer et al.,1982). Contudo, convém lembrar que, pesquisadores europeus já conheciam diferentes aspectos da enfermidade desde o início do século XX, incluindo conhecimentos sobre o EM e a acrodermatite crônica atrófica (ACA), assim como queixas neurológicas como a Síndrome Bannwarth (meningopolirradiculite) (Lipschultz, 1913; Herxheimer, 1905; Lennoff, 1949).

Define-se a DL como zoonose encontrada nos EUA e Eurásia, transmitida por carrapatos do complexo lxodes ricinus, causada por espiroquetas do grupo Borrelia burgdorferi sensu lato, constituído pela $B$. burgdorferi sensu stricto encontrada nos EUA, Europa e Ásia, B. garinii e B. afzelii observadas na Europa, que causam inúmeras manifestações clínicas sistêmicas. Esta diversidade etiológica é responsável pelas diferenças clínicas e laboratoriais regionais. A B. burgdorferi sensu stricto causa em cerca de $80 \%$ dos casos nos EUA, EM e comprometimento articular (Steere, 2001). A B. garinii tem maior tendência de causar sintomas neurológicos e a B. afzelii é responsável pela lesão de pele conhecida como acrodermatite crônica atrófica (ACA). 
No sul dos EUA existe uma apresentação conhecida como doença de Masters ou STARI (Southern Tick Associated Rash IIIness) (Masters et al., 1998), caracterizada pelo desenvolvimento de "rash" semelhante ao EM, na ausência de sintomatologia sistêmica, sendo transmitida pelo Amblyomma americanum e causada pela $B$. Ionestari, a qual é incultivável em meio BSK e, recentemente tornou-se cultivável em células de carrapatos (Varela et al., 2004).

O carrapato transmissor da DL nos EUA e Eurásia pertence ao complexo Ixodes ricinus. Nos EUA encontra-se o l. scapularis e o l. pacificus; na Europa o I. ricinus e na Ásia o I. persulcatus. A DL é uma zoonose, onde os pequenos mamíferos como os roedores silvestres, assim como os grandes vertebrados como o veado nos EUA, participam do ciclo de transmissão da enfermidade. Larvas e ninfas de carrapatos infestam e contraem a infecção ao se alimentarem nos pequenos roedores, enquanto os artrópodes adultos transmitem para os mamíferos de grande porte. $\mathrm{O}$ homem contrai a zoonose adentrando no ecossistema propício, ao ser picado principalmente pelas ninfas dos carrapatos, que pelo seu tamanho diminuto, nem sempre são percebidos. Este aspecto é muito importante, pois a enfermidade só se desenvolve no homem, se o carrapato não for removido nas primeiras 24 horas. Nos vetores existe ainda a transmissão transovariana de espiroquetas (Spach et al., 1993; LoGiudice et al., 2003; Mladenović et al., 2010; Hamer et al., 2010).

A DL evolui por estágios. Na fase primária, em cerca de $80 \%$ dos casos norte-americanos, surge no local da picada, uma lesão de pele 
expansiva característica, conhecida como EM, geralmente de centro claro e borda avermelhada, que costuma durar dias a meses. A lesão pode assumir outros aspectos, como ser inteiramente eritematosa ou ser confluente a partir de minúsculas lesões menores. Quando a enfermidade é restrita à pele é chamada de localizada, e quando as borrélias disseminam no sangue, originam manifestações clínicas semelhantes a gripe, com presença de malestar, febre, cefaléia, artralgia, mialgia, calafrios e adenomegalia. Neste estágio podem surgir novas lesões de pele menos expansivas chamadas de anulares secundárias (Steere et al., 1980; Steere, 2001).

Nos pacientes não tratados na fase aguda, surge o estágio secundário da DL, semanas ou meses do contágio inicial, com envolvimento articular, neurológico ou cardíaco. Em relação ao aparelho locomotor, a artrite ocorre em cerca de $60 \%$ dos pacientes norte-americanos, geralmente de grandes articulações, em especial, com envolvimento do joelho. Os surtos de artrite podem ser recorrentes e durar semanas a meses. A biópsia da sinóvia e os achados do líquido sinovial são semelhantes aos observados na artrite reumatóide. Cerca de $10 \%$ dos pacientes com artrite de Lyme evoluem para artrite crônica com formação de cistos e erosões ósseas (Steere et al., 1988; Steere, 2001).

Sintomas neurológicos secundários da DL ocorrem em cerca de $15 \%$ dos casos nos EUA, e incluem sintomas da tríade: meningite, neurite craniana e radiculite periférica. A meningite é de padrão linfomonocitária com discreta proteinorraquia. Os sintomas são frustros e frequentemente diagnosticados apenas após punção e análise laboratorial do líquido 
cefalorraquidiano. Qualquer nervo craniano pode ser envolvido, mas o facial é o mais frequente, e quando de ocorrência bilateral é altamente sugestivo de DL. A neuropatia periférica pode ser sensitiva e/ou motora, e outras manifestações neurológicas podem ser reconhecidas na $\mathrm{DL}$ como a Síndrome de Guillain-Barré e encefalites (Oschmann et al., 1998; Steere, 2001).

Queixas cardíacas são raras, presentes em cerca de $8 \%$ dos pacientes com DL e manifestam-se na forma de arritmias ou miocardites. As arritmias, mesmo na forma de bloqueio átrio-ventricular completo não necessitam de marca-passo e regridem com tratamento clínico. A miocardite pode ser grave se houver invasão tecidual por espiroquetas (Steere, 1989; Steere, 2001).

A DL crônica decorre dos surtos recorrentes de artrite ou são complicações tardias da borreliose não tratada precocemente. Assim na neuroborreliose crônica descrevem-se as síndromes desmielinizantes, encefalopatias e ataxias. Na Europa existe a acrodermatite crônica atrófica (ACA), que é lesão de pele atrófica semelhante à esclerodermia e causada pela B. afzelii, e há exemplos de recuperação de borrélias a partir da pele em lesões com duração de muitos anos (Logigian et al., 1990; Strle et al., 1999; Steere, 2001).

A síndrome pós-DL ou TAPOS (Tick Associated Poly-Organic Syndrome) é uma entidade clínica observada nos EUA, bastante controversa e indefinida, que surge nos pacientes com DL tratados com antibióticos. Caracteriza-se pelo desenvolvimento de sintomas persistentes, com duração 
superior a 6 meses, como mialgia, artralgia, dor radicular, disestesias, sintomas neurocognitivos e intensa fadiga (Asch et al., 1994; Clarissou et al., 2009).

O diagnóstico da DL no Hemisfério Norte baseia-se na presença de sintomas clínicos, como o EM ou queixas sistêmicas articulares, neurológicas ou cardíacas, associado à sorologia positiva para $B$. burgdorferi. Nas áreas de risco, a simples constatação do EM é diagnóstico. O ensaio imunoenzimático (ELISA) é a prova laboratorial de triagem e na dúvida realiza-se o Western blotting (WB). O WB para ser considerado positivo para anticorpos das classes $\lg G$ ou $\lg M$, necessita mostrar determinado padrão de reatividade, tanto numérica como qualitativa, em relação às bandas protéicas das borrélias expressas no immunoblotting. A PCR é raramente utilizada na prática clínica, pois além de dispendioso, necessita que existam borrélias circulantes ou em tecidos (Grodzicki e Steere, 1988; Mandell et al., 1989; Dressler et al.,1993; Magnarelli, 1995).

O tratamento da DL baseia-se no emprego de antibióticos. Na fase aguda, as drogas indicadas são a doxiciclina na dose de $100 \mathrm{mg}$ duas vezes ao dia ou amoxicilina 500 mg 6/6 h ou azitromicina $500 \mathrm{mg} /$ dia pelo período de 3 semanas. Pacientes com envolvimento neurológico podem receber ceftriaxone $2 \mathrm{~g} / \mathrm{EV} /$ dia pelo período de 3 semanas.

No Hemisfério Norte não é aceito a persistência de espiroquetas no hospedeiro após uso adequado de antibióticos (Feder et al., 2007). Assim não se admite a hipótese de recorrência clínica e novo tratamento com antibióticos, com exceção de recidivas articulares que são interpretadas 
como manifestações de autoimunidade (Steere et al., 2001). Neste sentido, a denominação DL crônica é empregada para designar casos clínicos de diagnóstico tardio, que não foram tratados precocemente com antibióticos.

\subsection{HISTÓRICO DA PESQUISA DA DL NO BRASIL}

A pesquisa da DL no Brasil teve inicio em 1989 (Yoshinari et al., 1989) e após intensa divulgação do tema à classe médica brasileira, foram identificados os primeiros casos da enfermidade em 1992 na cidade de Itapevi, Estado de São Paulo (Yoshinari et al., 1992).

À medida que novos pacientes foram descobertos, verificaram-se grandes diferenças entre a DL descrita no Hemisfério Norte e no Brasil (Yoshinari et al., 1995; Yoshinari et al., 1997a; Yoshinari et al., 1999a; Costa et al., 2001; Yoshinari et al., 1999b). Do ponto de vista epidemiológico, não se identificavam carrapatos do complexo Ixodes ricinus hematófago para o homem nas áreas de risco, considerados vetores transmissores preferenciais da DL (Barros-Battesti et al., 2000). Clinicamente, apesar da ocorrência do clássico EM e das complicações sistêmicas habituais encontradas na $\mathrm{DL}$, a enfermidade brasileira cursava com recorrências, especialmente se 0 tratamento com antibióticos demorasse mais que três meses do início da infecção. Laboratorialmente, em nenhum momento foram isoladas bactérias do complexo $B$. burgdorferi sensu lato nos fluidos biológicos e em tecidos. A pesquisa de anticorpos contra $B$. burgdorferi de 
origem americana ou europeia (Pirana et al., 2000), embora relevante para o diagnóstico, revelava títulos baixos e oscilantes, desaparecendo rapidamente no sangue ou líquido cefalorraquidiano. Os doentes no Brasil, também exibiam alta frequência de autoanticorpos dirigidos contra diferentes constituintes celulares (Gauditano et al., 2000).

Assim, a enfermidade identificada no país, passou a receber inúmeras denominações como DL-símile, Síndrome Infecto-Reacional Lyme símile (SIRLS) (Mantovani et al., 2007a) ou Doença de Lyme símile Brasileira, com intuito de diferenciá-la da clássica DL.

O grande desafio na pesquisa da SIRLS era a identificação do agente etiológico. Ao contrário do observado nos EUA e Eurásia, a espiroqueta brasileira jamais fora cultivada em meio BSK, mesmo que após inúmeras modificações, a partir do sangue, líquido cefalorraquidiano ou amostras de pele (EM) (Costa et al., 2002; Mantovani et al., 2007a; Yoshinari et al., 2009) e nem tampouco a partir de carrapatos e do sangue de animais silvestres coletados em áreas de risco (Barros-Battesti et al., 2000; Abel et al., 2000).

Curiosamente, quando se analisava o sangue periférico de pacientes com SIRLS, assim como materiais biológicos provenientes de carrapatos e animais silvestres, identificavam-se estruturas pouco móveis com semelhanças às espiroquetas (espiroquetídeos), que não se desenvolviam em meio BSK, mas que cresciam temporariamente em meio chamado SP-4, ideal para o desenvolvimento de Spiroplasma spp, gênero de Mycoplasma que compõe o grupo dos Mollicutes, que são bactérias desprovidas de parede celular e tem membrana rica em colesterol. 
No intuito de pesquisar estes espiroquetídeos, realizou-se microscopia eletrônica (ME) em pequeno número de amostras de pacientes com SIRLS, que exibiam estes espiroquetídeos. De forma surpreendente, identificaram-se micro-organismos com estruturas morfológicas semelhantes à Mycoplasma spp, Chlamydia spp e espiroquetídeos sem flagelos (Mantovani et al., 2007a). Neste momento, aventou-se a hipótese da SIRLS ser causada por estes micro-organismos de comportamento latente, e a hipótese de tratar-se de borreliose ficou enfraquecida.

Aos poucos, nasceu a concepção da existência de uma nova zoonose brasileira, semelhante a DL, causada por agente etiológico ainda indefinido, que reproduzia a maioria das alterações clínicas encontradas na DL. Contudo, haviam inúmeras particularidades observadas na SIRLS, como a impossibilidade de cultivo do agente etiológico em meio BSK; ausência de isolamento de espiroquetas na morfologia espiralada helicoidal típica; a baixa resposta imunológica contra a $B$. burgdorferi e grande ocorrência de recorrências clínicas e de distúrbios imunoalérgicos.

O conjunto das informações altamente inusitadas e complexas de serem interpretadas, observadas apenas no território brasileiro e, portanto, difícil de serem transmitidas à classe médica do país, trouxe grande preocupação aos pesquisadores do LIM-17 do HCFMUSP. Decidiu-se que, seria necessário negar a existência da clássica DL no país, e propor a existência de uma zoonose inédita e emergente transmitida por carrapatos, chamada de Síndrome Baggio-Yoshinari (SBY). Este procedimento justificou-se pela existência de inúmeras diferenças nos aspectos 
epidemiológicos, etiológicos, clínicos, laboratoriais e terapêuticos, em relação à $\mathrm{DL}$ clássica.

\subsection{SÍNDROME BAGGIO-YOSHINARI}

\subsubsection{Etiologia}

A definição inicial da SBY (Gauditano et al. 2005) foi a de ser uma enfermidade de origem infecciosa, transmitida por carrapatos não pertencentes ao complexo l. ricinus, causada por micro-organismo(s) aparentemente de comportamento latente, ainda não identificado(s), possivelmente espiroquetas, que causava o EM e complicações clínicas sistêmicas semelhantes às observadas na $\mathrm{DL}$, exceto pela grande frequência de recorrências e de desordens imunológicas, ao longo da prolongada evolução clínica.

Contudo, para a completa caracterização da SBY, faltava identificar o agente etiológico. Não bastava dizer que havia um conjunto de microorganismos que simulavam Mycoplasma spp, Chlamydia spp e espiroquetídeos. Intrigava o fato dos pacientes com SBY, apesar das divergências citadas, reproduzirem a totalidade dos achados clínicos e laboratoriais da DL.

\subsubsection{Vetores}


Pesquisas de campo realizadas em localidades onde houve casos de SBY mostraram a ocorrência de carrapatos pertencentes às espécies Amblyomma cajennense e Ixodes loricatus (Barros-Battesti et al., 2000).

O gênero Amblyomma é o mais comum capaz de picar humanos no Brasil, mas outras espécies de carrapatos podem também desempenhar um papel relevante na ecologia e epidemiologia da SBY no Brasil. Acredita-se que o A. cajennense participe do ciclo epidemiológico da SBY, pois já houve relato de enfermidade que aconteceu após picada por esta espécie de carrapato (Yoshinari NH - comunicação pessoal).

Outros carrapatos podem ser vetores da SBY. Neste contexto, o carrapato mais comum no gado é o Rhipicephalus (Boophilus) microplus, um carrapato comum no Brasil que se alimenta predominantemente em hospedeiros não-humanos, podendo participar potencialmente do ciclo epidemiológico (bactérias / vetor / hospedeiro), mantendo os agentes infecciosos na natureza. Muitos agentes bacterianos foram detectados em $R$. microplus, incluindo Anaplasma marginale, Ehrlichia spp., Coxiella burnetti e B. theileri (agente etiológico da borreliose bovina) (Yparraguirre et al., 2007).

Além disso, os carrapatos da espécie $R$. microplus foram igualmente sugeridos como vetores da SBY, pois foi observada coexistência de anticorpos para B. burgdorferi e Babesia bovis em doentes com SBY, sendo este carrapato o agente responsável pela transmissão da babesiose em bovinos (Yoshinari et al., 2003).

Salienta-se que, no Brasil, nas áreas geográficas estudadas não se encontrou histórico de picadas em humanos por carrapatos do complexo $I$. 
ricinus, vetores essenciais na transmissão da DL clássica nos EUA e Eurásia (Guglielmone et al., 2006).

\subsubsection{Reservatórios e hospedeiros}

Pesquisas de campo em áreas de ocorrência da SBY mostraram a presença de roedores silvestres e marsupiais, considerados como potenciais animais reservatórios no Brasil, pois muitas vezes, visualizaram-se espiroquetídeos, que igualmente não se desenvolveram em meios de culturas BSK, e não foram identificados pela PCR, a exemplo do que ocorre em carrapatos e doentes com SBY (Costa et al., 2002; Abel et al., 2000).

Várias espécies de carrapatos podem coabitar no mesmo hospedeiro. Cães que entram na mata ou que compartilham seu ambiente com a fauna silvestre (Szabó et al., 2001), podem apresentar infestações mistas, por exemplo, A. cajennense, A. ovale e $R$. sanguineus. Da mesma forma, pequenos mamíferos silvestres que vivem próximos aos domicílios também podem apresentar dupla infestação. As capivaras e os gambás apresentam uma grande infestação por carrapatos do gênero Amblyomma (Perez et al., 2008).

Particularmente no Estado de Espírito Santo, existe uma importante associação entre a ocorrência de casos de SBY e a presença de capivaras, sugerindo que carrapatos que parasitam estes roedores, possam participar no ciclo epidemiológico da SBY. Igualmente importante é o surgimento de 
sintomas clínicos da SBY após contato com animais domésticos como cavalos, cachorros e bovinos (Spolidorio, 2009).

\subsubsection{Quadro clínico}

No Brasil, os pacientes são diagnosticados no seu estágio inicial ou latente (recorrência). Na fase aguda, definida arbitrariamente como enfermidade com menos de 3 meses de evolução após picada por carrapatos, nota-se que em cerca de $50 \%$ surge no local da picada, uma lesão macular ou papular, de crescimento centrífugo, de bordas eritematosas e centro mais claro, chamada de eritema migratório (Yoshinari et al., 1997a; Costa et al., 2001). Outras vezes, a lesão é homogeneamente avermelhada, e noutras situações, surge pelo coalescimento de múltiplas e minúsculas lesões puntiformes.

O período de incubação entre a picada e o desenvolvimento da lesão pode variar de 3 dias a semanas, sendo a média de 10 dias (Yoshinari et al., 1992; Yoshinari et al., 1997a; Costa et al., 2001). A lesão de pele costuma durar em média 30 dias, havendo casos em que o EM persiste por vários meses. Na fase de disseminação dos micro-organismos, ocorre surgimento de febre e outros sintomas gripais. Neste estágio, podem aparecer novas lesões de pele, múltiplas e menos expansivas que a inicial, chamadas de anulares secundárias. 
A fase de latência ou recorrência acontece quando não houve diagnóstico na fase aguda ou quando o tratamento convencional com antibióticos foi inadequado ou ineficiente, originando complicações secundárias cutâneas, neurológicas, articulares e cardíacas. O período entre a contaminação e o início das complicações sistêmicas é variável, oscilando de semanas a anos. No Brasil, as complicações articulares e neurológicas ocorrem em aproximadamente 35\% dos casos e as cardíacas em 5\% (Yoshinari et al., 1992; Yoshinari et al., 1997a; Yoshinari et al., 1999b). A artrite inicial é geralmente de padrão oligoarticular de grandes articulações, especialmente de joelhos. O surto inflamatório dura de semanas a meses, a biópsia da sinóvia revela inflamação inespecífica e o fluido sinovial exibe padrão inflamatório com elevado número de leucócitos (Yoshinari et al., 1995). Surtos iniciais de artrite tendem a regredir espontaneamente, mas nas fases de recidivas, existe a tendência ao desenvolvimento de poliartrite de caráter aditivo, com envolvimento de pequenas e grandes articulações, sem períodos de melhora, lembrando manifestações articulares da artrite reumatóide.

O quadro neurológico da SBY, a exemplo da DL, é caracterizado pela tríade: meningite linfomonocitária, neurite craniana e radiculopatia periférica, havendo descrição de casos de encefalite e/ou encefalomielite e distúrbios psiquiátricos (Shinjo et al., 2009).

A manifestação característica do envolvimento cardíaco é a arritmia, que pode durar meses, e costuma não necessitar de implantação de marca- 
passo (Yoshinari et al., 1997b; Yoshinari et al., 1999a; Yoshinari et al., 1999b).

Aspecto clínico distintivo da SBY é a alta frequência de recidivas, que ocorre em cerca de $75 \%$ dos casos, especialmente quando os doentes não são diagnosticados e tratados precocemente na fase aguda (Yoshinari et al., 1995; Shinjo et al., 2009). Importante salientar que, episódios de recorrências geralmente não são diagnosticados pelos médicos, pois os dados epidemiológicos ocorridos no passado, não são inquiridos ou associados com sintomas atuais. Ademais, manifestações cutâneas e sintomas gripais tendem a desaparecer ao longo da prolongada evolução clínica, dificultando ainda mais o diagnóstico dos casos de evolução prolongada (Shinjo et al., 2009). Apesar das dificuldades, o médico frente a um paciente suspeito de SBY em fase latente, deve estar atento e interrogar sobre acontecimentos ocorridos há anos ou décadas como: histórico prévio de picada por carrapatos, convivência anterior nas matas com animais silvestres e episódios pregressos de febre sem etiologia definida, lesões de pele (EM, lesão anular secundária), artrite, meningite, neuropatias cranianas ou periféricas, uveíte, distúrbios psiquiátricos etc.

Descreve-se a seguir, as principais manifestações clínicas observadas na SBY:

1- Cutâneas: eritema migratório, eritema anular secundário, linfocitoma benigno (Yoshinari et al., 2007), acrodermatite crônica atrófica (Mantovani et al., 2007a), paniculite (Mantovani et al., 2007a) e lesões 
de pele semelhantes à esclerodermia no local inicial da picada (Fonseca et al., 2005).

2- Ósteo-musculares: artrite, artralgia, miosite, Síndrome da Fadiga Crônica (SFC). Esta Síndrome é definida como cansaço físico ou mental com duração superior a 6 meses que não melhora com repouso, e é exacerbado por atividades físicas. Define-se SFC na presença de 4 dos seguintes sintomas: fadiga prolongada, cefaléia, mialgia, diminuição de memória ou concentração, artralgia, dor de garganta, adenomegalia cervical e distúrbio do sono.

3- Neurológicas: meningite linfomonocitária; neurite de nervos cranianos (paralisia facial, diplopia, surdez, disfagia, dislalia, nevralgia do trigêmeo); radiculopatias periféricas sensitivo-motoras; síndrome de Guillain-Barré; mononeurite multiplex, convulsões, encefalomielite, encefalopatia, disfunção esfincteriana (Shinjo et al., 2009).

4- Distúrbios cardíacos como arritmias e insuficiência cardíaca por cardiomegalia (Yoshinari et al., 1997b; Yoshinari et al., 1999a; Yoshinari et al., 1999b).

5- Distúrbios psiquiátricos como depressão grave, tentativas de suicídio, síndrome do pânico, transtorno bipolar, esquizofrenia (Shinjo et al., 2009).

6- Distúrbios de adequação social como fuga de escolas, busca de isolamento, abandono de empregos (Shinjo et al., 2009).

7- Distúrbios oculares intrínsecos como uveíte, corioretinite e arterite retiniana (Sato et al., 2003). 
8- Distúrbios do cognitivo que incluem diminuição de memória, dificuldade de expressão, distúrbios do sono, dificuldades de concentração, memorização ou raciocínio (Shinjo et al., 2009).

9- Disfunções imunoalérgicas como maior sensibilidade a drogas e alimentos, urticárias e sintomas graves como edema angioneurótico adquirido (Yoshinari et al., 1995).

\subsubsection{Diagnóstico}

O diagnóstico da SBY é difícil de ser realizado, especialmente na fase latente e o LIM-17 do HCFMUSP preconiza um guia diagnóstico baseado na presença de parâmetros maiores e menores (Tabela 1) (Mantovani et al., 2007a).

Tabela 1 - Critério diagnóstico para SBY adotado pelo LIM-17 do HCFMUSP

\section{PARÂMETROS MAIORES}

PARÂMETROS MENORES

- Epidemiologia compatível quando do início da infecção: picada, · Episódios de recorrência visita às áreas de risco, visualização de carrapatos no ambiente ou animais, animais doentes no local.

- Sorologia positiva para Borrelia burgdorferi (ELISA ou WB) nos Visualização de "espiroquetídeos" padrões adotados no LIM-17 do HCFMUSP à $\mathrm{MO}$

- Clínica pertinente: EM ou complicação sistêmica (articular, - Síndrome da Fadiga crônica neurológica, cardíaca ou ocular)

FONTE: Mantovani et al., 2007a

NOTA: Considera-se caso positivo na presença de três critérios maiores ou dois maiores e dois menores simultaneamente. 
Os dados laboratoriais devem ser interpretados com cuidado. Exames que indicam atividade inflamatória aguda como a velocidade de hemossedimentação, proteína C reativa e mucoproteínas podem estar negativos, mesmo na vigência de processos inflamatórios como artrite, meningite ou neurite (Yoshinari et al., 1995). Esta dissociação clínicolaboratorial é um aspecto importante da SBY, e mostra indiretamente, o quanto os micro-organismos estão adaptados ao hospedeiro. Enfermos com anemia, leucopenia, elevação de transaminases ou bilirrubinas podem ter coinfecções com outras zoonoses transmitidas por carrapatos como a babesiose e a ehrlichiose. Doentes que desenvolvem torpor, confusão mental ou coma, na vigência de exantema cutâneo, devem ser pesquisados para rickettsioses, como a febre maculosa brasileira ou novas rickettsioses ditas brandas, causadas por Rickettsia parkeri, R. amblyommii, $R$. felis, $R$. bellii, $R$. rhipicephali.

O procedimento sorológico para demonstrar anticorpos anti $B$. burgdorferi foi modificado no LIM-17 do HCFMUSP (Costa, 1998; Barros, 2000), e o médico deve estar atento ao fato de que os títulos dos ensaios no país são baixos e flutuantes, com riscos de se encontrar casos falsos positivos e negativos. Na falta do isolamento do agente brasileiro, empregase a $B$. burgdorferi cepa G39/40 de origem americana nos ensaios sorológicos (ELISA e WB). Dentre as enfermidades que cursam com sorologia falso-positiva temos a sífilis; leishmaniose visceral; doenças autoimunes como lúpus eritematoso sistêmico, esclerodermia, artrite reumatóide; infecções virais; rickettsioses agudas; neuropatias crônicas (Yoshinari et al., 
1999b; Yoshinari et al., 1997b). Doentes com SBY desenvolvem sorologia positiva (ELISA ou WB) para B. burgdorferi em aproximadamente $65 \%$ dos casos, enquanto nos indivíduos normais, a frequência de positividade é de aproximadamente 16\% (Mantovani et al., 2007b). Na fase aguda da zoonose ocorre predomínio de anticorpos da classe IgM e na convalescência de lgG, mas esta distinção tende a desaparecer nos surtos de recorrências (Yoshinari et al., 1995). As pequenas oscilações de títulos ou de resultados não indicam que houve modificações na evolução clínica. Vale ressaltar que a interpretação dos resultados de sorologias realizadas com metodologias adaptadas ao nosso meio é diferente das realizadas nos EUA e Eurásia.

O ELISA é realizado com antígeno sonicado total de $B$. burgdorferi cepa G39/40 de origem americana e segue metodologia adotada nos EUA. Em contrapartida, a interpretação do WB no Brasil é diferente da preconizada no Hemisfério Norte, pois valoriza-se a quantidade de bandas presentes e não a ocorrência de bandas específicas, como é preconizada nos outros continentes. A pesquisa de anticorpos anti B. burgdorferi (ELISA) no líquido cefalorraquidiano (LCR) pode ser útil quando houver suspeita de acometimento neurológico na SBY, mas tem as mesmas restrições do estudo sorológico. Em geral, indivíduos normais não apresentam anticorpos anti Borrelia no LCR, mas o teste ELISA pode ser positivo em inúmeras enfermidades infecciosas ou autoimunes (Yoshinari et al., 1995).

Pesquisas recentes realizadas no LIM-17 do HCFMUSP indicam que pacientes com SBY desenvolvem autoanticorpos ao longo da prolongada evolução clínica (Yoshinari et al., 1995; Gauditano et al., 2000). Outros 
dados ainda não publicados indicam que cerca de $50 \%$ dos pacientes com SBY apresentam autoanticorpos contra extrato de membrana de neurônios humanos, confirmando estudos anteriores, que já haviam revelado existência de anticorpos contra proteína de núcleo caudado de coelhos em doentes com SBY (Gauditano et al., 2000). Outras desordens imunológicas também foram descritas no Brasil, como surgimento dos anticorpos contra fator antinuclear (FAN) e anticardiolipina, hipergamaglobulinemia e elevação de $\lg E$ (Yoshinari et al., 1995).

\subsubsection{Tratamento}

O tratamento depende do estágio da SBY, aspecto nem sempre fácil de ser definido, exceto quando defrontamos com paciente com histórico agudo, que desenvolveu EM após picada por carrapato e que frequentou área de risco recentemente. Em geral, os doentes procuram o médico na vigência de complicações tardias, e nestas condições, como foi salientado anteriormente, o diagnóstico e tratamento são extremamente complexos.

A infecção primária da SBY é tratada com doxiciclina 100 mg duas vezes ao dia pelo prazo mínimo de 30 dias. Crianças podem receber amoxilina ou azitromicina pelo mesmo período. Surtos recorrentes iniciais podem ser medicados com os mesmos antibióticos pelo período prolongado de três meses, mas os resultados da terapêutica são inconstantes (Mantovani et al., 2007). 
$\mathrm{Na}$ presença de complicações neurológicas como meningite, encefalite, neurite, ou na vigência de artrite recorrente, pode-se empregar ceftriaxona 2g/EV/dia por 30 dias, seguido de dois meses adicionais de doxiciclina $100 \mathrm{mg}$ duas vezes ao dia. Nesta fase costuma-se associar hidroxicloroquina na dose de $400 \mathrm{mg} /$ dia por tempo prolongado, embora não esteja totalmente demonstrado, se esta opção terapêutica seria mais eficiente, que o uso isolado da doxiciclina pelo período de três meses. Sintomas como fadiga crônica e distúrbios de cognição respondem pouco ao uso de antibióticos e costumam merecer outras formas de abordagem terapêutica (Mantovani et al., 2007; Shinjo et al., 2009).

Não existe um consenso sobre o tratamento da SBY de evolução clínica prolongada com episódios de recidivas. Há casos de boa resposta aos antibióticos, assim como os não responsivos. No Serviço de Reumatologia do HCFMUSP, os doentes com envolvimento articular prolongado, no estágio poliarticular e recorrente, recebem o mesmo tratamento preconizado aos pacientes com artrite reumatóide, ou seja, são tratados com anti-inflamatórios e drogas modificadoras da evolução da artrite reumatóide (DMARDs). Recomenda-se prudência no emprego de terapia biológica com anti TNF, pois houve caso de agravamento da SBY quando se empregou esta modalidade de tratamento em paciente com artrite recorrente sem resposta ao uso de outros DMARDS (Yoshinari NH - comunicação pessoal).

Novas pesquisas estão em desenvolvimento no LIM-17 do HCFMUSP como a de entender o papel dos autoanticorpos na patogênese da SBY. 
Existe a busca de novos marcadores sorológicos que permitam distinguir neuropatia ou artrite crônica da SBY das demais afecções consideradas específicas como a esclerose múltipla, artrite reumatóide ou espondiloartrites. Com frequência, o médico frente ao paciente com SBY recorrente, fica indeciso em saber o momento exato de parar de insistir com antibióticos e buscar novas alternativas terapêuticas.

Em resumo, com exceção das apresentações iniciais da SBY, que costumam responder bem aos antibióticos, não há um consenso sobre o tratamento das formas latentes e recorrentes da SBY. Convém salientar que, mesmo no Hemisfério Norte não há unanimidade de opinião sobre diferentes aspectos da DL, incluindo o modo de tratamento dos pacientes com TAPOS (Tick Associated Poly-Organic Syndrome) e DL crônica (Clarissou et al., 2009). 
2. Justificativa do estudo 
O maior desafio no conhecimento da SBY refere-se à identificação do agente etiológico, o qual tem sido incultivável em meios de culturas habituais para borrelias no Brasil. Mantovani et al. (2007) haviam descrito a presença de micro-organismos latentes com morfologia semelhante a Mycoplasma spp, Chlamydia spp e espiroquetas sem flagelos observados na microscopia eletrônica em pequena amostra de pacientes. Na época desta descoberta, acreditava-se que estes micro-organismos de comportamento latente fossem os agentes etiológicos da SBY.

Contudo, a existência de semelhanças entre a DL e a SBY continuava a intrigar pesquisadores do LIM-17 do HCFMUSP, pois a hipótese desta nova zoonose ainda ser uma borreliose, não estava totalmente afastada. A equipe estava convencida que novas pesquisas deveriam enveredar para 0 caminho da biologia molecular, pois o agente etiológico era incultivável no país. Assim, pensou-se no estudo de novos genes bacterianos, potencialmente preservados e essenciais às funções de infectividade e sobrevivência deste(s) micro-organismo(s) em hospedeiros vertebrados e invertebrados.

O genoma da $B$. burgdorferi é composto por um cromossomo linear e mais de 20 plasmídeos entre lineares e circulares. (Wang et al., 1999). Ainda é desconhecido o porquê desta segmentação genômica, mas os plasmídeos são essenciais na produção de diferentes proteínas da Borrelia, como as enzimas que Ihes permitem sobreviver às diferentes condições adversas "in vivo" (Stewart et al., 2005), desempenhando funções na resistência a antibióticos, infectividade etc. 
Purser e Norris (2000) tentaram identificar plasmídeos associados à infectividade em $B$. burgdorferi cepa B31 usando painel de 19 isolados clonais. O plasmídeo Ip25 exibiu uma correlação direta com a virulência e estava presente em todos os clones com níveis altos e intermediários de infectividade e ausente nos clones de baixa infectividade. Verificaram que o Ip 28-1 também estava relacionado com virulência.

Os genes do complexo cp32 estão preservados na maioria das cepas de $B$. burgdorferi e caracterizam-se também por estarem presentes na febre recorrente causada pela espiroqueta $B$. hermsii, sugerindo que podem ser essenciais para a sobrevivência das borrelias (Stewart et al., 2005). Além disso, plasmídeos não são facilmente perdidos, durante o deslocamento bacteriano do seu ambiente natural (reservatório ou carrapato) para os seres humanos (lyer et al., 2003).

Ao longo das pesquisas, outro fato chamou a nossa atenção. Foi a presença da banda de $41 \mathrm{Kda}$ no WB de pacientes com SBY, indicativo de presença de anticorpos contra aparelho flagelar bacteriano, a despeito de pesquisas prévias sugerirem inexistência de espiroquetas flageladas no país.

Contudo, publicações demonstraram que a estrutura do flagelo periplasmático é composta de um corpo basal, um gancho e um filamento contendo uma proteína flagelar (flagelina) maior (FlaB) e uma menor (FlaA) (Barbour e Hayes, 1986; Ge et al., 1998). A síntese do flagelo é regulada por uma cascata de eventos, envolvendo a expressão de vários genes (Aldridge e Hughes, 2002; Sal et al.,2008). 
Assim, na tentativa de elucidar as diferentes dúvidas surgidas, propomos a realização da pesquisa com os seguintes objetivos: 
3. Objetivos 
1- Identificar o agente etiológico da SBY, com emprego de novos primers, provenientes de genes potencialmente preservados entre as diferentes cepas de borrelias.

2- Realizar PCR em amostras de carrapatos e sangue de animais domésticos, oriundos de áreas de risco, com primers efetivos no reconhecimento do agente etiológico da SBY.

3- Pesquisar se ocorre infecção por Mycoplasma spp, Chlamydia spp e Borrelia spp em grupo de pacientes com SBY, através de procedimentos sorológicos e moleculares (PCR).

4- Analisar amostras de sangue periférico de pacientes com SBY à microscopia eletrônica, no intuito de confirmar a presença de microorganismos de morfologia latente.

5- Estudar aspectos do comportamento microbiológico dos agentes etiológicos da DL e SBY, como capacidade de crescimento dos microorganismos em diferentes meios de cultivos, analisando-se modificações morfológicas e suas características tintoriais. Bactérias 
visualizadas em pacientes com SBY serão também inoculadas em culturas de células endoteliais, para testar o potencial infectante destas estruturas. 
4. Materiais e Métodos 


\subsection{Casuística}

\subsubsection{Grupo A}

Foram selecionados 68 pacientes com SBY (sendo 19 agudos e 49 latentes), que preencheram o critério diagnóstico adotado no LIM-17 do HCFMUSP (Tabelas 2 e 3), entre os pacientes externos ao complexo Hospital das Clínicas, encaminhados no período compreendido entre maio de 2005 a janeiro de 2007, para a realização de sorologias para B.burgdorferi. Nesta casuística, 23 pacientes eram do sexo masculino $(33,8 \%)$ e 45 do sexo feminino $(66,2 \%)$, com idades que variaram de 08 a 71 anos, sendo que a média de idade foi de 44 anos e o desvio padrão de 15,1 anos. Convém lembrar que, apesar de 35,3\% terem referido EM, este achado geralmente esteve ausente no dia da coleta do sangue, sendo portanto, dado de história pregressa.

Cinquenta indivíduos normais também foram selecionados como grupo controle, sendo 15 do sexo masculino (30\%) e 35 do sexo feminino (70\%), com idades que variaram de 18 a 54 anos, sendo que a média de idade foi de 31,8 anos e o desvio padrão de 10,5 anos. Todos relataram não terem sido picados por carrapatos e nem frequentar áreas de risco. 
Tabela 2 - Frequência dos parâmetros maiores no grupo de 68 pacientes pertencentes ao grupo A com diagnóstico de SBY

\begin{tabular}{lcc}
\hline \multicolumn{1}{c}{ Parâmetros maiores } & Pacientes & Frequência \\
& (N=68) & (\%) \\
\hline História prévia de picada por carrapato & 43 & 63,2 \\
Contato com animais e/ou visita às áreas de risco & 65 & 95,6 \\
Eritema migratório & 24 & 35,3 \\
Artrite & 5 & 7,3 \\
Cardiopatia & 8 & 11,7 \\
Neuropatia & 20 & 29,4 \\
Sorologia positiva para Bb (ELISA ou WB) & 44 & 64,7 \\
\hline
\end{tabular}

Tabela 3 - Frequência dos parâmetros menores no grupo de 68 pacientes pertencentes ao grupo A com diagnóstico de SBY

\begin{tabular}{lcc}
\hline \multicolumn{1}{c}{ Parâmetros menores } & $\begin{array}{c}\text { Pacientes } \\
(\mathbf{N}=68)\end{array}$ & Frequência \\
& $4 \%)$ \\
\hline Episódios recorrentes & 49 & 72 \\
Fadiga & 40 & 58,8 \\
Mialgia & 28 & 41,2 \\
Artralgia & 46 & 67,6 \\
Desordens do cognitivo & 11 & 16,2 \\
Parestesia de extremidades & 1 & 1,5 \\
Visualização de espiroquetídeos a MO (n=52) & 49 & 94,2 \\
\hline
\end{tabular}




\subsubsection{Grupo B}

No período compreendido entre novembro/2008 a outubro/2009, foram selecionados 10 pacientes com diagnóstico de SBY, que apresentaram obrigatoriamente eritema migratório (EM) e que estavam sintomáticos, sendo 6 do sexo feminino e 4 do sexo masculino. As idades variaram de 10 a 68 anos, sendo a média de 39,6 anos e o desvio padrão de 22,9 anos.

Neste grupo, todos relataram visita prévia às áreas de risco para a zoonose e $50 \%$ haviam sido picados por carrapato. Nove doentes desenvolveram sintomas gripais na fase aguda, como febre, cefaléia, mialgia, calafrios e fadiga. Queixas ósteoarticulares foram reportadas em 8 casos e em 4 foi observada artrite durante o seguimento clínico evolutivo. A sorologia para B.burgdorferi mostrou positividade em $40 \%$ dos casos, considerando-se o ensaio de ELISA e Western blotting na época da coleta do sangue (Tabela 4). 
Tabela 4 - Aspectos epidemiológicos, clínicos e sorologia para Borrelia burgdorferi G39/40 de origem americana nos 10 pacientes do grupo B com SBY

\begin{tabular}{lcc}
\hline \multicolumn{1}{c}{ Dados } & No de casos & Freqüência (\%) \\
\hline Visita às áreas de risco & 10 & $\mathbf{1 0 0}$ \\
Picada por carrapato & 5 & 50 \\
Sintomas gripais & 9 & 90 \\
Eritema & 10 & $\mathbf{1 0 0}$ \\
Artrite & 4 & $\mathbf{4 0}$ \\
Artralgia & 8 & $\mathbf{8 0}$ \\
Sorologia positiva para Borrelia burgdorferi & 4 & $\mathbf{4 0}$ \\
\hline
\end{tabular}

Cinco pacientes apresentavam história aguda, com tempo de evolução da enfermidade de até 90 dias do início do contágio, enquanto outros 5 estavam na fase latente (de 105 dias a 1440 dias), mas com queixas de pele ou artrite. Quatro pacientes estavam em tratamento com antibióticos no momento da coleta de sangue (Tabela 5). 


\begin{tabular}{|c|c|c|c|c|}
\hline CASO & IDADE & $\begin{array}{c}\text { TEMPO DE EVOLUÇÃO } \\
\text { (dias) }\end{array}$ & $\begin{array}{c}\text { TRATAMENTO } \\
\text { (na coleta de sangue) }\end{array}$ & $\begin{array}{c}\text { Sorologia } \\
\text { para } B b\end{array}$ \\
\hline 1 & 68 & 9 & cefalexina por 4 dias & negativa \\
\hline 2 & 51 & 30 & não & negativa \\
\hline 3 & 31 & 60 & cefalexina por 3 dias & positiva \\
\hline 4 & 67 & 11 & não & positiva \\
\hline 5 & 30 & 105 & não & negativa \\
\hline 6 & 60 & 270 & não & positiva \\
\hline 7 & 11 & 270 & penicilina benzatina há 10 dias & negativa \\
\hline 8 & 15 & 30 & tetraciclina por 7 dias & negativa \\
\hline 9 & 10 & 360 & não & negativa \\
\hline 10 & 53 & 1440 & não & positiva \\
\hline
\end{tabular}

\subsubsection{Descrição detalhada dos pacientes do grupo B com SBY}

1: feminino, 68 anos. Foi picada por carrapato em uma pousada em São Roque, onde havia um bambuzal. Apresentou EM, artralgia, sintomas gripais. Estava tomando cefalexina há 4 dias. Compareceu ao laboratório após 9 dias após o início dos sintomas para coleta de sangue. Sorologia negativa para Borrelia burgdorferi.

2: feminino, 51 anos. Picada por carrapato em Ubatuba no tornozelo. $\mathrm{Na}$ região, havia muitos animais circulando entre as pessoas (ex: cães com carrapatos). Desenvolveu EM, artralgia (joelho e mãos), calafrios, cefaléia, nucalgia, gânglios na região inguinal (causando dores na coxa). Compareceu ao laboratório após 30 dias do início dos sintomas para coleta de sangue. Sorologia negativa para Borrelia burgdorferi. 
3: feminino, 31 anos. Viajou para Juquitiba para participar de um evento. Durante sua estadia, não viu carrapatos e nem teve picadas. Após 14 dias da viagem, começou a apresentar: febre diária de $37,5^{\circ} \mathrm{C}$, poliartralgia (migratória em membros superiores) e múltiplas manchas. Após 23 dias, artrite em joelhos, pés e mãos, muita fadiga, artralgia, febre e manchas recorrentes (poucas). Tomou 3 dias de cefalexina. Compareceu ao laboratório após 60 dias do início dos sintomas para coleta de sangue. Sorologia positiva para Borrelia burgdorferi (WB: 1 banda para $\operatorname{lgG} / 3$ bandas para $\lg \mathrm{M})$.

4: masculino, 67 anos. Foi picado por carrapato 11 dias antes da coleta de exame, na região de Vinhedo (SP) com desenvolvimento de EM. Sorologia positiva para Borrelia burgdorferi (WB: 2 bandas para $\operatorname{lgM}$ ).

5: feminino, 30 anos. Fez visita à Ilha Grande. Sintomas apareceram após 15 dias, incluindo sintomas gripais, sensação de febre (calafrios), fadiga, artrite importante nos dedos das mãos, mialgia e nucalgia. Apresentou ainda artrite em joelhos e cotovelos. Vem desenvolvendo lesões de pele, as quais são recorrentes, nas pernas, pés, braços e abdômen. As lesões eritematosas tem caráter expansivo e escurecem. Sorologia negativa para Borrelia burgdorferi.

6: masculino, 60 anos. Contraiu a infecção quando trabalhava na Floresta Amazônica, desenvolvendo na época, EM na perna D e sintomas gripais. 
Procurou infectologista na cidade de Manaus, que fez o diagnóstico de DL e prescreveu doxiciclina $100 \mathrm{mg}$ de 12/12h por 15 dias. Após aproximadamente 8 meses, desenvolveu artrite, quando a sorologia para Borrelia burgdorferi realizada no LIM-17 do HCFMUSP foi positiva (WB: 4 bandas para $\lg G)$.

7: masculino, 11 anos. Adquiriu a enfermidade na cidade litorânea de Ubatuba, SP, após adentrar na Mata Atlântica e sofrer picadas de insetos, que não soube precisar. Desenvolveu EM na hemiface $E$ acompanhado de febre baixa, cefaléia e poliartralgia. Após cinco meses, apresentou artrite em joelhos, febre e dificuldade de movimento em braços e dedos das mãos. Devido à persistência dos sintomas foi medicado com penicilina benzatina 1.200.000 U. Sorologia negativa para Borrelia burgdorferi.

8: feminino, 15 anos. Viajou para Bonito (MS), onde foi picada por carrapatos (região da Serra da Bodoquena), e após 3 dias iniciou quadro de febre até $38,9^{\circ} \mathrm{C}, \mathrm{EM}$ em braço esquerdo, acompanhado de fraqueza, enjoo, dores nas pernas e braços, cefaléia e dor de estômago. Ao retornar à SP, procurou serviço médico e foi medicada com tetraciclina por 7 dias. Compareceu ao LIM-17 do HCFMUSP após 30 dias do início do quadro para realizar exames, e devido a persistência de sintomas como distúrbios do cognitivo (raciocínio, sonolência), cefaléia, mialgia e fraqueza, foi orientada a tomar doxiciclina $100 \mathrm{mg} / 2 \mathrm{x}$ ao dia por no mínimo mais 2 meses. Sorologia negativa para $B$. burgdorferi. 
9: masculino, 10 anos. Frequentou sítio na região de Itatiba (SP), onde teve contato com animais infestados por carrapatos. Após 10 dias do retorno da viagem, iniciou quadro de prurido generalizado intermitente, persistente e diário, com lesões eritematosas expansivas em tronco e MMII, acompanhado por febre, artralgias generalizadas, cefaléia e mialgia. Iniciou tratamento com corticóides (administrado devido a edema angioneurótico), antialérgicos (sem remissão das lesões) e anti-inflamatórios, referindo melhora das dores com o uso regular das drogas. Após 6 meses, sem melhora das lesões, iniciou quadro de poliartrite acompanhada por febre baixa. Iniciou tratamento com anti-inflamatório não hormonal e antitérmico, com melhora do quadro na vigência da medicação. Compareceu ao LIM-17 do HCFMUSP para coleta de exames, cerca de 360 dias após o início dos sintomas, sem uso de antibióticos e apresentava-se sintomático com lesões de pele e artrite. Sorologia negativa para B. burgdorferi.

10: feminino, 53 anos. Refere que há cerca de 4 anos, após entrar em mata (Caconde-MG) para colocar apiários, notou carrapato fixado na região abdominal E, com surgimento de eritema e prurido local. Retirou o parasito com álcool, tendo notado que a lesão eritematosa não melhorava. Após cerca de um mês, a lesão aumentou ao redor da origem da picada, mantendo-se eritematosa, não pruriginosa. Na mesma época iniciou cefaléia holocraniana, de duração contínua, de 2 a 3 dias, de difícil controle, tendo usado analgésicos. Nega febre. Refere desde então artralgias em joelhos D e E, quadril D, com uso regular de anti-inflamatório não hormonal, com 
melhora das dores. Após seis meses, sem melhora da lesão, procurou dermatologista, tendo aplicado pomada local com pouca melhora da vermelhidão cutânea. Refere que a lesão aumentou centrifugamente tendo permanecido estável em tamanho com cerca de $10 \mathrm{~cm}$ de diâmetro por 5 de largura, mudando de cor e ficando mais endurecida. Após três anos sem melhora procurou o ambulatório de Reumatologia por artralgias tendo sido solicitada avaliação do serviço de dermatologia, e feito biópsia no local da lesão. $\mathrm{Na}$ avaliação ambulatorial a paciente apresentava lesão eritematosa localizada em flanco E de cerca de $10 \times 5 \mathrm{~cm}$ de circunferência, espessada, com bordas bem regulares e acentuadas pelo eritema. Apresentava dores em joelhos com discreta sinovite. Foram realizados exames gerais e específicos para afastar outras infecções e doenças autoimunes, todos negativos. Foi encaminhada para o Serviço de Reumatologia, quando a minuciosa revisão da história clínica, dados epidemiológicos, sintomas compatíveis e sorologia positiva para B. burgdorferi, permitiram concluir tratar-se de SBY. Foi medicada com ceftriaxona, $2 \mathrm{~g} \mathrm{EV}$, seguida do uso de doxaciclina, havendo melhora do tamanho da lesão e do eritema, do espessamento de pele, da cefaléia e das artralgias. Foi solicitada avaliação da dermatologia, que realizou biópsia de pele que mostrou dermatite perivascular edematosa com raros eosinófilos e aumento de colágeno sugestivo de esclerodermia. Após seis meses do início de tratamento e dois meses, em uso de difosfato de cloroquina evoluiu com dor aguda em quadril D, com dificuldade para deambular, com febre baixa não medida. Feito novamente sorologia para B. burgdorferi que mostrou-se positiva, sendo 
medicada com nova série de ceftriaxona $2 \mathrm{~g} / \mathrm{EV} /$ dia por 30 dias, com remissão da dor, porém com dificuldade de deambulação. Feito nova série de doxiciclina, com orientação de não entrar em mata, e mudança de medicação de manutenção, de cloroquina para sulfassalazina (SSZ). Paciente permanece em acompanhamento há dois anos mantém-se medicada com SSZ $2 \mathrm{~g} \mathrm{VO/dia} \mathrm{com} \mathrm{melhora} \mathrm{importante} \mathrm{dos} \mathrm{sintomas}$ articulares, porém com persistência das lesões de pele, no mesmo local do original e aumento das lesões cutâneas em tronco. Quando a paciente ficou assintomática, sem quadro articular ou cefaléia, mantendo apenas a lesão de pele, foi suspensa medicação e solicitada nova sorologia para $B$. burgdorferi que resultou positiva (WB: 2 bandas para $\lg M)$. Neste estágio realizou nova biópsia de pele com extração de DNA para PCR.

\subsection{Coleta e armazenamento dos materiais}

Os pacientes suspeitos dos grupos A e B foram encaminhados ao LIM-17 do HCFMUSP, pelos médicos de outras Instituições como o Instituto de Infectologia Emílio Ribas ou outras Universidades Públicas (UNICAMP, Ribeirão Preto), para a coleta de sangue para pesquisa de anticorpos anti $B$. burgdorferi. No dia da coleta foi preenchido um breve questionário contendo dados clínicos e epidemiológicos, que junto com os dados sorológicos permitiram ou não a inclusão do enfermo no grupo da SBY. 
O trabalho foi aprovado pela Comissão de Ética (CAPPesq - no 0895/05) (Anexo 8.1.) e os pacientes e controles assinaram o termo de consentimento informado.

Amostras de sangue foram coletadas em tubos seco e com EDTA. O tubo seco foi centrifugado para a obtenção do soro, já o tubo com EDTA foi utilizado para a realização de PCR para pesquisa de Mycoplasma spp e Chlamydia spp (somente para o grupo A) e Borrelia spp (para os grupos A e B). Outros procedimentos incluíram preparo de lâminas para microscopia de campo escuro e em alguns casos a semeadura do sangue em meio de cultura SP-4, além de envio de amostras para a microscopia eletrônica (somente para o grupo A).

\subsection{Microscopia de campo escuro}

Colocou-se numa lâmina 1 a 2 gotas de soro, homogeneizado com uma pequena quantidade de hemácias, apoiando uma lamínula sobre a lâmina. Procedeu-se a leitura em microscópio de campo escuro.

\subsection{Meio de cultura Spiroplasma mirum base SP-4 (Fritz et al., 1991) (modificado)}

Seguiu-se o seguinte protocolo para o preparo do meio de cultura SP-4: 
- PPLO broth base: $13 g$

- Bacto-tryptone (Difco): 10g

- Bacto-peptone (Difco): $5 g$

- Phenol red: $20 \mathrm{~g}$

- Água deionizada: 615mL

Autoclavou-se os reagentes acima a $121^{\circ} \mathrm{C}$ por $15-20$ minutos.

Após esterilização, filtrou-se e adicionou-se os seguintes reagentes:

- CMRL 1066 (10x), 4,9g:50mL

- Yeastolate solution (2\%), 2g: $100 \mathrm{~mL}$

- Soro fetal bovino: $170 \mathrm{~mL}$

Foram feitas alíquotas do meio de aproximadamente $6 \mathrm{~mL}$ em tubo de vidro para cultura com tampa de rosca. Armazenou-se a $-20^{\circ} \mathrm{C}$.

Para o cultivo, descongelou-se a alíquota em banho-maria, deixandoa atingir a temperatura de $36^{\circ} \mathrm{C}$.

O tubo contendo o meio foi aberto próximo ao bico de Bunsen, passando a extremidade do tubo sobre o mesmo.

Adicionou-se ao meio aproximadamente $1 \mathrm{~mL}$ de sangue total. $\mathrm{O}$ tubo foi fechado e levado à estufa $\left(36^{\circ} \mathrm{C}\right)$.

A análise foi realizada após 72 horas. No caso de um bom crescimento de estruturas, uma alíquota foi enviada para Microscopia Eletrônica e/ou adicionada a uma cultura de células endoteliais. 


\subsection{Detecção de anticorpos anti Borrelia burgdorferi pelo Western}

blotting (Dressler et al., 1993; Costa, 1998; Barros, 2000).

Para realização do WB procedeu-se a eletroforese vertical do extrato total de $B$. burgdorferi cepa G39/40 (obtido através do sonicado total da $B$. burgdorferi cepa G39/40, de origem americana, inicialmente isolada de carrapatos Ixodes scapularis, conservado congelado em nitrogênio líquido), reduzido com dithiothreitol (Bio Rad) em gel de poliacrilamida a 10\%.

As proteínas do gel foram transferidas para o papel de nitrocelulose com porosidade de 0,2 $\mu \mathrm{m}$. Após transferência do antígeno, o papel de nitrocelulose foi corado com Ponceau (por 10 minutos) e lavado com água destilada para retirar o excesso do corante e cortado em tiras, as quais foram bloqueadas (tampão Tris (TBS) - Tween 0,1\% - leite desnatado $5 \%$ pH 7,4), lavadas, incubadas com as amostras (diluição 1:100), lavadas, incubadas com conjugado (anti-IgM ou anti-IgG humano conjugado à enzima fosfatase alcalina), lavadas e reveladas.

\subsection{Detecção de anticorpos anti Borrelia burgdorferi pelo método} imunoenzimático (ELISA) (Grodzicki e Steere, 1988; Mandell et al., 1989; Costa, 1998; Barros, 2000)

As placas, Immulon 1B (Thermo Electron Corporation, USA), foram sensibilizadas, com $100 \mu \mathrm{l}$ de sonicado total de Borrelia burgdorferi cepa G 
39/40 na concentração de $15 \mu \mathrm{g} / \mathrm{ml}$ diluído em tampão carbonato pH 9,6 e mantidas a $4^{\circ} \mathrm{C}$ em câmara úmida durante a noite. Lavou-se as placas 3 vezes com tampão fosfato (PBS) com $0,05 \%$ de Tween 20 , $\mathrm{pH} 7,4$.

Após sensibilização, os sítios inespecíficos das placas foram bloqueados com $100 \mu \mathrm{l}$ por poço de solução protéica feita com leite desnatado à 5\%, diluído em tampão fosfato com $0,5 \%$ de Tween 20, $\mathrm{pH} 7,4$. Incubou-se as placas por 1 hora, à temperatura ambiente. Então, as placas foram lavadas 3 vezes com tampão fosfato (PBS) com 0,05\% de Tween 20, $\mathrm{pH} 7,4$.

As amostras foram diluídas em PBS - Tween com 5\% de leite desnatado pH 7,4 na proporção 1/400 para lgG e 1/100 para $\lg M$.

As placas foram incubadas durante 1 hora. Lavou-se as placas 3 vezes, e adicionou-se $100 \mu \mathrm{l} /$ poço de anti-lgM ou anti-IgG humano conjugado à enzima fosfatase alcalina (Sigma), diluído 1/1000 em PBS-

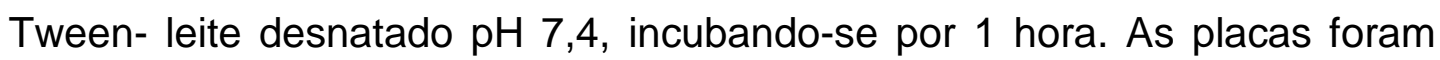
lavadas novamente 3 vezes como descrito acima e adicionou-se $100 \mu$ por poço de substrato p-nitro-fenil-fosfato na concentração de $1 \mathrm{mg} / \mathrm{mL}$ diluído em tampão glicina pH 10,5 para leitura em espectrofotômetro para ELISA (Labsystems Multiskan MS) em comprimento de onda de $405 \mathrm{~nm}$.

\subsection{Detecção de anticorpos anti Mycoplasma pneumoniae pelo método imunoenzimático (ELISA)}


Foram utilizados kits ImumnoWELLTM - Mycoplasma pneumoniae antibody (IgG e IgM) da GenBio (San Diego, CA), para realização deste procedimento.

Toda a metodologia seguiu os padrões recomendados pelo fabricante do kit.

4.8. Detecção de anticorpos anti Chlamydia spp pelo método de imunofluorescência indireta (IFI)

Foram utilizados kits de Imunofluorescência Indireta - Chlamydia Antibody Test System (IgG e IgM) da Bion Enterprises (USA) para a realização destes ensaios.

A metodologia seguiu os padrões citados no manual do fabricante do kit.

\subsection{Cultura de células endoteliais}

Linhagens de células HUV-EC-C (Umbilical cord, human - ATCC CRL 1730), foram cultivadas em garrafas de 25 $\mathrm{cm}^{2}$ contendo meio 199 (GIBCO $\mathrm{BRL}$ ), suplementado com $10 \%$ de soro fetal bovino inativado, $1 \%$ penicilina + estreptomicina. Logo após a confluência foi adicionado $1 \mathrm{ml}$ de cultura de sangue de paciente inoculada em SP-4 por 72 horas. Após 24 horas dessa 
inoculação, foi realizada a troca do meio (meio 199 suplementado com 10\% de soro fetal bovino inativado - sem antibiótico). Essa cultura de células foi mantida por 10 dias em estufa de CO2, fazendo-se a manutenção através da troca do meio de cultivo.

Após esse período, as células foram tripsinizadas. A seguir adicionouse meio 199 (GIBCO BRL) com 20\% de soro fetal bovino para bloquear a ação da tripsina. Posteriormente, as células foram lavadas com PBS. Uma alíquota dessas células (aproximadamente $1 \mathrm{ml}$ ) foi enviada para a microscopia eletrônica em glutaraldeído $2 \%$ na proporção 1:1, no intuito de verificar se as células endoteliais foram infectadas pelos micro-organismos.

\subsection{Coloração de Borrelia burgdorferi cultivadas em meios BSK e SP-4 modificado}

Estes experimentos tiveram como objetivo verificar se a $B$. burgdorferi cepa G39/40 de origem americana, seria capaz de sobreviver em meio SP-4, teoricamente inadequado para o seu desenvolvimento, analisando-se o seu crescimento e mudanças morfológicas e tintoriais. Algumas amostras de sangue de pacientes do grupo A foram semeadas em meio de cultura BSK ideal para crescimento de $B$. burgdorferi sensu lato e em meio SP-4 e coradas por diferentes metodologias. 


\subsubsection{Acridine orange}

Borrelia burgdorferi cepa G39/40 de origem americana, conservada congelada em nitrogênio líquido foi inoculada em meio BSK e, após crescimento, uma lâmina desta cultura foi preparada, deixando-a secar em temperatura ambiente e, posteriormente, a mesma foi fixada com etanol absoluto gelado por 10 minutos. Após terem sido fixadas, colocou-se uma gota da seguinte solução:

- Acridine orange (1X) em PBS (1:150)

Adicionou-se $10 \mu \mathrm{l}$ de Azul de Evans (10mg) em $100 \mu \mathrm{l}$ da solução preparada $\operatorname{acima}(1: 10)$.

Colocou-se esta solução final sobre a lâmina, cobriu-se com uma lamínula, levando-a em seguida para leitura em microscópio de fluorescência.

A cultura de $B$. burgdorferi semeada em meio SP-4 foi realizada da mesma forma e a coloração seguiu o mesmo procedimento acima.

\subsubsection{Panótico}

As lâminas foram preparadas conforme procedimento descrito anteriormente para a coloração com Acridine orange. Após a secagem em temperatura ambiente, procedeu-se a coloração conforme instruções do fabricante do kit Panótico Rápido (Laborclin). 


\subsection{Extração de DNA}

Para facilitar e agilizar as extrações de DNA das amostras de sangue total, foram utilizados os kits comerciais DNeasy ${ }^{\circledR}$ Blood \& Tissue Kit (Qiagen $\mathrm{GmbH}$ ) para pequenos volumes (até $200 \mu \mathrm{l}$ ) e o QIAamp ${ }^{\circledR}$ DNA Blood Midi Kit (Qiagen $\mathrm{GmbH}$ ), para volumes maiores (até $2 \mathrm{~mL}$ ). Os procedimentos seguiram as recomendações do fabricante.

\subsection{PCR}

\subsubsection{Gradientes}

Gradientes de temperatura foram realizados para determinar a temperatura ideal de anelamento das amostras em todos os primers utilizados.

\subsubsection{Primers e ciclos de temperatura}

4.12.2.1. Borrelia spp (gene FlaB - flagelina) (Stromdahl et al., 2003)

Para a reação num volume final de $50 \mu$ foram utilizados $5 \mu l$ da amostra de DNA extraído, $2 \mu \mathrm{l}$ de cada primer $(1.0 \mu \mathrm{M}), 5 \mu \mathrm{l}$ Tris- $\mathrm{HCl}(10 \mathrm{mM})$, 
$3 \mu \mathrm{l} \mathrm{MgCl} 2$ (1.5 mM), $8 \mu \mathrm{l}$ dNTP $\operatorname{mix}(1,25 \mathrm{mM}), 0.25 \mu \mathrm{l}$ TaqDNA polimerase (1.5U) e $24,75 \mu \mathrm{l}$ de $\mathrm{H}_{2} \mathrm{O}$ Milli $Q$.

FLA LL (5’- ACA TAT TCA GAT GCA GAC AGA GGT - 3’)

FLA RL (5'-GCA ATC ATA GCC ATT GCA GAT TGT - 3')

Para Borrelia spp (gene flagelina), os ciclos de temperatura e tempo para a reação consistiram em uma desnaturação inicial por 3 minutos a 95ํㅡ, seguida de 40 ciclos, cada um consistindo em uma desnaturação a $95^{\circ} \mathrm{C}$ por 1 minuto, anelamento a $65^{\circ} \mathrm{C}$ por 1 minuto (obtido após gradiente de temperatura) e extensão a $75^{\circ} \mathrm{C}$ por 1 minuto.

4.12.2.2. Borrelia spp (gene 16S rRNA) ( baseado no trabalho de Rich et al., 2001).

Para a reação num volume final de $50 \mu$ foram utilizados $5 \mu l$ da amostra de DNA extraído, $2 \mu$ l de cada primer $(1.0 \mu \mathrm{M}), 5 \mu \mathrm{l}$ Tris- $\mathrm{HCl}(10 \mathrm{mM})$, $3 \mu \mathrm{l} \mathrm{MgCl} 2(1.5 \mathrm{mM}), 8 \mu \mathrm{l}$ dNTP $\operatorname{mix}(1,25 \mathrm{mM}), 0.4 \mu \mathrm{l}$ TaqDNA polimerase (2U) e 24,6ul de $\mathrm{H}_{2} \mathrm{O}$ Milli Q.

Iniciadores para amplificação parcial do gene 16S rRNA

16borTF ( 5' - GAG TCT GCG TCT TAT TAG CTA - 3')

16borTR (5' - AAC AAG GGT TGC GCT CGT TG - 3’) 
Para Borrelia (gene 16S rRNA), os ciclos de temperatura e tempo para a reação consistiram em uma desnaturação inicial por 3 minutos a 94ํㅡ, seguida de 35 ciclos, cada um consistindo em uma desnaturação a $94^{\circ} \mathrm{C}$ por 1 minuto, anelamento a $68^{\circ} \mathrm{C}$ por 1 minuto e extensão a $72^{\circ} \mathrm{C}$ por 1 minuto e 30 segundos.

4.12.2.3. Chlamydia spp (Messmer et al., 1997)

Para a reação num volume final de $50 \mu$ foram utilizados $5 \mu \mathrm{l}$ da amostra de DNA extraído, $1 \mu$ l de cada primer $(0.2 \mu \mathrm{M}), 5 \mu \mathrm{l}$ Tris- $\mathrm{HCl}(10 \mathrm{mM})$, $3 \mu \mathrm{l} \mathrm{MgCl} 2$ (2.5 mM), $8 \mu \mathrm{l}$ dNTP $\operatorname{mix}(1,25 \mathrm{mM}), 0.25 \mu \mathrm{l}$ TaqDNA polimerase (1.25U) e $26,75 \mu$ lde $\mathrm{H}_{2} \mathrm{O}$ Milli $Q$.

\section{Chlamy 1 (5'- ACG GAA TAA TGA CTT CGG - 3') \\ Chlamy 2 (5'- TAC CTG GTA CGC TCA ATT - 3')}

Para Chlamydia spp, os ciclos de temperatura e tempo da reação consistiram em uma desnaturação inicial por 2 minutos a $95^{\circ} \mathrm{C}$, seguida de 35 ciclos, cada um consistindo em uma desnaturação a $94^{\circ} \mathrm{C}$ por 1 minuto, anelamento a $54^{\circ} \mathrm{C}$ por 30 segundos (obtido após gradiente de temperatura) e extensão a $72^{\circ} \mathrm{C}$ por 1 minuto.

4.12.2.4. Mycoplasma spp (Smith et al., 2004) 
Para a reação num volume final de $50 \mu$ foram utilizados $5 \mu \mathrm{l}$ da amostra de DNA extraído, $2,5 \mu \mathrm{l}$ de cada primer $(0.5 \mu \mathrm{M}), 5 \mu \mathrm{l}$ Tris- $\mathrm{HCl}$ (10mM), $1,5 \mu \mathrm{l} \mathrm{MgCl} 2(1.5 \mathrm{mM}), 8 \mu \mathrm{l} \mathrm{dNTP} \operatorname{mix}(1,25 \mathrm{mM}), 0.4 \mu \mathrm{l}$ TaqDNA polimerase (2U) e 25,1 $\mu$ l de $\mathrm{H}_{2} \mathrm{O}$ Milli $\mathrm{Q}$.

$$
\begin{aligned}
& \text { Myco - F (5’- GGG AGC AAA CAG GAT TAG ATA CCC T - 3’) } \\
& \text { Myco - R (5'- TGC ACC ATC TGT CAC TCT GTT AAC CTC - 3’) }
\end{aligned}
$$

Para Mycoplasma spp, os ciclos de temperatura e tempo da reação consistiram em uma desnaturação inicial por 4 minutos a $95^{\circ} \mathrm{C}$, seguida de 40 ciclos, cada um consistindo em uma desnaturação a $94^{\circ} \mathrm{C}$ por 45 segundos, anelamento a $64^{\circ} \mathrm{C}$ por 1 minuto (obtido após gradiente de temperatura) e extensão a $72^{\circ} \mathrm{C}$ por 2 minutos.

4.12.2.5. Mollicutes (Cordova e Cunha et al., 2002)

Para a reação num volume final de $50 \mu$ foram utilizados $5 \mu$ da amostra de DNA extraído, $2 \mu$ de cada primer $(0.3 \mu \mathrm{M}), 5 \mu \mathrm{l}$ Tris- $\mathrm{HCl}(10 \mathrm{mM})$, $3 \mu \mathrm{l} \mathrm{MgCl} 2(2.5 \mathrm{mM}), 8 \mu \mathrm{l}$ dNTP $\operatorname{mix}(1,25 \mathrm{mM}), 0.2 \mu \mathrm{l}$ TaqDNA polimerase (1U) e 24,8 $\mu$ l de $\mathrm{H}_{2} \mathrm{O}$ Milli $Q$.

$$
\begin{aligned}
& \text { MGSO (5'-TGC ACC ATC TGT CAC TCT GTT AAC CTC - 3') } \\
& \text { GPO1 (5'- ACT CCT ACG GGA GGC AGC CGTA - 3') }
\end{aligned}
$$


Para Mollicutes, os ciclos de temperatura e tempo da reação consistiram em uma desnaturação inicial por 5 minutos a $95^{\circ} \mathrm{C}$, seguida de 30 ciclos, cada um consistindo em uma desnaturação a 95ำ por 30 segundos, anelamento a $66^{\circ} \mathrm{C}$ por 1 minuto e 30 segundos (obtido após gradiente de temperatura) e extensão a $72^{\circ} \mathrm{C}$ por 1 minuto e 30 segundos.

4.12.2.6. Plasmídeos Ip25 e Ip28-1 (lyer et al., 2003)

Para a reação num volume final de $50 \mu$ foram utilizados $5 \mu l$ da amostra de DNA extraído, $6 \mu$ de cada primer (10pmoles), $5 \mu$ l Tris-HCl (10mM), 1,5 $\mu \mathrm{l} \mathrm{MgCl2} \mathrm{(2.5} \mathrm{mM),} \mathrm{1,25 \mu l} \mathrm{dNTP} \mathrm{mix} \mathrm{(10mM),} \mathrm{0.25 \mu l} \mathrm{TaqDNA}$ polimerase e $25 \mu \mathrm{l}$ de $\mathrm{H}_{2} \mathrm{O}$ Milli Q.

$$
\begin{aligned}
& \text { Ip25a (5'- AGAATTATGTCGGTGGCGTTGT - 3') } \\
& \text { Ip25b (5'-ATTAAAGCCGCCTTTTCCTTGGT -3') } \\
& \text { Ip28-1c (5'- AGTAGTACGACGGGGAAACCA - 3') } \\
& \text { Ip28-1d (5'- ACTTTGCGAACTGCAGAC - 3') }
\end{aligned}
$$

Para Ip25, os ciclos de temperatura e tempo da reação consistiram em uma desnaturação inicial por 2 minutos a $94^{\circ} \mathrm{C}$, seguida de 35 ciclos, cada um consistindo em uma desnaturação a $94^{\circ} \mathrm{C}$ por 30 segundos, anelamento a $67^{\circ} \mathrm{C}$ por 30 segundos (obtido após gradiente de temperatura) e extensão a $72^{\circ} \mathrm{C} 30$ segundos. 
Para Ip28-1, os ciclos de temperatura e tempo da reação consistiram em uma desnaturação inicial por 2 minutos a $94^{\circ} \mathrm{C}$, seguida de 35 ciclos, cada um consistindo em uma desnaturação a $94^{\circ} \mathrm{C}$ por 30 segundos, anelamento a 59,5ํ $\mathrm{C}$ por 30 segundos (obtido após gradiente de temperatura) e extensão a $72^{\circ} \mathrm{C} 30$ segundos.

4.12.2.7. Plasmídeos cp32-4 e cp32-2/7 (lyer et al., 2003)

Para a reação num volume final de $50 \mu$ foram utilizados $5 \mu$ da amostra de DNA extraído, $6 \mu$ de cada primer (10pmoles), $5 \mu$ Tris-HCl

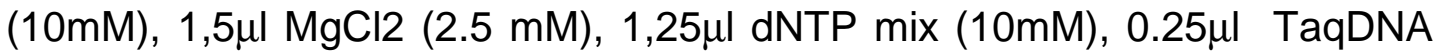
polimerase e $25 \mu \mathrm{l}$ de $\mathrm{H}_{2} \mathrm{O}$ Milli Q.

$$
\begin{aligned}
& \text { cp32-4a (5'- AGATCCTCAAAATAGTTTAACCAG - 3’) } \\
& \text { cp32-4b (5'- TTAATATTGGCAGAGAGTCTACAG - 3') } \\
& \text { cp32-2/7a (5' - GGAATGTATTAATTGATAATTCAG - 3') } \\
& \text { cp32-2/7b (5' - GCGAAATAAATAGTGCCTTATGGG-3') }
\end{aligned}
$$

Para cp32, os ciclos de temperatura e tempo da reação consistiram em uma desnaturação inicial por 2 minutos a 95으, seguida de 35 ciclos, cada um consistindo em uma desnaturação a $94^{\circ} \mathrm{C}$ por 30 segundos, anelamento a $52^{\circ} \mathrm{C}$ por 30 segundos (obtido após gradiente de temperatura) e extensão a $72^{\circ} \mathrm{C} 30$ segundos. 
4.12.2.8. Borrelia spp (gene flgE - gancho flagelar) (baseado em Sal et al., 2008)

Para a primeira reação num volume final de $50 \mu$, foram utilizados $5 \mu \mathrm{l}$ da amostra de DNA extraído, $2 \mu$ de cada primer (5pmoles), $5 \mu$ l Tris- $\mathrm{HCl}$ (10mM), $3 \mu \mathrm{l} \mathrm{MgCl} 2(1.5 \mathrm{mM}), 8 \mu \mathrm{l}$ dNTP mix $(1,25 \mathrm{mM}), 0.25 \mu \mathrm{l}$ TaqDNA polimerase (1.5U) e $24,75 \mu \mathrm{l}$ de $\mathrm{H}_{2} \mathrm{O}$ Milli Q. Adicionou-se $1,5 \mu \mathrm{l}$ de DMSO por amostra (concentração final 3\%). Para a segunda reação (PCR/PCR), utilizou-se $0,5 \mu$ l do produto da $1^{\underline{a}}$ reação, $2 \mu$ l de cada primer (5pmoles), $5 \mu l$ Tris- $\mathrm{HCl}(10 \mathrm{mM}), 3 \mu \mathrm{l} \mathrm{MgCl} 2(1.5 \mathrm{mM}), 8 \mu \mathrm{l}$ dNTP mix $(1,25 \mathrm{mM}), 0.25 \mu \mathrm{l}$ TaqDNA polimerase (1.5U) e 29,25 $\mu \mathrm{l}$ de $\mathrm{H}_{2} \mathrm{O}$ Milli Q. Adicionou-se $1,5 \mu \mathrm{l}$ de DMSO por amostra (concentração final 3\%).

flgE 470 FW (5'- CGCCTATTCTAACTTGACCCGAAT - 3')

flgE 470 Rev (5'- TTAGTGTTCTTGAGCTTAGAGTTG - 3')

Para este primer, os ciclos de temperatura e tempo para a reação consistiram em uma desnaturação inicial por 3 minutos a 95ํㅡ, seguida de 40 ciclos, cada um consistindo em uma desnaturação a 95ํㅡ por 45 segundos, anelamento a $64^{\circ} \mathrm{C}$ por 45 segundos e extensão a $72^{\circ} \mathrm{C}$ por 45 segundos.

Para todas as reações, independente do primer, foi utilizado um controle positivo (DNA do micro-organismo) e um controle negativo (mix). $\mathrm{O}$ 
produto final das reações foi analisado em gel de agarose, corado por $\mathrm{SYBr}$ Gold (Invitrogen) e visualizado à trans-iluminação pela ultravioleta.

\subsection{Sequenciamento}

As amostras que apresentaram positividade nas reações de PCR foram purificadas com O QIAEX®II Gel Extraction Kit (Qiagen $\mathrm{GmbH}$ ) e o sequenciamento foi realizado com o BigDye Terminator Cycle Sequencing kit, version 3.1 (Applied Biosystems), e analisado pelo ABI Prism 3730 DNA analyzer (Applied Biosystems). As sequências obtidas foram submetidas à análise utilizando o Basic Local Alignment Search Tool (BLAST - NCBI) (Altschul et al., 1990). 
5. Resultados 


\subsection{Sorologia para Borrelia burgdorferi}

\subsubsection{Grupo A}

Das 68 amostras de soros de pacientes com SBY do grupo A, analisadas pelo método de ELISA, $23(33,8 \%)$ foram positivas. Foram submetidas também ao teste 50 amostras de indivíduos normais, sendo que $6(12 \%)$ foram consideradas positivas.

Pelo método de WB, das 68 amostras de pacientes com SBY, 40 $(58,8 \%)$ foram consideradas positivas. Das 50 amostras de indivíduos normais que realizaram WB, apenas 06 foram positivas (12\%). A partir dos resultados obtidos, das 68 amostras de pacientes com SBY, 44 (64,7\%) tiveram sorologia positiva (ELISA ou WB) para B. burgdorferi. Das 50 amostras oriundas de indivíduos normais, 8 (16\%) foram consideradas positivas (ELISA e WB), diferença estatisticamente significante pelo teste de t-Student ( $P<0,05)$ (intervalo de confiança de 95\%). A análise estatística foi realizada pelo programa SPSS 14.0 for Windows.

Confirmou-se a baixa sensibilidade dos testes sorológicos, em torno de $65 \%$, mesmo com a inclusão dos dois métodos laboratoriais (ELISA e WB) em conjunto, e que, a especificidade dos ensaios, quando calculada baseada em indivíduos normais, que não frequentavam áreas de risco foi de $84 \%$ 


\subsubsection{Grupo B}

Das 10 amostras de soros de pacientes com SBY do grupo B, analisadas pelo método de ELISA, nenhuma apresentou positividade. Já pelo método de WB, 4 (40\%) foram consideradas positivas.

\subsection{Sorologia para Mycoplasma pneumoniae (ELISA)}

Das 68 amostras dos pacientes com diagnóstico de SBY do grupo A, $31(45,6 \%)$ foram consideradas positivas, e das 50 amostras de indivíduos normais, 21 (42\%) foram positivas. Estes dados indicam que a frequência de positividade de anticorpos para $M$. pneumoniae foi semelhante nos dois grupos, confirmado estatisticamente pelo teste t-student ( $\mathrm{P}>0,05$ )(intervalo de confiança de 95\%). A análise estatística foi realizada pelo programa SPSS 14.0 for Windows.

\subsection{Sorologia para Chlamydia spp (IFI)}

Das 68 amostras de pacientes com SBY do grupo A, 56 (82,35\%) foram consideradas positivas para anticorpos da classe IgG (Figura 1). Das 50 amostras de indivíduos normais, 44 (88\%) foram positivas. A análise estatística realizada pelo teste t-Student, mostrou-se não significante 
$(P>0,05)$ (intervalo de confiança de 95\%). A análise estatística foi realizada pelo programa SPSS 14.0 for Windows.

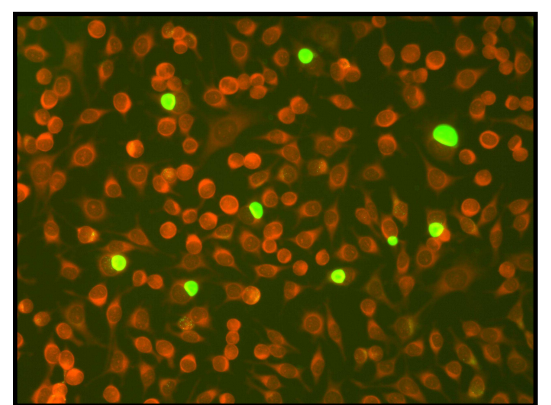

Controle Positivo

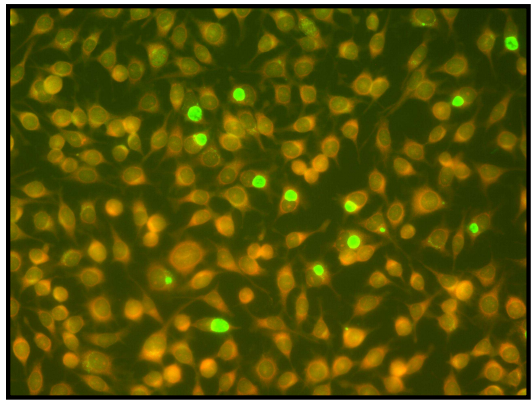

$1: 40$

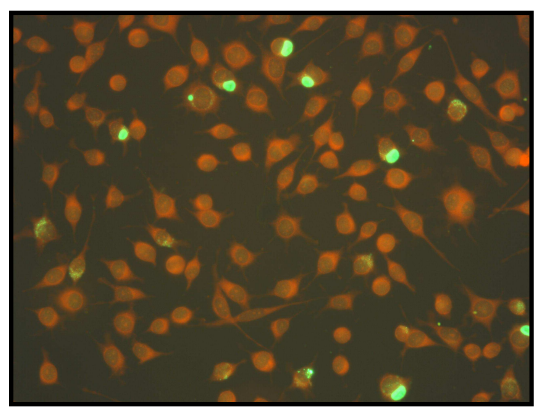

$1: 640$

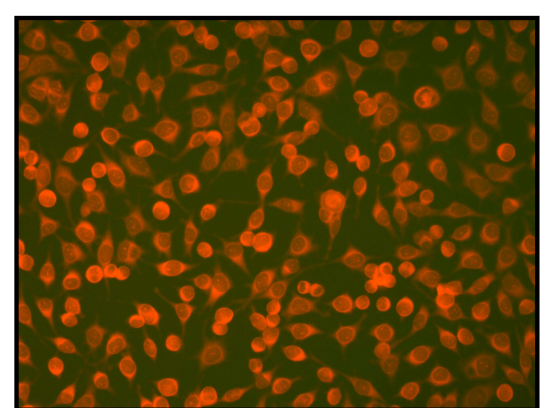

Controle neqativo

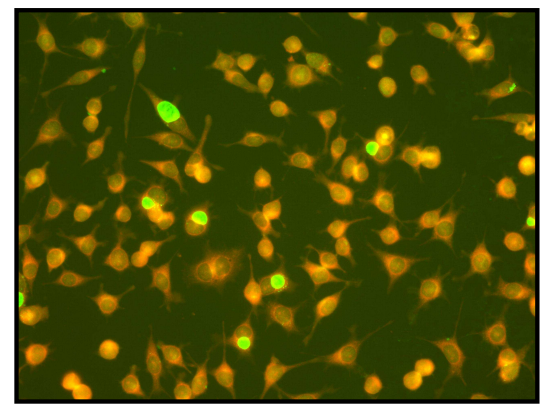

$1: 160$

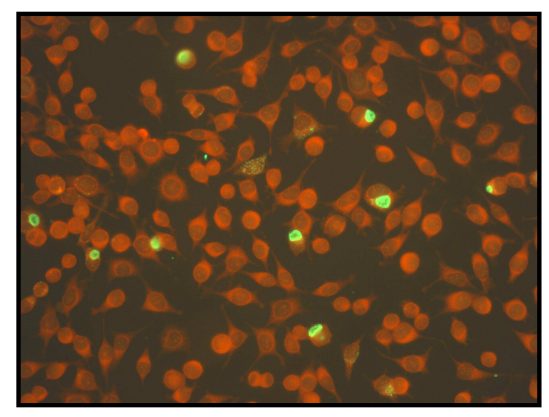

$1: 2560$

Figura 1 - Imunofluorescência Indireta para Chlamydia spp realizada com soro de paciente SBY $(\lg G)(400 X)$

\subsection{Microscopia de campo escuro}


Foram analisadas 52 amostras de sangue de pacientes com SBY do grupo A ao microscópio de campo escuro, dos quais 49 (94,2\%) foram consideradas positivas, apresentando estruturas sugestivas de espiroquetas.

Das 50 amostras de indivíduos normais, 10 (20\%) apresentaram espiroquetídeos, e esta diferença foi estatisticamente significante pelo teste t-Student, $(P<0,05)$ (intervalo de confiança de 95\%). A análise estatística dos foi realizada pelo programa SPSS 14.0 for Windows.

\subsection{Cultura de espiroquetídeos visualizados no sangue em meio SP-4}

As amostras de sangue provenientes de pacientes com SBY foram selecionadas através da análise em microscopia de campo escuro, sendo que ao apresentar uma quantidade significativa de espiroquetídeos, a amostra foi semeada em meio SP-4.

Das 68 amostras de pacientes com SBY do grupo A, foram selecionadas 19 amostras mais ricas em espiroquetídeos identificados à microscopia de campo escuro, e que foram semeadas em meio SP-4. Em 14 amostras $(73,7 \%)$ houve crescimento de estruturas após 72 horas de cultivo, visualizada em microscopia de campo escuro (Figura 2). 


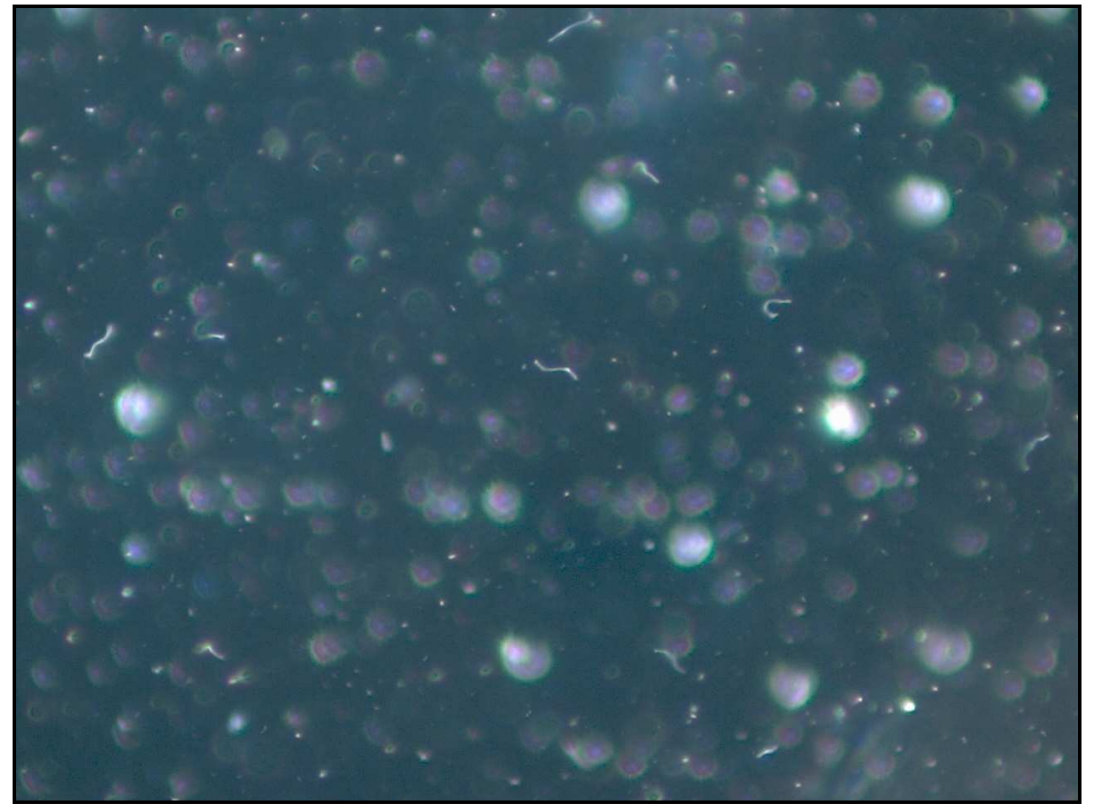

Figura 2 - Cultura de sangue total de paciente com SBY inoculado em meio SP-4. Observa-se o crescimento de espiroquetídeos. Visualização em microscopia de campo escuro. Aumento 1000X.

\subsection{Microscopia eletrônica}

Foram analisadas à microscopia eletrônica, amostras de 08 pacientes com diagnóstico de SBY do grupo A. Incluiu-se ainda, amostras de 01 indivíduo normal, 03 controles de células endoteliais, 01 amostra de $B$. burgdorferi cultivada em meio SP-4 e 01 amostra de $B$. burgdorferi cultivada em meio BSK. As amostras selecionadas para análise à microscopia eletrônica, apresentavam-se ricas em espiroquetídeos no sangue periférico ou em culturas no meio SP-4.

A primeira amostra escolhida foi proveniente de $1 \mathrm{ml}$ de sangue total de paciente com SBY, que apresentava grande quantidade de estruturas à microscopia de campo escuro. Na microscopia eletrônica, visualizaram-se 
estruturas sugestivas de Chlamydia spp, Mycoplasma spp, espiroquetas e Archaebacteria spp (Figura 3).

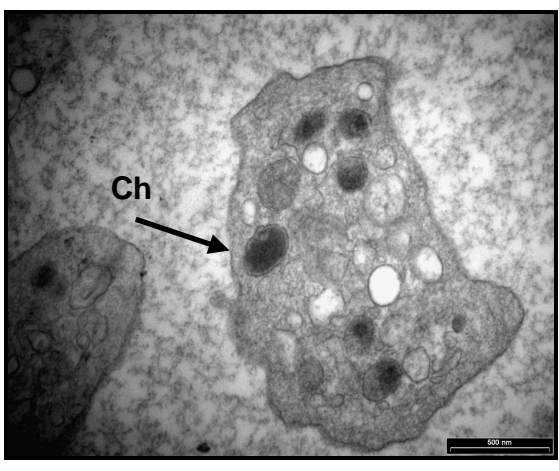

A

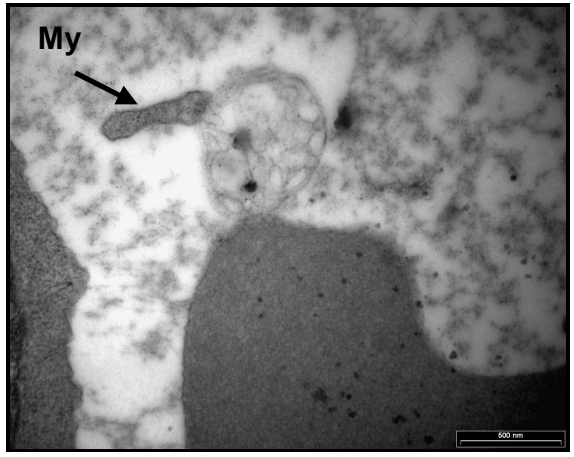

C

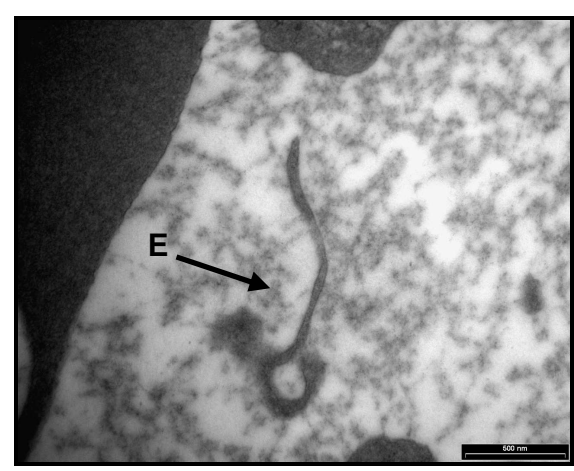

B

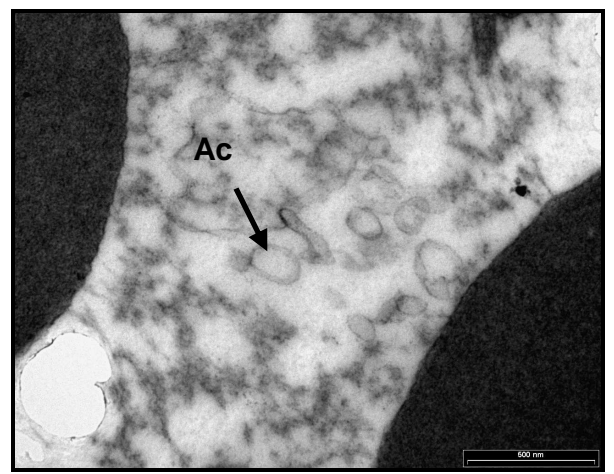

D

Figura 3 - Amostra de sangue periférico de paciente com SBY, analisada à ME onde observa-se estruturas semelhantes a Chlamydia spp (Ch), espiroquetas (E), Mycoplasma spp (My) e Archaebacteria spp (Ac). Aumento de 24000X em A, B e C e 30000X em D.

A segunda e terceira amostras foram provenientes do cultivo de $1 \mathrm{ml}$ de sangue total de pacientes com SBY, semeados em meio SP-4 e mantidos por três dias. Utilizou-se alíquotas de $1 \mathrm{ml}$ da bactéria em suspensão neste 
meio para análise à microscopia eletrônica. Houve identificação de estruturas sugestivas de espiroquetas e Mycoplasma spp na segunda amostra (Figuras 4 e 5), assim como na terceira amostra (Figuras 6 e 7 ).

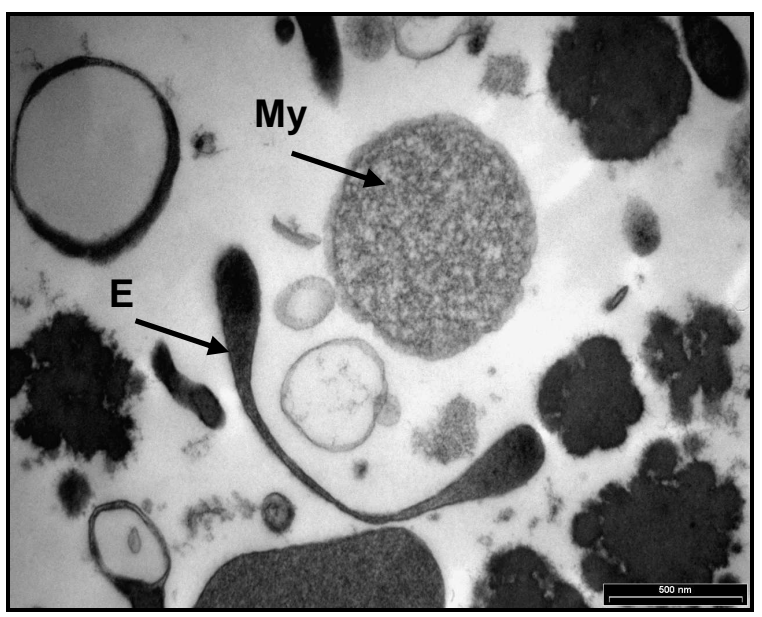

Figura 4 - Amostra de sangue periférico de paciente com SBY inoculado em meio SP-4, e analisado a ME, onde observa-se estruturas semelhantes a espiroqueta (E) e Mycoplasma spp (My). Aumento de 24000X.

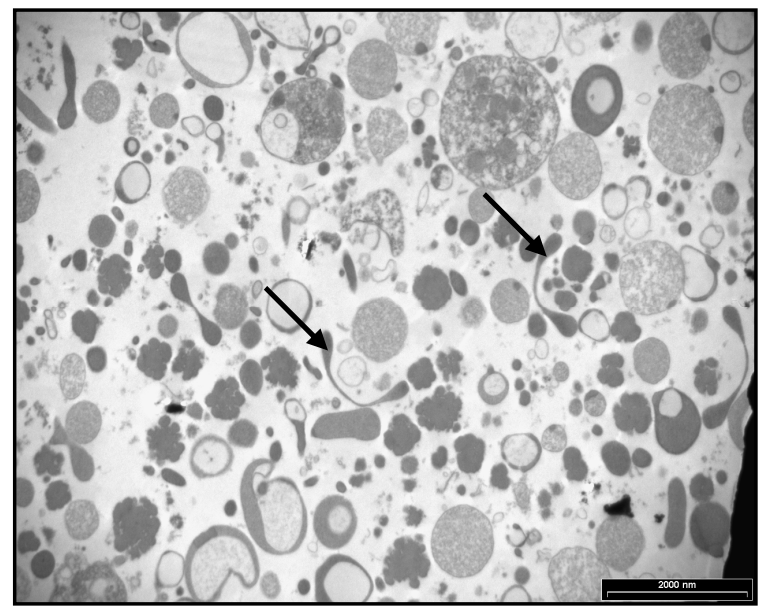

Figura 5 - Amostra de sangue periférico de paciente com SBY inoculado em meio SP-4, e analisado à ME onde observa-se estruturas semelhantes a espiroquetas. Aumento de 6200X. 


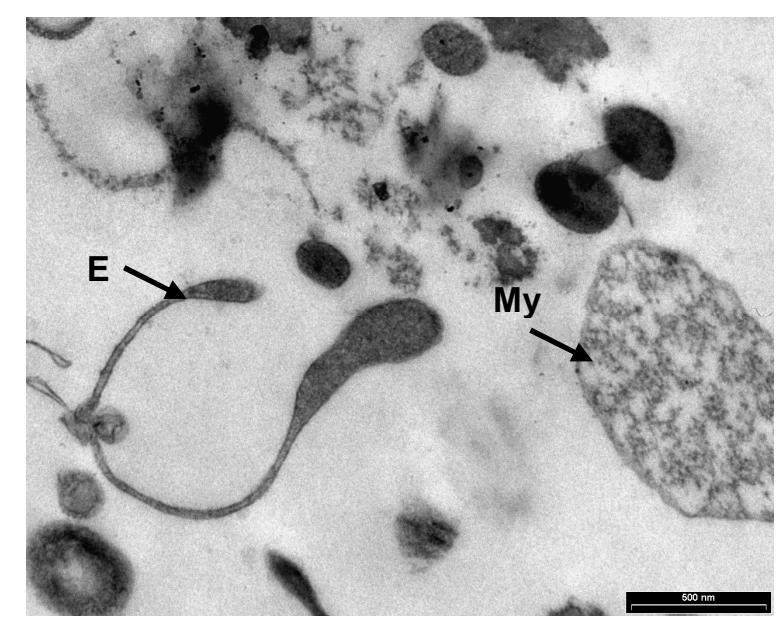

Figura 6 - Amostra de sangue periférico de paciente com SBY inoculado em meio SP-4, e analisado à ME onde observa-se estruturas semelhantes a espiroqueta (E) e Mycoplasma spp (My). Aumento de 24000X.

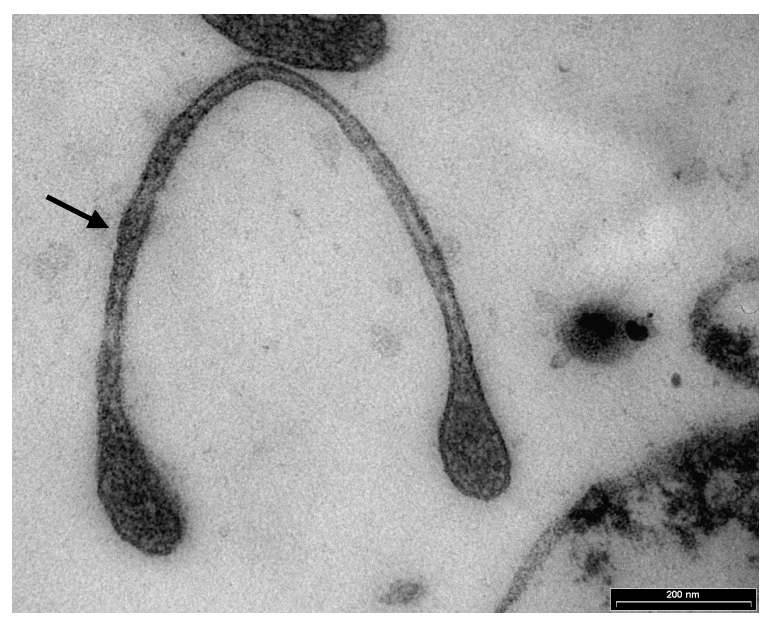

Figura 7 - Amostra de sangue periférico de paciente com SBY inoculado em meio SP-4, e analisado à ME onde observa-se estrutura semelhante a espiroqueta. Aumento de 65000X.

A quarta amostra também foi proveniente do cultivo de $1 \mathrm{ml}$ sangue total de paciente com SBY, semeado em meio SP-4 por três dias. Utilizou-se uma alíquota de $1 \mathrm{ml}$ do sobrenadante deste cultvivo para análise à microscopia eletrônica. Houve identificação de estruturas sugestivas de espiroquetas. 
A quinta e a sexta amostras enviadas à $\mathrm{ME}$, eram amostras de $1 \mathrm{ml}$ de plasmas, provenientes de dois pacientes com SBY. Entretanto nestes casos não houve identificação de micro-organismos, provavelmente devido ao tipo de material (plasma).

A sétima e a oitava amostras de sangue com espiroquetídeos foram empregadas para serem semeadas em cultivo de células endoteliais. Semeou-se inicialmente $1 \mathrm{ml}$ de sangue total de pacientes com SBY, contendo espiroquetídeos em meio SP-4, e após 3 dias, uma alíquota de 1 $\mathrm{ml}$ da suspensão contendo espiroquetídeos, foi adicionada em frascos de cultura contendo células endoteliais aderidas. Após 10 dias de incubação, as células endoteliais foram enviadas à microscopia eletrônica, quando se observou presença de espiroquetídeos no interior de células endoteliais da sétima amostra (Figura 8), enquanto a oitava foi negativa.

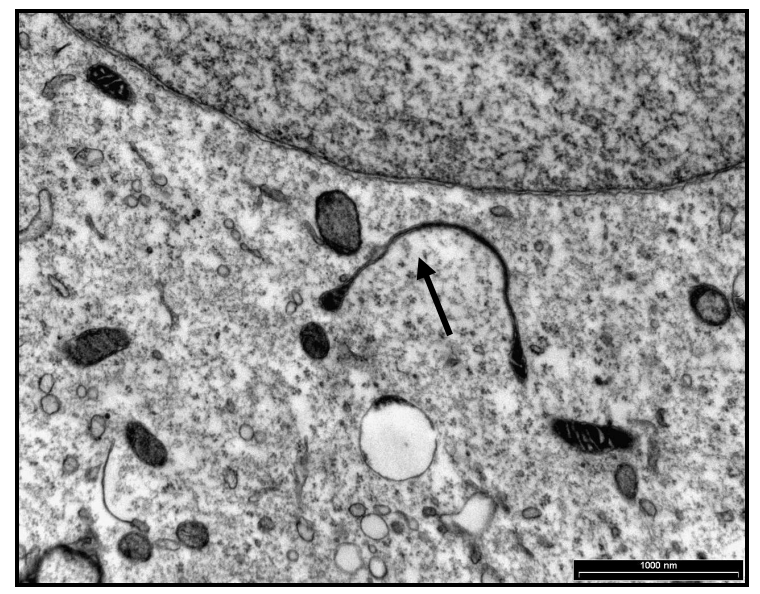

Figura 8 - Amostra de sangue periférico de paciente com SBY inoculado em meio SP-4, e posteriormente em células endoteliais. A análise à ME mostra o espiroquetídeo no interior da célula endotelial. Aumento de 15000X.

Foi inoculado também $1 \mathrm{ml}$ de sangue total de individuo controle normal, positivo à microscopia de campo escuro para a presença de 
espiroquetídeos em meio SP-4. Após 3 dias de cultivo, uma alíquota em suspensão foi colocada em cultura de células endoteliais. Após 10 dias a amostra foi encaminhada à microscopia eletrônica, e não foi visualizada a presença de estruturas no interior das células endoteliais.

Amostras controles de cultura de células endoteliais (sem inoculação de bactérias) foram mantidas em meio 199 durante 10 dias e depois encaminhadas à microscopia eletrônica. Não foi visualizado nenhum sinal de inclusão bacteriana nestas células.

Amostras de cultura de Borrelia burgdorferi também foram enviadas para análise ao microscópio eletrônico, sendo uma inoculada em meio SP-4 (Figura 9) e outra em BSK e posteriormente em células endoteliais (Figuras 10 e 11). As fotos mostram borrelias que perderam sua morfologia habitual espiralada, aparentemente sem flagelo, e outras morfologias que lembravam cistos.

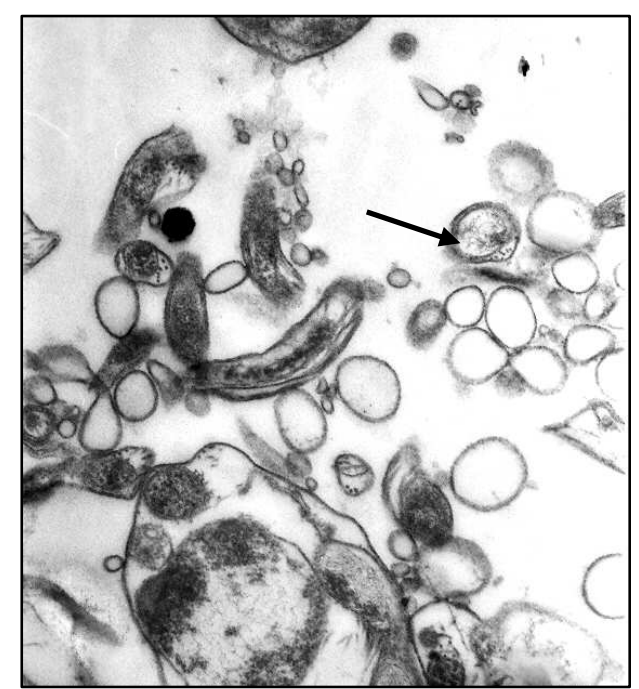

Figura 9 - Cultura de Borrelia burgdorferi inoculada inicialmente em meio SP4 por três dias e a seguir semeada em cultura de células endoteliais. Amostra de células endoteliais cultivadas por 26 dias e enviada à ME, exibe estruturas císticas. A cultura foi centrifugada para concentração dos microorganismos, antes do envio do material para análise à ME. Aumento de 10000X. 


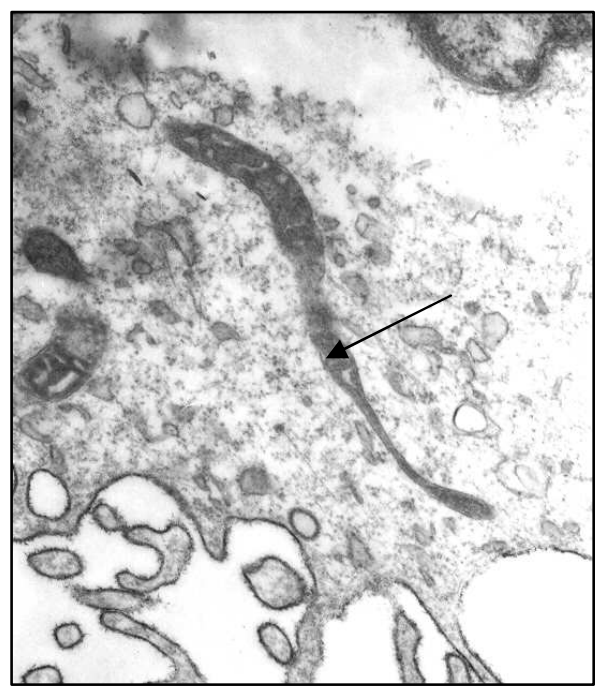

Figura 10 - Borrelia burgdorferi foi semeada em meio BSK e a seguir inoculada em cultura contendo células endoteliais. Amostras de células endoteliais foram coletadas após 3 dias e analisadas à ME, visualizando-se uma espiroqueta, com morfologia alterada (não espiralada) e aparentemente sem flagelos. Aumento de 7200X.

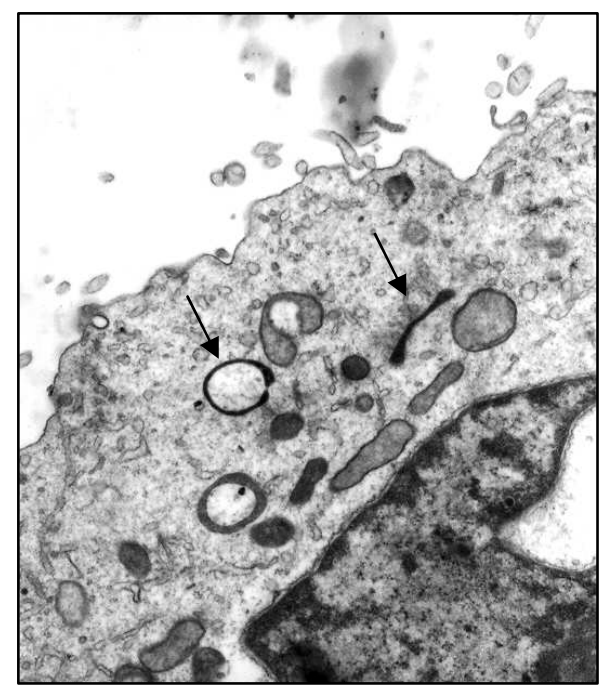

Figura 11 - Borrelia burgdorferi mantida em cultivo no meio BSK, a seguir inoculada em cultura de células endoteliais mantidas em meio 199. Após 3 dias, coletou-se amostras de células endoteliais que foram enviadas à ME, onde visualiza-se estruturas que sugerem espiroquetas não espiraladas com morfologia bacteroide e outras estruturas que lembram cistos. Aumento de 4200X.

\subsection{Coloração}




\subsubsection{Coloração de cultura de Borrelia burgdorferi em BSK com Acridine orange}

A cultura de B.burgdorferi realizada em meio BSK, próprio para cultivo desta, ao atingir seu nível de crescimento ideal, mostrou espiroquetas com a morfologia esperada, ou seja, espiraladas e longas, quando coradas com Acridine orange e Azul de Evans (Figura 12).

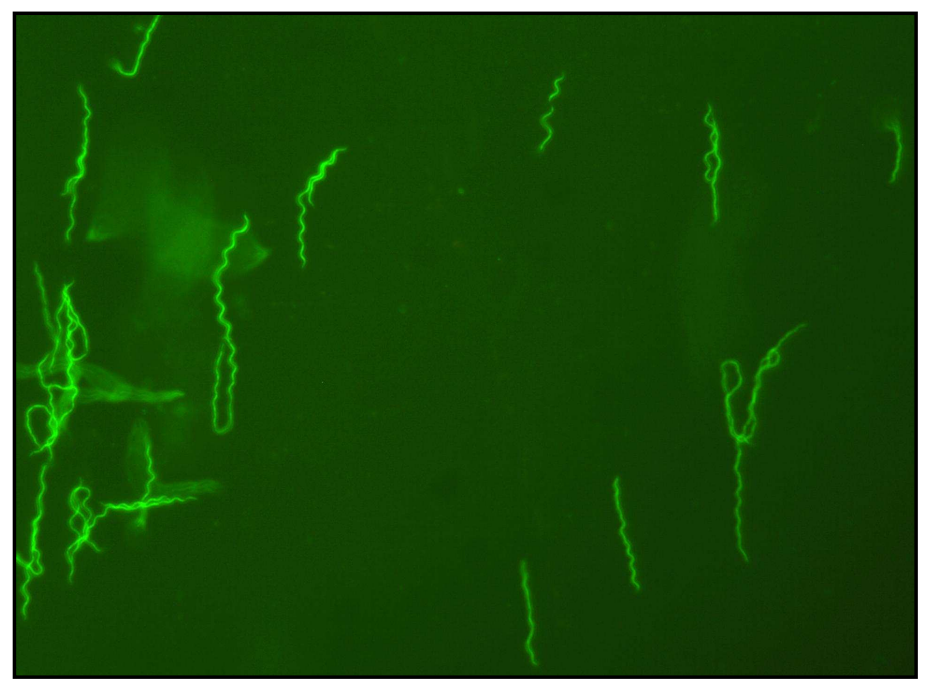

Figura 12 - Cultura de B. burgdorferi em meio BSK, corada com Acridine orange e Azul de Evans (1000X).

\subsubsection{Coloração de cultura de Borrelia burgdorferi semeada em meio SP-4 com Acridine orange}

Quando a B. burgdorferi foi semeada em meio SP-4 (modificado), não adequado ao desenvolvimento de borrelias, as bactérias cresceram pouco e houve mudança na morfologia das espiroquetas, que exibiram diferentes formas e tamanhos, algumas simulando cistos (Figura 13). 


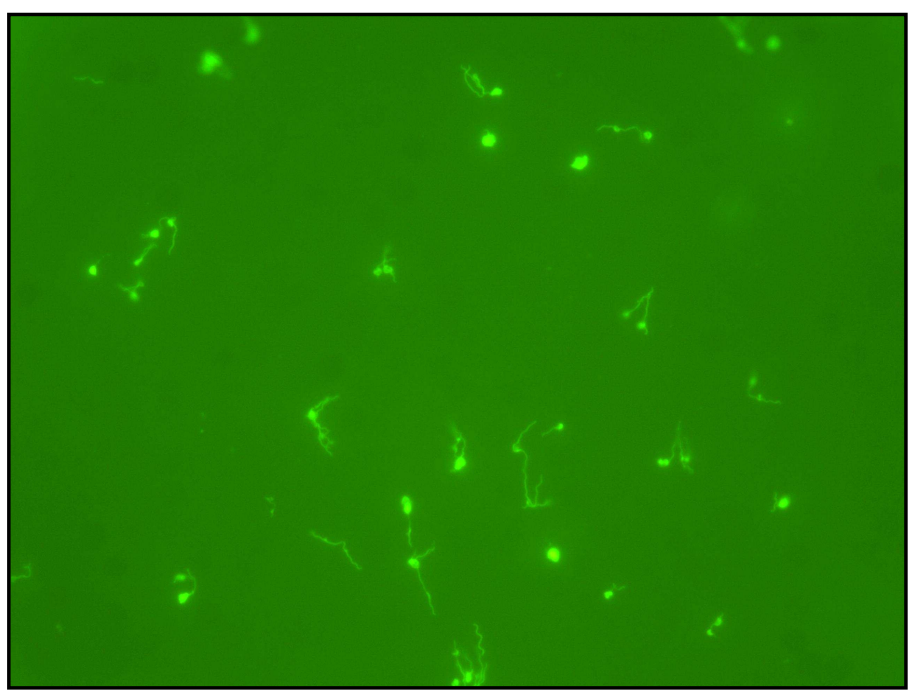

Figura 13 - Cultura de $B$. burgdorferi em meio SP-4, corada pelo método de Acridine orange e Azul de Evans (1000X).

5.7.3. Coloração da B. burgdorferi semeada em meio BSK pelo Panótico

Foi realizada a coloração da cultura de $B$. burgdorferi semeada em meio BSK com Panótico Rápido, que mostrou espiroquetas de morfologia preservada.

5.7.4. Coloração da B. burgdorferi semeada em meio SP-4 pelo Panótico 
Borrelia burgdorferi quando cultivada em meio SP-4 e corada pelo Panótico, mostra transformação de sua morfologia para formas atípicas, algumas simulando cistos (Figura 14).

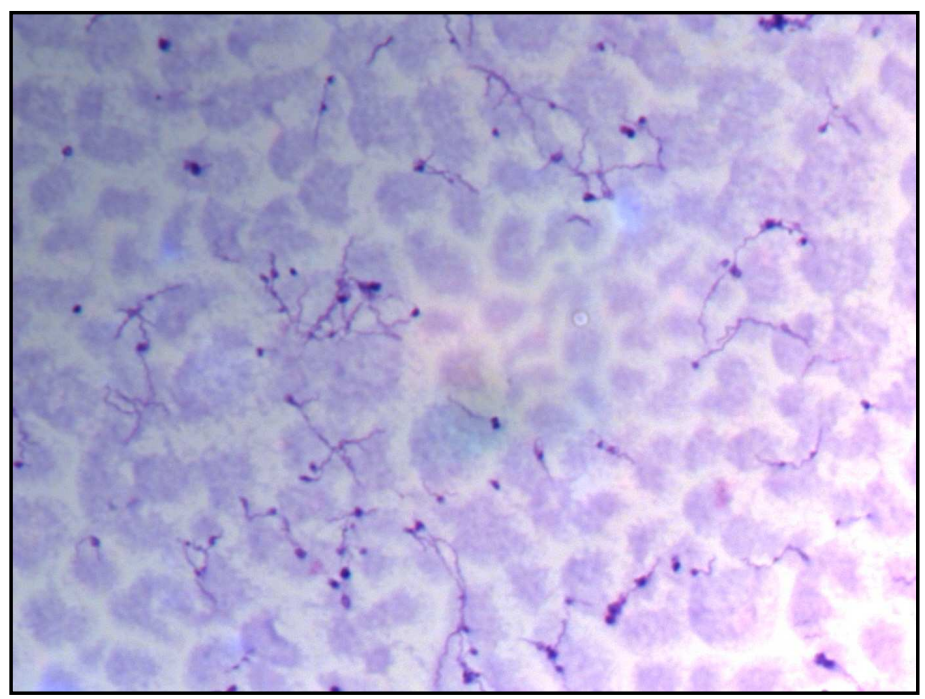

Figura 14 - Cultura de B. burgdorferi semeada em meio SP-4 e corada pelo Panótico (1000X).

5.7.5. Coloração pelos métodos de Panótico Rápido e Acridine orange dos espiroquetídeos visualizados em sangue de pacientes com SBY semeado em meio SP-4

Não houve sucesso na tentativa de coloração pelo método de Panótico Rápido das estruturas (espiroquetídeos) visualizadas através de MO no sobrenadante da cultura de sangue dos pacientes com SBY inoculadas em meio SP-4. 
Pelo método de Acridine orange, os resultados também não foram promissores. Raras estruturas sugestivas de cistos foram coradas.

\subsection{Biologia Molecular}

\subsubsection{PCR}

\subsubsection{Grupo A}

Das 68 amostras de pacientes com SBY do grupo A, 54 (79,4\%) tinham sangue total armazenado e, consequentemente, foram testadas com os primers: Borrelia spp (gene flagelina e 16S rRNA), Chlamydia spp, Mycoplasma spp e Mollicutes sendo que todas apresentaram-se negativas nestas reações. Das 50 amostras do grupo controle, 49 (98\%) foram testadas para os mesmos primers que o grupo de SBY, apresentando-se negativas também.

As reações de PCR que amplificam fragmentos dos genes dos plasmídeos Ip25 e Ip28-1 apresentaram-se negativas, tanto para o grupo SBY quanto para o grupo controle.

Com os primers para detecção de plasmídeos circulares $\mathrm{cp} 32,4$ das 54 amostras do grupo A (SBY) $(7,4 \%)$ foram positivas quando testadas com os primers cp32-2/7 e $9(16,6 \%)$ quando testadas com os primers cp $32-4$ (Figura 15). 


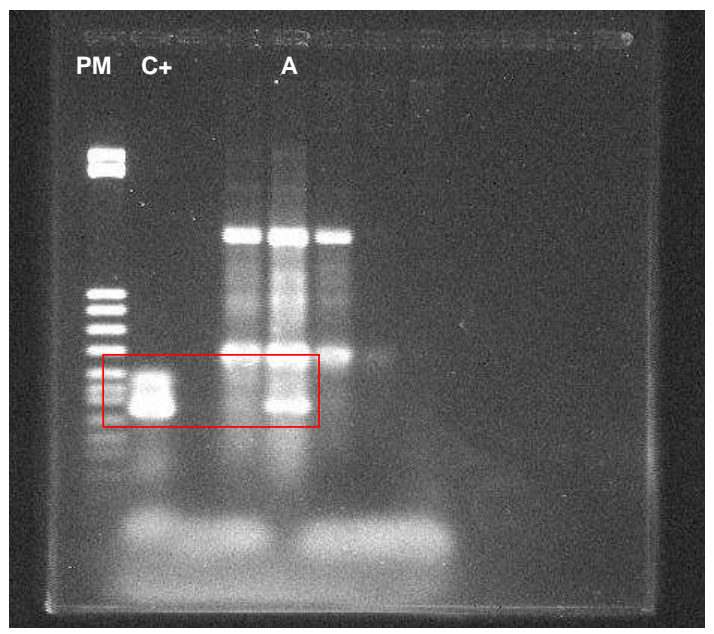

Figura 15 - PCR realizada para identificar fragmento genético do plasmídeo cp32-4, onde: $\mathrm{PM}=$ peso molecular (50bp); $\mathrm{C}_{+}=$controle positivo $B$. burgdorferi ; $A=$ amostra paciente SBY.

Porém, ao enviar o material para sequenciamento, observou-se existência de dois picos distintos de nucleotídeos. Este dado indica que no gel haveria duas bandas indistinguíveis entre si (muito próximas uma da outra), uma delas possivelmente relacionada com gene da borrelia e a outra homóloga ao cromossomo humano. Em resumo, primers derivados do complexo cp32 não permitiriam a identificação do agente etiológico da SBY, pois havia cruzamento com genes de cromossomos humanos.

O emprego dos primers para o gene flgE apresentou resultados negativos tanto para o grupo A como para o grupo controle.

\subsubsection{Grupo B}


Repetiu-se a PCR realizada com o gene flgE no grupo de 10 pacientes com histórico de EM e em atividade de doença, comparado com 49 controles de indivíduos normais. O teste também foi estendido de forma preliminar à 47 amostras de carrapatos oriundos de áreas de risco do Espírito Santo (sendo $17 R$. microplus e $30 R$. sanguineus), 27 bovinos e 26 equinos, animais estes oriundos da Universidade Federal Rural do Rio de Janeiro (UFRRJ).

A PCR foi positiva (Figura 16 e 17) em 06 pacientes SBY (60\%), 2 carrapatos (sendo $1 R$. sanguineus e $1 R$. microplus), 01 equino e 01 bovino. Estas amostras foram sequenciadas e apresentaram, uma similaridade de 99\% com Borrelia burgdorferi flagellar hook protein (flgE) gene (L43849).

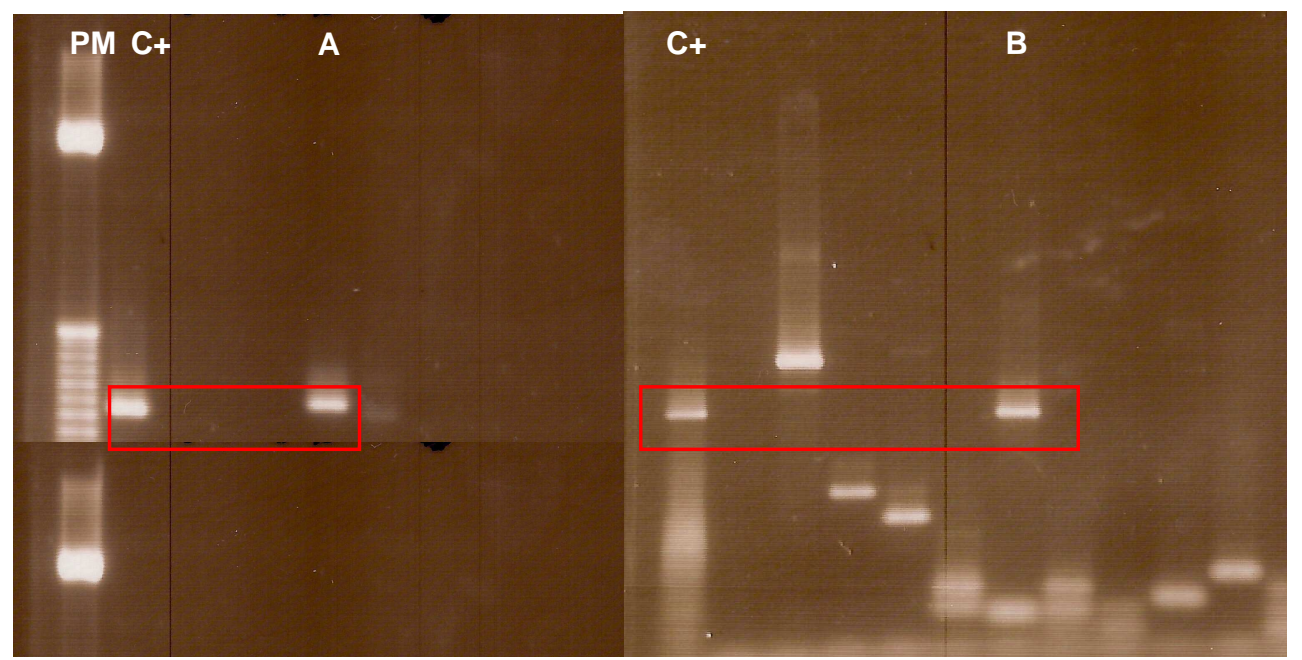

Figura 16 - PCR com flgE onde: $\mathrm{PM}=$ peso molecular (50bp); $\mathrm{C}+=$ = . garinii; $\mathrm{A}=$ amostra paciente SBY; $\mathrm{B}=$ amostra carrapato 


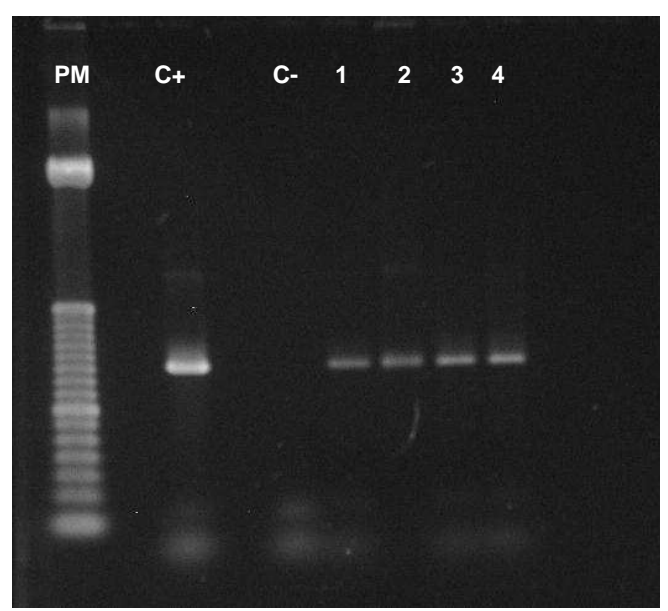

Figura 17 - PCR flgE onde: $\mathrm{PM}=$ peso molecular (50bp); $\mathrm{C}+=$ B. garinii; $\mathrm{C}-=$ controle normal; 1 ao $4=$ pacientes SBY

Salientamos que em todas as reações realizadas, o controle positivo utlizado foi a $B$. garinii, que quando sequenciado, apresentou uma homologia de $94 \%$ com Borrelia burgdorferi flagellar hook protein (flgE) gene (L43849) e de apenas $92 \%$ com a sequência das nossas amostras, eliminando assim, qualquer possibilidade de contaminação nas etapas dos procedimentos.

Todas as amostras do grupo controle apresentaram-se negativas para estes primers.

O fragmento sequenciado em nossas amostras, composto por 329pb, foi depositado no GenBank (acesso no HM 245929) e este possui 2 bases diferentes (em azul na Figura 18) do fragmento depositado (L43849) correspondente à Borrelia burgdorferi flagellar hook protein (flgE). 


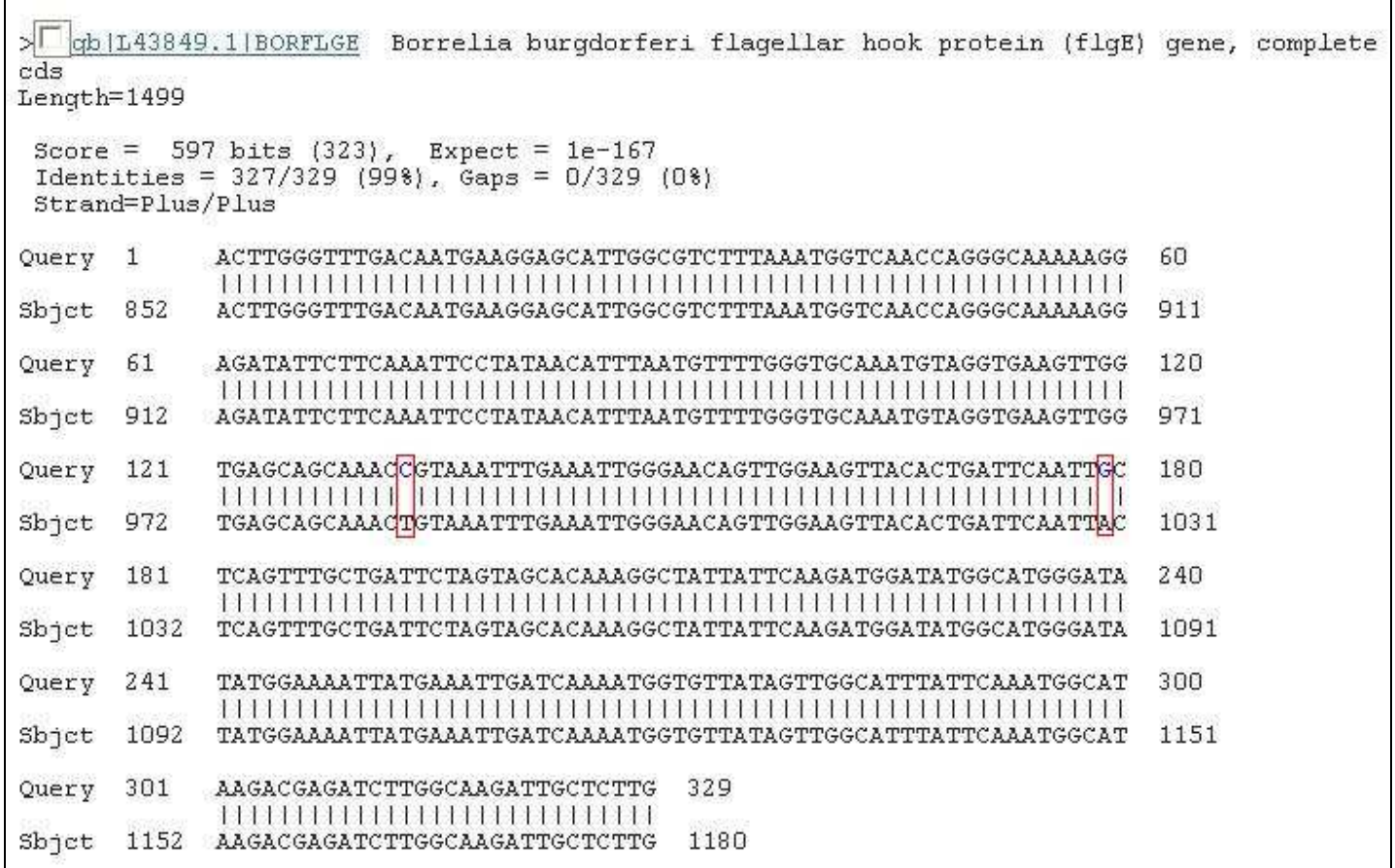

Figura 18 - Alinhamento das sequências das amostras positivas com o gene da Borrelia burgdorferi flagellar hook protein (flgE) (L43849) realizado no BLAST

Foi realizada também a PCR para Borrelia spp com os primers para os genes FlaB e 16S rRNA, as quais apresentaram resultados negativos para as 10 amostras de pacientes do grupo B. 
6. Discussão 
O principal objetivo do estudo foi alcançado, pois identificamos o agente etiológico da SBY, através do desenvolvimento de primers específicos para amplificação do gene do gancho flagelar da B. burgdorferi $(f l g E)$.

Através da análise do Western Blotting realizado com pacientes SBY, o qual indicava a presença de anticorpos contra proteínas flagelares da $B$. burgdorferi (banda de $41 \mathrm{Kda}$ ) na maioria dos pacientes, os pesquisadores do LIM-17 aprofundaram os estudos nos componentes flagelares.

O flagelo tem sua síntese regulada por uma cascata de eventos transcricionais, envolvendo a expressão ordenada de genes das classes 1, 2 e 3 (Aldridge e Hughes, 2002). A expressão dos genes de classe 1 dirige a transcrição dos genes da classe 2 , os quais codificam as proteínas estruturais envolvidas na síntese do corpo basal e do gancho (exemplos: flgM, $\sigma 28, f(g E)$, bem como proteínas reguladoras específicas. Estas proteínas reguladoras controlam a expressão dos genes da classe 3 , incluindo aqueles que codificam a flagelina e a quimiotaxia (FlaA e FlaB) (Sal et al., 2008). Assim, imaginamos que a Borrelia brasileira poderia ter deficiência nos genes reguladores da flagelina (FLaA e FLaB) (previamante demonstrado no LIM-17 do HCFMUSP), mas que teria conservado ativo o gene responsável pela síntese do gancho flagelar (flgE).

Os resultados preliminares com o flgE trouxeram grandes surpresas. Conseguimos identificar a presença do fragmento deste gene em 06 amostras de pacientes com SBY do grupo B. Acreditamos que a positividade esteve presente neste grupo pelo fato da doença estar em atividade no 
momento da coleta de sangue e, possivelmente, as borrelias estarem circulantes, diferentemente do grupo A, onde a maioria dos pacientes estava em estágio latente. Este dado é de grande relevância clínica, pois mostra que o primer flgE embora útil no descobrimento do agente etiológico da SBY, não seria apropriado no auxílio diagnóstico laboratorial da maioria dos casos da zoonose, que na grande maioria, são identificados na fase latente da enfermidade.

Além disso, a PCR para flgE apresentou-se positiva em 02 amostras de carrapatos, 01 de equino e 01 de bovino. Todas as amostras positivas apresentaram no sequenciamento uma homologia de 99\% com Borrelia burgdorferi flagellar hook protein (flgE) gene (L43849). Este dado leva-nos a supor que, podemos estar frente a uma nova espécie de Borrelia, muito próxima a Borrelia burgdorferi, já que a diferença entre a sequência brasileira e a da $B$. burgdorferi é de apenas 2 pares de bases. Esta diferença se repete em todas as nossas amostras, seja ela de humanos, carrapatos ou animais.

A descoberta dos primers flgE propiciou também o avanço no conhecimento da epidemiologia da SBY, pois conseguimos identificar de forma preliminar, o agente etiológico da SBY em carrapatos Rhipicephalus sanguineus e Rhipicephalus microplus, confirmando que os vetores no Brasil não pertencem aos carrapatos do complexo Ixodes ricinus.

Devido ao fato de alguns animais (1 equino e 1 bovino) provenientes da Universidade Federal Rural do Rio de Janeiro terem sido positivos para estes primers e apresentarem a mesma homologia de $99 \%$ com a $B$. 
burgdorferi, como os humanos e carrapatos, contribui de modo relevante na compreensão da epidemiologia da SBY, pois indica a possibilidade dos animais como cães, equinos e bovinos participarem como animais reservatórios no país.

Discutiremos a seguir, o porquê da SBY ser tão diferente da DL, quanto aos aspectos epidemiológicos,clínicos, laboratoriais e terapêuticos, uma vez que a $B$. burgdorferi é o mesmo agente de ambas as enfermidades, existindo inclusive uma homologia de $99 \%$ no gene flgE. Saliente-se que esta é a primeira descrição da $B$. burgdorferi no Hemisfério Sul, e que os pesquisadores ainda não admitiram a existência da clássica DL nesta área do planeta.

Quando o presente estudo foi iniciado, partimos do princípio de que a SBY seria uma enfermidade, causada por um conjunto de micro-organismos latentes, incluindo-se uma espiroqueta ainda indefinida, Mycoplasma spp e Chlamydia spp, como havia sido sugerido os achados preliminares da microscopia eletrônica realizados por Mantovani et al. (2007).

Mas, após a conclusão dos ensaios sorológicos para estes agentes, vimos que as frequências de sorologias positivas para Mycoplasma pneumoniae e para Chlamydia spp, foram semelhantes no grupo de pacientes SBY e controles normais.

A literatura aponta que a positividade na IFI para Chlamydia spp pode representar uma infecção aguda (IgM) ou exposição passada à Chlamydia (lgG) ou aquisição passiva de anticorpos por transfusão sanguínea, transplante de órgãos ou transferência placentária. Muitas 
infecções por Chlamydia são assintomáticas ou com o mínimo de sintomatologia (Swartz e Kraus, 1979). As infecções por C. pneumoniae e M. pneumoniae não são geralmente identificadas na população saudável, pois a etiologia das infecções respiratórias é investigada apenas em uma pequena parcela de pacientes, especialmente em casos prolongados, onde há falha com a terapia convencional ou quando a pneumonia requer hospitalização (Tuuminen et al., 2000). Estas informações podem explicar então a frequência semelhante das sorologias nos dois grupos (SBY e normais).

Os dados da sorologia para Chlamydia spp e Mycoplasma pneumoniae acrescidos dos resultados de Biologia Molecular (PCR), que foram negativos para estes micro-organismos, abriram possibilidades diferentes na interpretação dos resultados observados em nosso estudo.

Com base nas informações da literatura, sugeriu-se então que estas diferentes estruturas de morfologias semelhantes à Mycoplasma spp e Chlamydia spp, poderiam representar morfologias atípicas exibidas por espiroquetas, na tentativa de sobreviverem em meios inadequados de cultivo (Butler e Blakey, 1975; Murgia e Cinco, 2004). Nestas condições, as bactérias assumem diferentes morfologias como as bactérias na forma $L$, também conhecida como CWDB (Cell Wall Deficient Bacteria); corpos densos de dupla membrana; bacteroides sem flagelos ou esporos (blebs).

As bactérias na forma $L$ são desprovidas de parede celular e do ponto de vista morfológico, são idênticas aos Mycoplasma spp (Clasener, 1972; Onwuamaegbu et.al ,2005; Young, 2007); os corpos densos de dupla 
membrana são semelhantes às Chlamydia spp, e os bacteroides lembram espiroquetídeos. Dentre as condições desfavoráveis de cultivo, que induzem o surgimento destas estruturas, citam-se as mudanças de nutriente, $\mathrm{pH}$ e presença de antibióticos (Butler e Blakey, 1975; Murgia e Cinco, 2004).

Estas bactérias de morfologia atípica, geralmente não são patogênicas (Domingue e Woody, 1997; Brorson e Brorson, 1998) e costumam reverter à morfologia original, quando as condições do meio ambiente voltam a ser favoráveis (Charache,1970).

Fato intrigante foi o encontro pela análise em microscopia óptica (MO) de campo escuro, no sangue periférico dos indivíduos normais (grupo controle), a presença de micro-organismos (espiroquetídeos) em cerca de $20 \%$ das amostras. Estas estruturas quando analisadas à ME, exibem formações que lembram Mycoplasma spp, e na verdade, representam bactérias desprovidas de parede celular (CWDB) (Yoshinari et al., 2009).

A Literatura Médica registra que qualquer bactéria em condições inadequadas de crescimento, pode sofrer transformação para a forma $L$, contudo, a visualização destes micro-organismos na apresentação CWDB não havia sido registrada ainda em indivíduos normais. Yoshinari et al. (2009), descreve pela primeira vez, através de microscopia de campo escuro, estruturas de comportamento latente no sangue periférico de animais de laboratório e de funcionários do Centro de Bioterismo da FMUSP. Estas estruturas que lembram espiroquetas, quando analisadas à microscopia eletrônica, revelaram bactérias com características de Mycoplasma spp, ou seja, CWDB. Desde que estas formas $L$ de bactérias 
não são patogênicas, sugeriu-se que os animais e funcionários do Centro de Bioterismo, estavam contaminados por micro-organismos latentes saprófitas. Verificou-se também, que a frequência de contaminação por espiroquetídeos no sangue periférico estava dependente das condições de higiene locais.

Assim, quando visualizamos grande quantidade de espiroquetídeos no sangue periférico de pacientes com SBY (frequência de cerca de $90 \%$ ), assumimos que, parte dos micro-organismos, são CWDB oriundos de bactérias da flora saprofítica normal, possivelmente derivados do trato digestivo e/ou vias respiratórias. Contudo, acreditamos que parte dos espiroquetídeos visualizados nos pacientes com SBY seja de fato $B$. burgdorferi na apresentação atípica. É possível também que, a disfunção imunológica observada na SBY contribua para o surgimento dos espiroquetídeos.

Outras formas de bactérias em apresentação vegetativa são descritas na Literatura Médica, quando espiroquetas são cultivadas em condições adversas de $\mathrm{pH}$, temperatura ou na presença de antibióticos (Kersten et al., 1995; Murgia e Cinco, 2004; Austrauskiene e Bernotiene, 2007). As bactérias desenvolvem alterações estruturais que variam de minúsculos pontos ou esporos, conhecidos como blebs, até formações que lembram bactérias alongadas (espiroquetas desprovidas de flagelos?) ou estruturas semelhantes a corpos densos de dupla membrana semelhantes à Chlamydia spp (Kersten et al., 1995). É interessante comentar que, morfologias atípicas de borrelias, têm sido descritas no parênquima cerebral de doentes com neuroborreliose e em tonsilas (Miklossy et al., 2008; Duray et al., 2005). 
As alterações morfológicas encontradas na $B$. burgdorferi podem estar associadas com a perda ou inativação de determinados genes (mutações), que regulam a síntese de flagelos ou lipoproteínas de superfície (Osp). Embora as mutações nas borrelias sejam raras, existem inúmeras descrições na Literatura (Sadziene et al., 1993; Yang et al., 2000; Malawista et al., 2000; Motaleb et al., 2004; Derdáková e Lencáková, 2005; Fingerle et al., 2007).

Por outro lado, modificações genéticas e da expressão proteica transitórias, ocorrem espontaneamente com a $B$. burgdorferi, nas fases que infectam diferentes hospedeiros mamíferos ou carrapatos. Esta variabilidade na expressão gênica e proteica exibidas pelas borrelias quando da sua passagem pelos diferentes hospedeiros, são de cunho adaptativo, de modo a permitir a sua sobrevivência e disseminação nos diferentes organismos infectados (Gilmore et al., 2001; Tilly et al., 2006). Por exemplo, a $B$. burgdorferi quando infecta hospedeiro mamífero é capaz de sintetizar um fator proteico, que neutraliza a ação lítica bactericida do sistema complemento (Babb et al., 2006).

Espiroquetas do complexo B. burgdorferi sensu lato mantêm estreita relação de dependência com carrapatos do complexo Ixodes ricinus, tanto que todas as espécies de vetores transmissores da DL nos EUA e Eurásia pertencem ao gênero Ixodes (Krupka et al., 2007; Hovius et al., 2007). Como comentado anteriormente, existem inúmeras interações em níveis moleculares entre a $B$. burgdorferi e os hospedeiros vertebrados e invertebrados, especialmente quanto à expressão ou supressão das 
lipoproteínas da membrana externa (Osp A, B, C, D, E, F) (Gilmore et al., 2001; Tilly et al., 2006; Barbour et al., 2006; Krupka et al., 2007; Palmer et al., 2009).

É possível supor então que, a falta de vetores do gênero Ixodes, habitualmente presentes no Hemisfério Norte, tenha originado borrelias de morfologia atípica, adaptadas à sobreviver em condições geográficas e de biodiversidade próprias do território brasileiro.

Embora de maneira preliminar, demonstramos que no Brasil, temos carrapatos dos gêneros Rhipicephalus infectados com B. burgdorferi, confirmados através da PCR. Interessante que, nos EUA é descrita a enfermidade de Masters ou STARI, causada por B. lonestari, incultivável em meio BSK, e transmitida pelo Amblyomma americanum. A diferença é que a zoonose americana causa apenas lesão de pele (EM), enquanto a SBY origina lesões cutâneas e complicações sistêmicas.

Mutações em determinados genes implicam na ausência ou na síntese incompleta de determinadas proteínas como as de flagelo e as de membrana externa (outer superface proteins - Osp) (Sal et al., 2008). O fato dos pacientes com SBY terem sido negativos nos ensaios de PCR para gene flagelina da Borrelia spp (FlaB), pode justificar porque a B. burgdorferi encontrada no país encontra-se na forma bacteroide sem flagelos, visto que espiroquetas desprovidas deste gene perdem a morfologia helicoidal, típica das borrelias (Motaleb et al., 2000).

A parede bacteriana, assim como a camada externa da B. burgdorferi, constituída de peptideoglicanos contribuem na contenção do citoplasma e 
são fatores importantes que determinam a morfologia bacteriana (Denome et al., 1999). Portanto, o insucesso em corar espiroquetídeos vistos nas nossas culturas e no sangue periférico, estaria ligado também à este fator, pois os métodos de Gram, Panótico e Rosenfeld são utilizados para a coloração de parede (constituída de peptideoglicanos) e, na ausência desta, os resultados acabam sendo negativos. Este achado reforça a hipótese de que, os espiroquetídeos visualizados à microscopia de campo escuro nos indivíduos normais e com SBY, sejam estruturas desprovidas de parede celular, a exemplo dos Mycoplasma spp. Justifica também, porque crescem em meio SP-4, ideal para desenvolvimento de Spiroplasma spp, que pertencem ao grupo dos Mollicutes, ou seja, micro-organismos desprovidos de parede e com membrana celular rica em colesterol. Estudos anteriores realizados no LIM-17 do HCFMUSP por Costa (1998) e Barros (2000) já haviam mostrado que primer derivado do gene codificador da proteína OspA, fora ineficaz para identificar B. burgdorferi no Brasil. Este dado reforça a hipótese de que a $B$. burgdorferi presente no país, seria deficiente em constituintes da membrana externa da espiroqueta.

A hipótese de que a SBY seja causada pela B. burgdorferi de morfologia atípica, sem flagelos e desprovida de inúmeros constituintes da membrana externa, possivelmente consequente à deleção ou repressão gênica, também explica a baixa sensibilidade dos testes sorológicos para a B. burgdorferi de origem americana. Como mostramos no presente trabalho, verificamos que apenas $65 \%$ dos doentes do grupo $A$ foram positivos, contra $16 \%$ de positividade do grupo controle. Estes resultados mostram que, 
embora úteis, do ponto de vista prático, os testes de ELISA e WB devem ser interpretados com muita cautela, pela ocorrência de falsos negativos e positivos.

No intuito de estudar o comportamento das borrelias quando semeadas em diferentes meios, optamos por cultivar B. burgdorferi G39/40 de origem americana, em meio BSK e em meio SP4, considerando-se o primeiro como adequado e o segundo impróprio ao desenvolvimento de borrelias. As bactérias cultivadas em meio BSK cresceram bastante e foram coradas adequadamente com Panótico e Acridine orange. Já a cultura de B. burgdorferi G39/40 semeada em meio SP-4, não atingiu o nível de crescimento esperado, e a morfologia das bactérias apresentou-se alterada, com surgimento de formações atípicas de diferentes formas e tamanhos. Este experimento reproduz in vitro, a grande capacidade das borrelias se modificarem morfologicamente e de se adaptarem aos meios inadequados de cultivo, transformando-se em formas vegetativas, como as formas císticas.

Consideramos que, a $B$. burgdorferi encontrada no Brasil, seja o resultado de mutações que originaram bactérias morfologicamente atípicas, com expressões gênicas e proteicas diferentes da encontrada no Hemisfério Norte. Estas modificações foram necessárias, objetivando a adaptação das espiroquetas às condições de sobrevida em hospedeiros vertebrados e invertebrados encontrados no país. Neste sentido, Derdáková e Lencáková (2005) comentam que variações geográficas e ecológicas, podem determinar o surgimento de diferentes genoespécies de B. burgdorferi, 
consequente à ocorrência de grande variabilidade de hospedeiros vertebrados e carrapatos, determinando a múltipla diversidade quanto à patogenicidade, manifestação clínica, procedimentos diagnósticos laboratoriais e mecanismos de transmissão.

A antibioticoterapia com penicilina, doxiciclina e ceftriaxona é um procedimento considerado adequado ao tratamento da borreliose de Lyme. Apesar da sobrevivência de borrelias após antibioticoterapia ser negada por maioria de pesquisadores, em alguns pacientes, tem sido mostrado que a borrelia pode sobreviver nos tecidos, fazendo com que estes pacientes tenham um quadro de recidiva da doença. Um trabalho realizado por Kersten et al.(1995), mostrou os diferentes modos de degeneração da B. burgdorferi, que se segue após a inoculação de vários antibióticos in vitro, obtendo a formação de grânulos e estruturas císticas durante a exposição aos medicamentos (Figura 19).

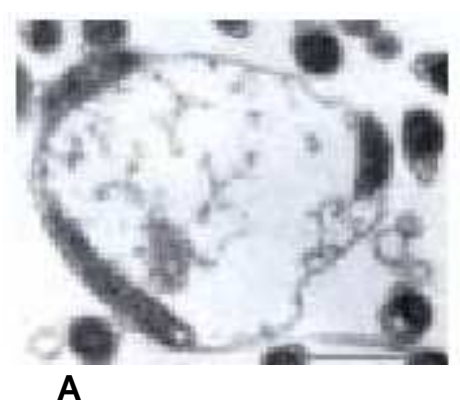

A

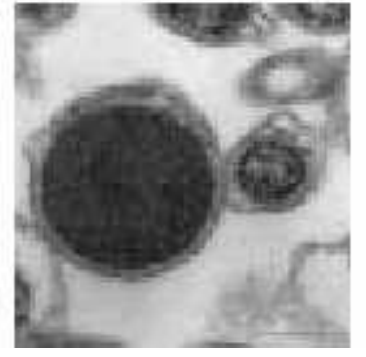

B

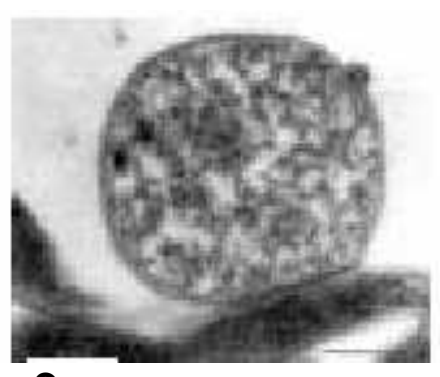

C

Figura 19 - Formação de estruturas císticas em cultura de B. burgdorferi após exposição aos antibióticos, onde: $A$ - Formação de vesículas (forma $L$ ) após 24 horas de exposição ao ceftriaxona; B-Desenvolvimento de corpo esférico após 96 horas de exposição à doxiciclina (cisto); C- Vesícula (forma L) aderindo em outra superfície da espiroqueta após 24 horas de exposição à penicilina (Kersten et al., 1995). 
As fotos da Figura 19 quando comparadas com os nossos resultados à ME (Figura 20), são praticamente idênticas do ponto de vista morfológico, mostrando que as diferentes estruturas encontradas no sangue periférico de pacientes com SBY, representariam estágios morfológicos distintos da Borrelia spp. O fato da B. burgdorferi presente no Brasil jamais ter sido cultivada ou isolada na sua forma espiralada e nem ser identificada através de técnicas de biologia molecular preconizadas no Hemisfério Norte, sugere que o micro-organismo responsável pela SBY, seja uma bactéria mutante estável, que incorporou em definitivo as modificações genéticas, bioquímicas e morfológicas, adquiridas para a sua sobrevivência no país.
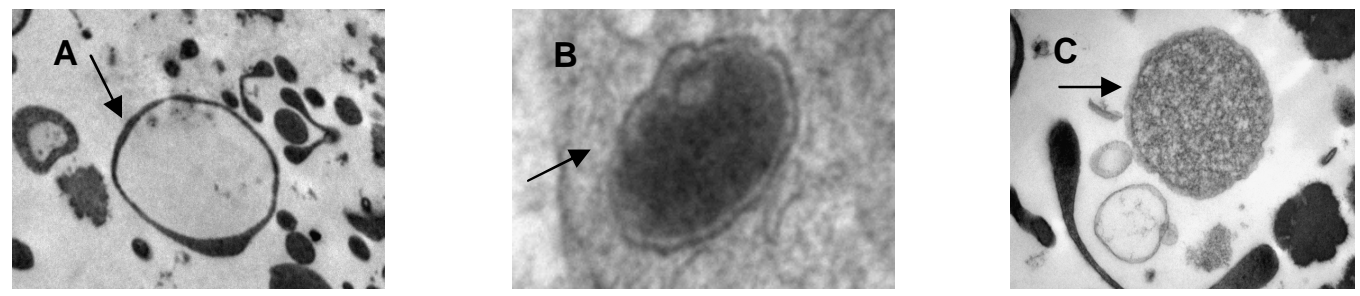

Figura 20 - Amostras visualizadas à ME onde: A- Sangue de paciente com SBY semeado em SP-4, na qual pode-se visualizar a formação de vesícula (cisto); B-Sangue periférico de paciente com SBY, onde visualiza-se a formação de um corpo esférico denso semelhante à Chlamydia spp; CSangue de paciente com SBY semeado em SP-4, onde pode-se observar uma formação semelhante à Mycoplasma spp acima de uma espiroqueta.

Preac-Mursic et al. (1986) observaram em culturas de B. burgdorferi contendo antibióticos, formação de "blebs" (expansões circulares originadas de espiroquetas), estruturas esféricas e grânulos (Figura 21). 


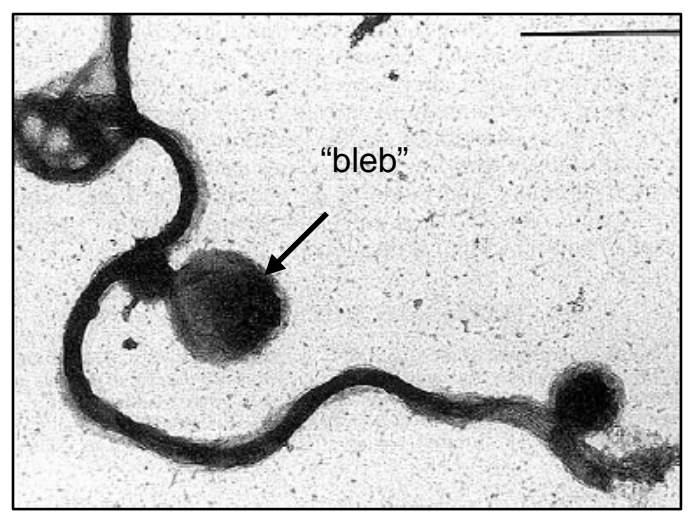

Figura 21 - Formação de "blebs" e grânulos em cultura de B. burgdorferi após 24 horas de incubação com ceftriaxona (Preac-Mursic et al., 1986).

A imagem acima pode ser comparada com a nossa cultura de $B$. burgdorferi semeada em meio SP-4, não apropriado para o crescimento bacteriano, que mostra a formação de corpos arredondados presos às espiroquetas (Figura 22). Interessante que, estas formas císticas ("blebs") representam uma forma de defesa do micro-organismo, pois em condições adequadas de cultivo, cada um destes cistos pode reproduzir uma nova espiroqueta.

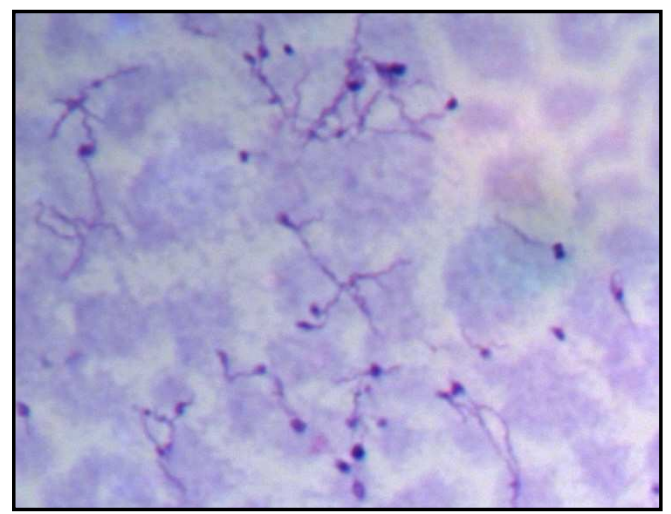

Figura 22 - Cultura de B. burgdorferi semeada em meio SP-4, corada pelo Panótico (1000X). 
As formas atípicas vegetativas de borrelias e treponemas podem estar associadas com infecções de caráter crônico e recorrente, pelo fato destas estruturas serem resistentes aos antibióticos e serem capazes de burlar o sistema imunológicos dos hospedeiros, pois tem sobrevida intracelular (Clasener, 1972). Balfour em 1911 relatava a presença de formas císticas intracelulares em punções de fígado, baço e pulmão de aves com espiroquetose, enquanto outros estudos mais recentes mostram que as borrelias são micro-organismos com capacidade de infectar diferentes células, como as endoteliais (Figura 23) (Comstock et al., 1989; Thomas et al., 1989; Ma et al., 1991), mononucleares e fibroblastos (Georgilis et al., 1991).

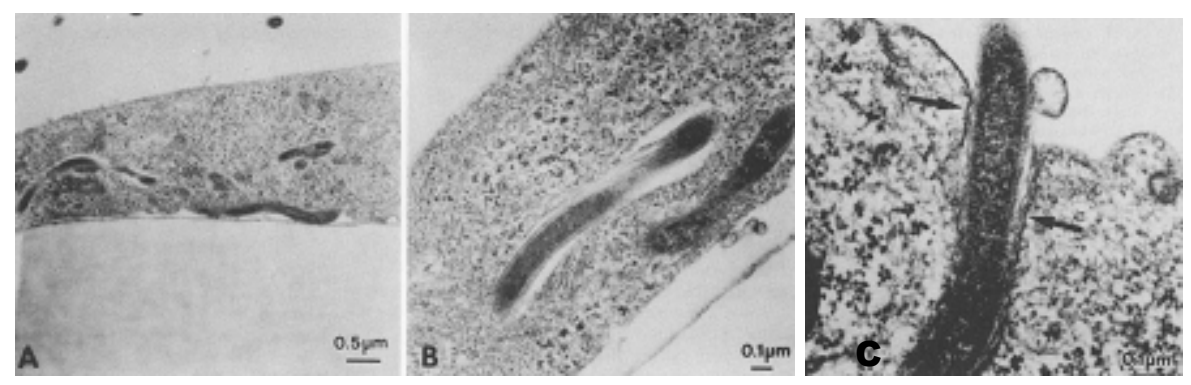

Figura 23 - Microscopia eletrônica mostrando Borrelia burgdorferi penetrando em células endoteliais (HUVEC), onde: A e B - Células HUVEC em monocamadas com borrelias intracelulares; $C$-Borrelia entrando na célula. As setas indicam a membrana da HUVEC (Comstock et al., 1989).

Ao semearmos a B.burgdorferi G39/40 de origem americana em células endoteliais, confirmamos os resultados acima mostrados. Outro fato notável foi a mudança da morfologia da borrelia inoculada, que perdeu o seu aspecto helicoidal (Figura 24). 


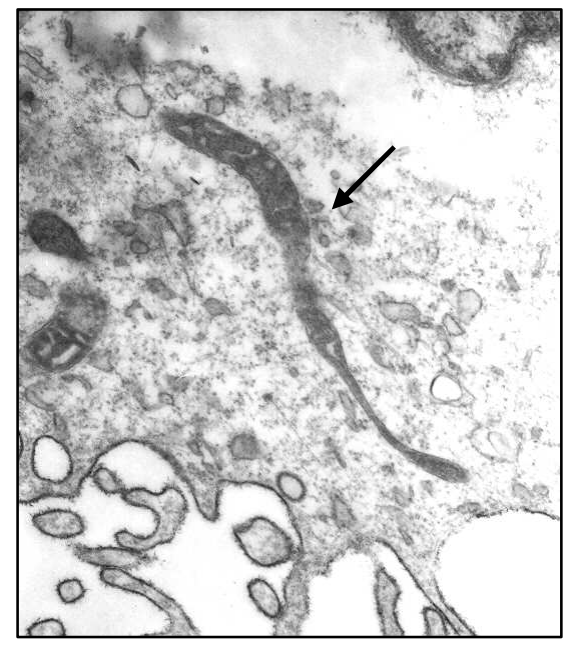

Figura 24 - Cultura de Borrelia burgdorferi (cultivada em BSK) e inoculada posteriormente em células endoteliais. Visualiza-se espiroqueta de morfologia atípica no interior da célula endotelial (Enviada à ME após 3 dias de inoculação das borrélias na cultura de células endoteliais. Aumento de 7200X.)

Muito interessante foi o estudo realizado por Duray et al. (2005), que ao inocular B. burgdorferi em cultura de tecido tonsilar, observou que as bactérias invadem e colonizam as células, originando espiroquetas de morfologia modificada, incluindo presença de estruturas císticas (Figura 25). 


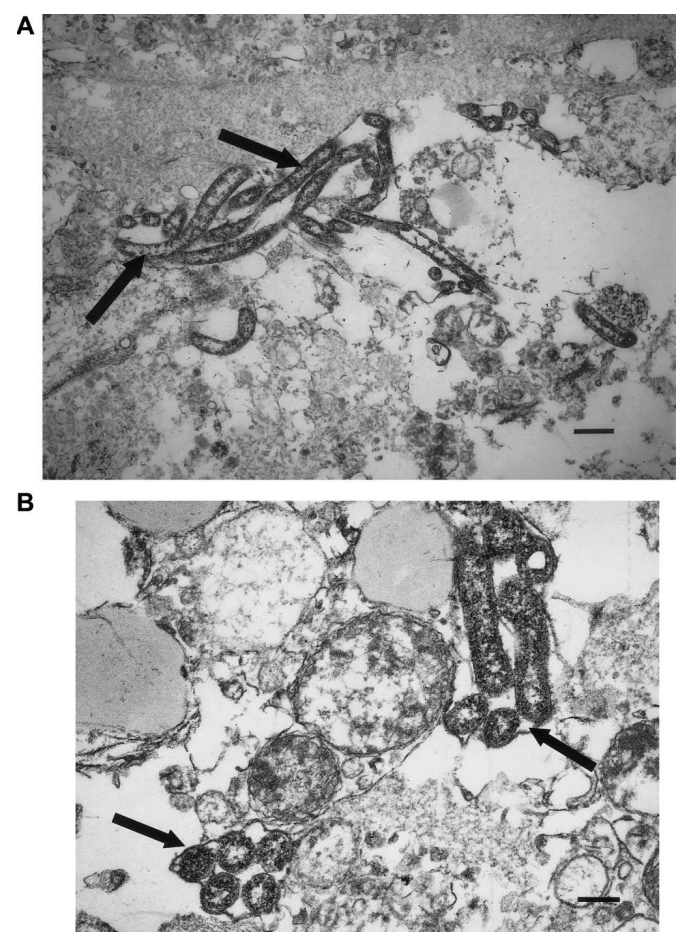

Figura 25 - Microscopia Eletrônica de B. burgdorferi inoculada em tecido tonsilar. Setas indicam numerosas espiroquetas de morfologia anômala $(A)$ e formas císticas de $B$. burgdorferi presentes no interior de células (Duray et al., 2005).

Resolvemos então cultivar células endoteliais, para torná-las substrato de crescimento dos espiroquetídeos, na tentativa de simular tecido humano vivo, visto que, os espiroquetídeos identificados nos pacientes com SBY, não se desenvolviam em meio BSK ou cresciam por pequeno período de tempo no meio SP-4.

Conseguimos demonstrar que, a inoculação direta de espiroquetídeos visualizados nos sangue periférico de pacientes com SBY, assim como os previamente semeados em meio SP-4, conseguiram invadir células endoteliais. Curiosamente, assumiram morfologias de micro-organismos que 
lembravam espiroquetas, Mycoplasma spp e Chlamydia spp, na verdade, morfologias atípicas da Borrelia spp, conforme comentado anteriormente.

O fato do sequenciamento mostrar que a Borrelia causadora da SBY pertence ao complexo Borrelia burgdorferi sensu lato, aliado ao fato de jamais termos conseguido o isolamento das bactérias em meio BSK, sugerem fortemente a hipótese de que no Brasil, a enfermidade é causada por espiroquetas na apresentação latente. Além da visualização de morfologias na apresentação vegetativas à $\mathrm{ME}$, os dados clínicos, laboratoriais e terapêuticos corroboram com esta descoberta inusitada.

Definimos hoje a Síndrome de Baggio-Yoshinari como zoonose emergente, até o momento, encontrada apenas no Brasil, causada pela Borrelia burgdorferi na apresentação morfológica atípica, transmitida por carrapatos não pertencentes ao complexo Ixodes ricinus, responsável pelo desenvolvimento de manifestações clínicas semelhantes à Doença de Lyme, exceto pela grande frequência de sintomas recorrentes e complicações imuno-alérgicas. Este conceito implica em afirmar que, uma mesma bactéria, quando submetida às diferentes condições de sobrevivência, como, por exemplo, a biodiversidade da fauna ou variações geográficas, pode desencadear enfermidades distintas.

A presente pesquisa tem o mérito de elucidar o agente etiológico da SBY, porém aborda temas altamente polêmicos, jamais comentados anteriormente. Acreditamos que a SBY seja um modelo de enfermidade extremamente importante no conhecimento da relação hospedeiro-infecção e sua conexão com o desencadeamento de mecanismos autoimunes. 
7. Conclusões 
1- A Borrelia burgdorferi sensu lato é o agente etiológico da Síndrome Baggio-Yoshinari.

2- A Borrelia burgdorferi sensu lato foi identificada em carrapatos do gênero Rhipicephalus e nos animais domésticos (bovinos e eqüinos).

3- Foi descartada a hipótese da participação dos micro-organismos latentes Mycoplasma spp e Chlamydia spp na etiologia da SBY.

4- Na SBY os achados epidemiológicos, clínicos, laboratoriais e de terapêutica são distintos da DL, permitindo afirmar que, no Brasil existe uma nova zoonose emergente transmitida por carrapatos.

5- Sugere-se que a SBY seja causada por espiroquetas na morfologia atípica, de vida intracelular, justificando a longa persistência do microorganismo no homem e explicando os episódios de recorrência clínica.

6- O emprego dos primers para identificação do fragmento do gene flgE, responsável pela síntese do gancho flagelar, permitiu a identificação do agente etiológico da SBY, mas não é procedimento laboratorial útil na rotina diagnóstica. 
8. Anexos 


\subsection{Aprovação da CAPPesq}

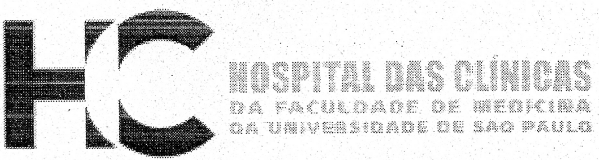

Ao

Departamento de Clinica Médica

A Comissão de Ética para Análise de Projetos de Pesquisa - CAPPesq da Diretoria Clínica do Hospital das Clínicas e da Faculdade de Medicina da Universidade de São Paulo, em sessão de 24.09.08, tomou conhecimento que o Protocolo de Pesquisa $n^{\circ}$ 0895/05 intitulado "Estudo dos agentes Etiológico da Síndrome Infecto-Reacional Lyme-Símile", contempla o sub-projeto intitulado "Pesquisa de Chlamydias Mycoplasma e Borrelias no Sangue periférico dos pacientes com Síndrome Infecto-Reacional Lyme-Símile ", que será tese doutorado da aluna Elenice Mantovani, bem como tomou conhecimento do relatório parcial do estudo.

Pesquisador Responsável: Prof. Dr. Natalino Hajime Yoshinari

São Paulo, 30 de junho de 2008.

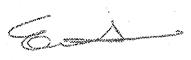

PROF. DR. EDUARDO MASSAD

Presidente da Comissāo de Étic a para Análise

de Projetos de Pesquisa

Comissão de Ética para Análise de Projetos.de Pesquisa do HCFMUSP e da FMUS

Diretoria Clínica do Hospital das Clínicas da Faculdade de Medicina da Universidade de São Paulo

Rua Ovílio Pires de Campos. 225, $5^{\circ}$ andar - CEP 05430010 - São Paulo - SP

Fone: 011 - $30696442 \mathrm{fax}: 011$ - 30696492 - e-mail : cappesq@hcnet.usp.br / secretariacappesq2@hcnet.usp.br 


\section{Referências bibliográficas}


Abel IS, Marzagão G, Yoshinari NH, Schumaker TT. Borrelia-like spirochetes recovered from ticks and small mammals collected in the Atlantic Forest Reserve, Cotia county, State of São Paulo, Brazil. Mem Inst Oswaldo Cruz. 2000, 95(5):621-4.

Aldridge $\mathrm{P}$, Hughes KT. Regulation of flagellar assembly. Curr. Opin. Microbiol. 2002, 5:160-5.

Altschul SF, Gish W, Miller W, Myers EW, Lipman DJ. Basic local alignment search tool. J Mol Biol. 1990;215:403-10.

Asch ES, Bujak DI, Weiss M, Peterson MG, Weinstein A. Lyme disease: an infectious and post infection syndrome. J Rheumatol. 1994; 21:454-461.

Astrauskiene D, Bernotiene E. New insights into bacterial persistence in reactive arthritis. Clin Exp Rheumatol. 2007 May-Jun;25(3):470-9.

Babb K, Bykowski T, Riley SP, Miller MC, Demoll E, Stevenson B. Borrelia burgdorferi EbfC, a novel, chromosomally encoded protein, binds specific DNA sequences adjacent to erp loci on the spirochete's resident cp32 prophages. J Bacteriol. 2006 Jun;188(12):4331-9.

Balfour A. The infective granule in certain protozoal infections, as illustrated by the spirochaetosis of Sudanese fowls. BMJ 1911;1:752. 
Barbour AG, Hayes SF. Biology of Borrelia species. Microbiol. 1986, Rev.50:381-400.

Barbour AG, Dai Q, Restrepo BI, Stoenner HG, Frank SA. Pathogen escape from host immunity by a genome program for antigenic variation. Proc Natl Acad Sci U S A. 2006 Nov 28;103(48):18290-5.

Barros PJL. Caracterização clínica e laboratorial da doença de Lyme no Brasil, através de métodos imunológicos e reação e, cadeia de polimerase. [tese de doutorado], São Paulo: Faculdade de Medicina da Universidade de São Paulo, FMUSP; 2000.

Barros-Battesti DM, Yoshinari NH, Bonoldi VLN, Gomes AC. Parasitism by Ixodes didelphidis and I. Ioricatus (Acari: Ixodidae) on Small Wild Mammals from an Atlantic Forest in the State of Sao Paulo, Brazil. J Med Entomol 2000; 37 (6): 820-827.

Brorson $\mathrm{O}$, Brorson $\mathrm{SH}$. A rapid method for generating cystic forms of Borrelia burgdorferi, and their reversal to mobile spirochetes. APMIS. 1998 Dec;106(12):1131-41.

Burgdorfer W, Barbour AG, Hayes SF. Lyme disease: a tick borne spirochetosis? 1982; Science; 216:1317-1319. 
Butler HM, Blakey JL. A review of bacteria in L-phase and their possible clinical significance. Med J Aust. 1975 Sep 20;2(12):463-7.

Charache P. Cell wall-defective bacterial variants in human disease. Ann $N Y$ Acad Sci 1970; 174: $903-911$.

Clarissou J, Song A, Bernede C, Guillemot D, Dinh A, Ader F, Perronne C, Salomon J. Efficacy of a long-term antibiotic treatment in patients with a chronic Tick Associated Poly-organic Syndrome (TAPOS). Med Mal Infect. 2009 Feb;39(2):108-15.

Clasener H. Pathogenicity of the L-phase of bacteria. Annu Rev Microbiol. 1972;26:55-84.

Comstock LE, Thomas DD. Penetration of endothelial cell monolayers by Borrelia burgdorferi. Infect Immun. 1989 May;57(5):1626-8.

Cordova CMM, Cunha RAF. Detecção de Mycoplasma genitalium, M. fermentans e $M$. penetrans em pacientes com sintomas de uretrite e em indivíduos infectados pelo HIV-1 no Brasil. J. Bras. Patol. Med. Lab., 2002 v.38 n.2 .

Costa IP. Pesquisa de anticorpos anti-Borrelia e do agente etiológico em soro e liquor de pacientes com manifestações clínicas compatíveis com a 
Doença de Lyme, no Estado de Mato Grosso do Sul [tese de doutorado], São Paulo; Faculdade de Medicina da Universidade de São Paulo, FMUSP; 1998.

Costa IP, Bonoldi VLN, Yoshinari NH. Perfil clínico e laboratorial da Doença de Lyme-símile no Estado de Mato Grosso do Sul: análise de 16 pacientes. Rev Bras Reumatol 2001;41:142-150.

Costa IP, Bonoldi VLN, Yoshinari NH. Search for Borrelia sp in ticks from potential reservoir in an urban forest in the State of Mato Grosso do Sul, Brazil: a short report. Mem Inst Oswaldo Cruz, 2002; 97(5): 631-35.

Derdáková $M$, Lencáková $D$. Association of genetic variability within the Borrelia burgdorferi sensu lato with the ecology, epidemiology of Lyme borreliosis in Europe. Ann Agric Environ Med. 2005;12(2):165-72.

Denome SA, Elf PK, Henderson TA, Nelson DE, Young KD. Escherichia coli mutants lacking all possible combinations of eight penicillin binding proteins: viability, characteristics, and implications for peptidoglycan synthesis. J Bacteriol, 1999;181(13):3981-93.

Domingue GJ Sr, Woody HB. Bacterial persistence and expression of disease. Clin Microbiol Rev. 1997 Apr;10(2):320-44. 
Dressler F, Whalen JA, Reinhardt BN, Steere AC. Western blotting in the serodiagnosis of Lyme disease. J Infect Dis. 1993 Feb;167(2):392-400.

Duray PH, Yin SR, Ito Y, Bezrukov L, Cox C, Cho MS, Fitzgerald W, Dorward D, Zimmerberg J, Margolis L. Invasion of human tissue ex vivo by Borrelia burgdorferi. J Infect Dis. 2005 May 15;191(10):1747-54.

Feder HM Jr, Johnson BJ, O'Connell S, Shapiro ED, Steere AC, Wormser GP; et al. A critical appraisal of "chronic Lyme disease". N Engl J Med. 2007 Oct 4;357(14):1422-30.

Fingerle V, Goettner G, Gern L, Wilske B, Schulte-Spechtel U. Complementation of a Borrelia afzelii OspC mutant highlights the crucial role of OspC for dissemination of Borrelia afzelii in Ixodes ricinus. Int $\mathrm{J}$ Med Microbiol.. 2007;297(2):97-107.

Fonseca AH, Salles RS, Salles SAN, Madureira RC, Yoshinari $\mathrm{NH}$. Borreliose de Lyme símile: uma doença emergente e relevante para a Dermatologia no Brasil. An Bras Dermatol. 2005;80:171-8.

Fritz BA, Thomas CB, Van Ess P, Yuill TM. Comparison of a modified Edward-type medium and a modified SP4-type medium for primary isolation of Mycoplasma gallisepticum (MG) from chickens vaccinated with the F strain of MG. Avian Dis. 1991;35(3):591-8. 
Gauditano G, Bonoldi VLN, Costa IP, Battesti DMB, Barros PJL, Fonseca $\mathrm{AH}$, et al. Síndrome de Lyme-símile ou complexo infecto-reacional do carrapato - Síndrome de Baggio-Yoshinari. Revista Paulista de Reumatologia, 2005; 4: 16-17.

Gauditano G, Bonoldi VLN, Hiratsuka RC, Kiss MH, Yoshinari NH. Aspectos imunológicos comuns entre a Doença de Lyme e a Febre Reumática. Rev Bras Reumatol. 2000; 40:1-7.

Ge Y, Old IG, Saint Girons I, Charon NW. Molecular characterization of a large Borrelia burgdorferi motility operon which is initiated by a consensus б70 promoter. J Bacteriol. 1997, 179:2289-99.

Georgilis K, Steere AC, Klempner MS. Infectivity of Borrelia burgdorferi correlates with resistance to elimination by phagocytic cells. J Infect Dis. 1991 Jan;163(1):150-5.

Gilmore RD Jr, Mbow ML, Stevenson B. Analysis of Borrelia burgdorferigene expression during life cycle phases of the tick vector Ixodes scapularis. Microbes Infect, $2001 ; 3(10): 799-808$.

Grodzicki RL, Steere AC. Comparison of immunoblotting and indirect enzyme-linked immunosorbent assay using different antigens preparations for diagnosis of early Lyme disease. J. Infect. Dis. 157: 790-97, 1988. 
Guglielmone AA, Beati L, Barros-Battesti DM, Labruna MB, Nava S, Venzal JM, Mangold AJ, Szabó MP, Martins JR, González-Acuña D, Estrada-Peña A. Ticks (Ixodidae) on humans in South America. Exp Appl Acarol. 2006;40(2):83-100.

Hamer SA, Tsao J, Walker ED, Hickling GJ. Invasion of the Lyme Disease Vector Ixodes scapularis: Implications for Borrelia burgdorferi Endemicity. Ecohealth. 2010 Mar 13. [Epub ahead of print]

Herxheimer K. Zur Kenntnis der Spirochaeta Pallida. München med Wochschur. 1905; 53: 310-312.

Hovius JW, van Dam AP, Fikrig E. Tick-host-pathogen interactions in Lyme borreliosis. Trends Parasitol. 2007;23(9):434-8.

Iyer R, Kalu O, Purser J, Norris S, Stevenson B, Schwartz I. Linear and circular plasmid content in Borrelia burgdorferi clinical isolates. Infect Immun. 2003;71(7):3699-706.

Kersten A, Poitschek C, Rauch S, Aberer E. Effects of penicillin, ceftriaxone, and doxycycline on morphology of Borrelia burgdorferi. Antimicrob Agents Chemother. 1995;39(5):1127-33. 
Krupka M, Raska M, Belakova J, Horynova M, Novotny R, Weigl E. Biological aspects of Lyme disease spirochetes: unique bacteria of the Borrelia burgdorferi species group. Biomed Pap Med Fac Univ Palacky Olomouc Czech Repub. 2007 Dec;151(2):175-86.

Lennoff C. Spirochaets in aetiologically obscure diseases. 1949; Acta Derm. Venereol. 28:295-324.

Lipschultz B. Über eine seltene erythema chronicum migrans. Arch. Derm. Syph. 1913; 111:349

Logigian EL, Kaplan RF, Steere AC. Chronic neurologic manifestations of Lyme disease. N Engl J Med 1990;323:1438-44.

LoGiudice K, Ostfeld RS, Schmidt KA, Keesing F.The ecology of infectious disease: effects of host diversity and community composition on Lyme disease risk. Proc Natl Acad Sci USA, 2003; 100: 567-571.

Ma Y, Sturrock A, Weis JJ. Intracellular localization of Borrelia burgdorferi within human endothelial cells. Infect Immun. 1991 Feb;59(2):671-8.

Magnarelli LA. Current status of laboratory diagnosis for Lyme disease. Am J Med. 1995 Apr 24;98(4A):10S-12S; discussion 12S-14S. 
Malawista SE, Montgomery RR, Wang XM, Fu LL, Giles SS. Geographic clustering of an outer surface protein A mutant of Borrelia burgdorferi. Possible implications of multiple variants for Lyme disease persistence. Rheumatology (Oxford). 2000;39(5):537-41.

Mandell H, Steere AC, Reinhardt BN, Yoshinari NH, Munsat TL. Lack of antibodies to Borrelia burgdorferi in patients with amyotrophic lateral sclerosis. N Engl J Med. 1989; 320:255-6.

Mantovani E, Costa IP, Gauditano G, Bonoldi VL, Higuchi ML, Yoshinari NH. Description of Lyme disease-like syndrome in Brazil. Is it a new tick borne disease or Lyme disease variation? Braz J Med Biol Res. 2007a Apr;40(4):443-56. Review.

Mantovani E, Gauditano G, Bonoldi VLN, Yoshinari NH. Análise clínica e sorológica de pacientes com Síndrome Infecto-Reacional Lyme-Símile. Rev Paulista de Reumatologia 2007b, 6:29.

Masters E, Granter S, Duray P, Cordes P. Physician-diagnosed erythema migrans and erythema migrans-like rashes following Lone Star tick bites. Arch Dermatol 1998;134:955-960. 
Messmer TO, Skelton SK, Moroney JF, Daugharty H, Fields BS. Application of a Nested, Multiplex PCR to Psittacosis Outbreaks. J Clin Microbiol 1997; 35 (8):2043-2046.

Miklossy J, Kasas S, Zurn AD, McCall S, Yu S, McGeer PL. Persisting atypical and cystic forms of Borrelia burgdorferi and local inflammation in Lyme neuroborreliosis. J Neuroinflammation. 2008, 25;5:40.

Mladenović J, Cekanac R, Stajković N, Krstić M. Risk of Lyme disease development after a tick bite. Vojnosanit Pregl. 2010 May;67(5):369-74.

Motaleb MA, Corum L, Bono JL, Elias AF, Rosa P, Samuels DS, Charon NW. Borrelia burgdorferi periplasmic flagella have both skeletal and motility functions. PNAS, 2000;97(20):10899-10904.

Motaleb MA, Sal MS, Charon NW. The decrease in FlaA observed in a FlaB mutant of Borrelia burgdorferi occurs posttranscriptionally. J Bacteriol. 2004;186(12):3703-11.

Murgia R, Cinco M. Induction of cystic forms by different stress conditions in Borrelia burgdorferi. APMIS. 2004 Jan;112(1):57-62. 
Onwuamaegbu ME, Belcher RA, Soare C. Cell wall-deficient bacteria as a cause of infections: a review of the clinical significance. J Int Med Res. 2005 Jan-Feb;33(1):1-20.

Oschmann P, Dorndorf W, Hornig C, Schafer C, Wellensiek HJ, Pflughaupt KW. Stages and syndromes of neuroborreliosis. J Neurol 1998; 245:262-72.

Palmer GH, Bankhead T, Lukehart SA. 'Nothing is permanent but change'antigenic variation in persistent bacterial pathogens. Cell Microbiol. 2009 Dec;11(12):1697-705.

Perez CA, Almeida AF, Almeida A, Carvalho VH, Balestrin Ddo C, Guimarães MS, Costa JC, Ramos LA, Arruda-Santos AD, Máximo-Espíndola CP, Barros-Battesti DM. Ticks of genus Amblyomma (Acari: Ixodidae) and their relationship with hosts in endemic area for spotted fever in the State of São Paulo. Rev Bras Parasitol Vet. 2008 Oct-Dec;17(4):210-7.

Pirana S, Yoshinari NH, Silveira AM, Bento RF, Bonoldi VLN. Serum reactivity for Borrelia burgdorferi, Borrelia afzelii and Borrelia garinii antigens in patients with peripheral facial paralysis in Brazil. Braz. J. Rheumatol. 2000, $40: 55-59$ 
Preac-Mursic V, Wilske B, Schierz G. European Borrelia burgdorferi isolated from humans and ticks culture conditions and antibiotic susceptibility. Zentralbl Bakteriol Mikrobiol Hyg A. 1986 Dec;263(1-2):112-8.

Purser JE, Norris SJ. Correlation between plasmid content and infectivity in Borrelia burgdorferi. PNAS 2000;97(25):13865-13870.

Rich SM, Armstrong PM, Smith RD, Telford SR 3rd. Lone star tick-infecting borreliae are most closely related to the agent of bovine borreliosis. J Clin Microbiol. 2001 Feb;39(2):494-7.)

Sadziene A, Barbour AG, Rosa PA, Thomas DD. An OspB mutant of Borrelia burgdorferi has reduced invasiveness in vitro and reduced infectivity in vivo. Infect Immun. 1993;61(9):3590-6.

Sal MS, Li C, Motalab MA, Shibata S, Aizawa SI, Charon NW. Borrelia burgdorferi uniquely regulates its motility genes and has an intricate flagellar hook basal body structure. J. Bacteriol, 2008; 190(6):1912-21.

Sato MT, SchmittA, Greboge P, Arana J, Moreira ATR, Yoshinari NH. Neurorretinite associada à ceratite intersticial: relato do primeiro caso de doença de Lyme no Estado do Paraná. Rev Bras Oftal, 2003;62:275-83. 
Shinjo SK, Gauditano G, Marchiori PE, Bonoldi VLN, Costa IP, Mantovani E, Yoshinari Y. Manifestação neurológica na Síndrome de Baggio-Yoshinari (Síndrome brasileira semelhante à doença de Lyme). Rev Bras Reumatol, 2009; 49(5)492-505.

Smith RP, Baltch AL, Ritz WJ, Carpenter AN, Halse TA, Bopp LH. In Vitro Activities of Garenoxacin and Levofloxacin against Chlamydia pneumoniae Are Not Affected by Presence of Mycoplasma DNA. Antimicrob Agents Chemother., 2004 , 48(6): 2081-2084.

Spach DH, Liles WC, Campbell GL, Quick RE, Anderson DE Jr, Fritsche TR. Tick-borne diseases in the United States. N Engl J Med. 1993 Sep $23 ; 329(13): 936-47$.

Spolidorio MG. Perfil sorológico e molecular de zoonoses transmitidas por carrapatos em humanos e animais oriundos de seis municípios do estado do Espírito Santo. [tese de doutorado], São Paulo; Faculdade de Medicina da Universidade de São Paulo, FMUSP; 2009.

Steere AC, Malawista SE, Snydman DR, Shope RE, Andiman WA, Ross MR, et al. Lyme arthritis: an epidemic of oligoarticular arthritis in children and adults in three Connecticut communities. Arthritis Rheum. 1977 JanFeb;20(1):7-17. 
Steere AC, Batsford WP, Weinberg M, Alexander J, Berger HJ, Wolfson SXMSE. Lyme carditis: cardiac abnormalities of Lyme disease. Ann. Intern. Med. 1980, 93:8-16.

Steere AC, Duray PH, Butcher EC. Spirochetal antigens and lymphoid cell surface markers in Lyme synovitis: comparison with rheumatoid synovium and tonsillar lymphoid tissue. Arthritis Rheum 1988;31:487-95.

Steere AC. Lyme disease. N Engl J Med 1989;321:586-96.

Steere AC. Lyme disease. N Engl J Med 2001; 345(2);115-25.

Steere AC, Gross D, Meyer AL, Huber BT. Autoimmune mechanisms in antibiotic treatment-resistant Lyme arthritis. J Autoimmun. 2001 May;16(3):263-8.

Stewart PE, Byram R, Grimm D, Tilly K, Rosa PA. The plasmids of Borrelia burgdorferi: essential genetic elements of a pathogen. Plasmid 2005; 53:1-13

Strle F, Nadelman RB, Cimperman J, et al. Comparison of cultureconfirmed erythema migrans caused by Borrelia burgdorferi sensu stricto in New York State and by Borrelia afzelii in Slovenia. Ann Intern Med 1999;130:32-6. 
Stromdahl EY, Williamson PC, Kollars TM JR., Evans SR, Barry RK, Vince MA, Dobbs NA. Evidence of Borrelia lonestari DNA in Amblyomma americanum (Acari: Ixodidae) removed from humans. J Clin Microbiol. 2003 ;41(12):5557-62.

Swartz SL, Kraus SJ. Persistent urethral leukocytosis and asymptomatic chlamydial urethritis. J Infect Dis. 1979 Oct;140(4):614-7.

Szabó MPJ, Cunha M, Santos AP, Vicentini F. Ticks (Acari: Ixodidae) associated with domestic dogs in Franca region, São Paulo, Brazil. Experimental andApplied Acarology,2001;. 969 (25):290-293.

Thomas DD, Comstock LE. Interaction of Lyme disease spirochetes with cultured eucaryotic cells. Infect Immun. 1989 Apr;57(4):1324-6.

Tilly K, Krum JG, Bestor A, Jewett MW, Grimm D, Bueschel D, Byram R, Dorward D, Vanraden MJ, Stewart P, Rosa P. Borrelia burgdorferi OspC protein required exclusively in a crucial early stage of mammalian infection. Infect Immun. 2006 Jun;74(6):3554-64.

Tuuminen T, Varjo S, Ingman H, Weber T, Oksi J, Viljanen M. Prevalence of Chlamydia pneumoniae and Mycoplasma pneumoniae immunoglobulin G 
and $\mathrm{A}$ antibodies in a healthy Finnish population as analyzed by quantitative enzyme immunoassays. Clin Diagn Lab Immunol. 2000 Sep;7(5):734-8.

Varela AS, Luttrell MP, Howerth EW, Moore VA, Davidson WR, Stallknecht DE, Little SE. First culture isolation of Borrelia lonestari, putative agent of southern tick-associated rash illness. J Clin Microbiol. 2004 Mar;42(3):11639.

Wang G, Van Dam AP, Schwartz I, Dankert J. Molecular typing of Borrelia burgdorferi sensu lato: taxonomic, epidemiological, and clinical implications. Clin Microbiol Rev. 1999;12(4): 633-653.

Yang X, Goldberg MS, Popova TG, Schoeler GB, Wikel SK, Hagman KE, Norgard MV. Interdependence of environmental factors influencing reciprocal patterns of gene expression in virulent Borrelia burgdorferi. Mol Microbiol. 2000 Sep;37(6):1470-9.

Yoshinari NH, Steere AC, Cosermelli W. Revisão da borreliose de Lyme. Rev Assoc Med Brasil, 1989; 35(1):34-8.

Yoshinari NH, Barros PJL, Cruz FCM, Oyafuso LK, Mendonça M, Baggio D, et al. Clínica e sorologia da doença de Lyme no Brasil. Rev Bras Reumatol (Supl)1992; 32:57. 
Yoshinari NH, Barros PJL, Fonseca AH, Bonoldi VL, Barros-Battesti DM. Borreliose de Lyme. Zoonose emergente de interesse multidisciplinar. Newslab. 1995; 12:90-104.

Yoshinari NH, Barros PJL, Bonoldi VLN. Perfil da borreliose de Lyme no Brasil. Rev Hosp Clin Fac Med S Paulo. 1997a; 52:111-17.

Yoshinari NH, de Barros PJ, Bonoldi VLN, Ishikawa M, Battesti DM, Pirana S, et al. Outline of Lyme borreliosis in Brazil. Rev Hosp Clin Fac Med São Paulo 1997b; 52:111-117.

Yoshinari NH, Barros PJL, Gauditano G, Fonseca AH. Report of 57 cases of Lyme-like disase (LLD) in Brazil. Arthritis Rheum. (Suppl) 1999a; 43:S188.

Yoshinari NH, Bonoldi VLN, Barros-Battesti DM, Schumaker TTS. Doença de Lyme-símile no Brasil. Rev Bras Reumatol. 1999b; 39(2):57-8.

Yoshinari NH, Abrão MG, Bonoldi VL, Soares CO, Madruga CR, Scofield A, et al. Coexistence of antibodies to tick-borne agents of babesiosis and Lyme borreliosis in patients from Cotia county, State of São Paulo, Brazil. Mem Inst Oswaldo Cruz. 2003 Apr;98(3):311-8. 
Yoshinari NH, Spolidorio M, Bonoldi VL, Sotto M. Lyme disease like syndrome associated lymphocytoma:first case report in Brazil. Clinics (Sao Paulo), 2007 Aug;62(4):525-6.

Yoshinari NH, Vasconcelos AS, Tiriba AC, Gauditano G, Mantovani E, Bonoldi VLN. Report $\mathrm{n}$ the unusual presence of latent microorganisms in animals: a risk to research and health of employees? Bras $J$ Rheumatol 2009; 49(5):517-28.

Young KD. Reforming L forms: they need part of a wall after all? J Bacteriol. 2007 Sep;189(18):6509-11.

Yparraguirre LA, Machado-Ferreira E, Ullmann AJ, Piesman J, Zeidner NS, Soares CA. A hard tick relapsing fever group spirochete in a Brazilian Rhipicephalus (Boophilus) microplus. Vector Borne Zoonotic Dis. $2007 ; 7(4): 717-21$. 
10. Apêndices 


\subsection{Comprovante de submissão do artigo para publicação}

The NEW ENGLAND

JOURNAL of MEDICINE

Main Menu $\rightarrow$ Author Dashboard $\rightarrow$ Submission Confirmation

Submission

Confirmation
Edit Account | Instructions \& Forms | Log Out | Get Melp Now

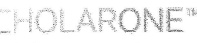

Manuscriots

You are logged in as Elenice Mantovani

Thank you for submitting your manuscript to New England Journal of Medicine.

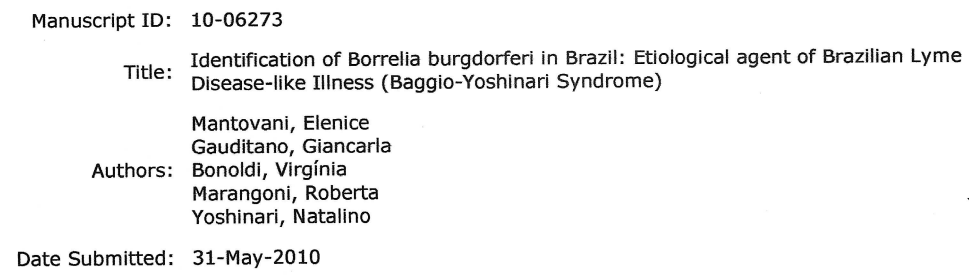




\subsection{Artigo para publicação}

Submitted to the New England Journal of Medicine

\section{The NEW ENGLAND \\ JOURNAL of MEDICINE}

Please review the Supplemental Files folder to review documents not compiled in the PDF.

\section{Identification of Borrelia burgdorferi in Brazil: Etiological agent of Brazilian Lyme Disease-like Illness (Baggio- Yoshinari Syndrome)}

\begin{tabular}{|c|c|}
\hline Journal: & New England Journal of Medicine \\
\hline Manuscript ID: & Draft \\
\hline Article Type: & Original Article \\
\hline $\begin{array}{l}\text { Date Submitted by the } \\
\text { Author: }\end{array}$ & $n / a$ \\
\hline Complete List of Authors: & $\begin{array}{l}\text { Mantovani, Elenice; Faculdade de Medicina da Universidade de São } \\
\text { Paulo, Disciplina de Reumatologia } \\
\text { Gauditano, Giancarla; Faculdade de Medicina da Universidade de } \\
\text { São Paulo, Disciplina de Reumatologia } \\
\text { Bonoldi, Virgínia; Faculdade de Medicina da Universidade de São } \\
\text { Paulo, Disciplina de Reumatologia } \\
\text { Marangoni, Roberta; Faculdade de Medicina da Universidade de São } \\
\text { Paulo, Disciplina de Reumatologia } \\
\text { Yoshinari, Natalino; Faculdade de Medicina da Universidade de São } \\
\text { Paulo, Disciplina de Reumatologia }\end{array}$ \\
\hline Keywords: & $\begin{array}{l}\text { Infectious Disease, Bacterial Infections }<\text { Infectious Disease, } \\
\text { Infection-related Disease }<\text { Rheumatology }\end{array}$ \\
\hline Abstract: & $\begin{array}{l}\text { Introduction: Baggio-Yoshinari Syndrome (BYS) is a new tick-borne } \\
\text { infection discovered in Brazil, similar to Lyme Disease (LD) } \\
\text { described in the Northern Hemisphere, except for essential } \\
\text { differences in epidemiological, clinical and laboratorial findings. } \\
\text { Objectives: To identify the etiologic agent of BYS using a conserved } \\
\text { gene that synthesizes the flagellar hook (flgE) of Borrelia } \\
\text { buradorferi sensu lato by molecular typina method based on } \\
\text { polymerase chain reaction (PCR). } \\
\text { Methods: Eight patients fulfilling the BYS diagnostic criteria were } \\
\text { recruited from } 2008 \text { to October } 2009 \text {. The patients presented } \\
\text { erythema migrans and positive epidemiologic history. Thirty } \\
\text { healthy individuals, without tick bite history or risk areas exposure, } \\
\text { were included in the control group. Blood samples were collected } \\
\text { and stored at }-20^{\circ} \mathrm{C} \text {. The DNA was extracted by commercial Kits } \\
\text { and the PCR assay was performed targeting a portion of the gene } \\
\text { flgE followed by sequence analysis. } \\
\text { Results: From the } 8 \text { patients selected for this study, } 4 \text { (50\%) } \\
\text { amplified DNA when targetina the qene flaE } 470 \text { pb (GenBank } \\
\text { accession HM } 245929 \text { ). These positive samples when sequenced, } \\
\text { revealed a } 99 \% \text { homology to Borrelia burgdorferi flagellar hook }\end{array}$ \\
\hline
\end{tabular}


1

2 ecologic conditions.

\section{S ScholaroNE" \\ Manuscript Central}

Confidential: Destroy when review is complete.

Conclusions: By the first time, we have identified $B$. burgdorferi in Brazil, perhaps in the Southern Hemisphere, usina a specific primer derived from flagellar hook (flgE) gene. Other primers usually employed in Northern hemisphere to diagnose LD had failed in Brazil, since etiological agent seems to be found at atypical morpholoay (cysts). We assume that $\mathrm{B}$. burqdorferi can cause different disease expressions when under diverse geographic and 


\section{Introduction}

Baggio-Yoshinari Syndrome (BYS) is a new Brazilian zoonosis that resembles clinical and laboratorial aspects of the classic Lyme disease (LD) described in North America and Eurasia. Previously, this emerging zoonosis was called Brazilian Lyme disease-like illness or Infectious reactive Lyme-like illness. ${ }^{1,2}$

The eponym BYS was created in an attempt to distinguish it completely from LD. It is noteworthy that $I$. ricinus complex ticks infected by Borrelia burgdorferi spirochetes had never been found in Southern Hemisphere, and typical cases of LD had never been described in this part of the world. ${ }^{3,4}$

BYS exhibits classic LD skin lesions, and systemic osteoarticular, neurological and cardiac symptoms as the disease progresses. However, the main distinguishing feature of the BYS is the occurrence of clinical relapsing symptoms, especially when diagnosis and appropriate therapy are delayed. Importantly, ticks belonging to Ixodes ricinus complex that accidentally bites humans were never identified at risk areas for BYS. ${ }^{5-7,10-13}$

B. burgdorferi, the LD etiological agent, had never been cultivated in BSK medium when using samples from BYS patients, neither from ticks and reservoir animals. Furthermore, the specific serologic tests (ELISA and Western blotting) to demonstrate antibodies to $B$. burgdorferi sensu lato of North American or European origins have shown low sensitivity when applied in Brazilian patients' samples. Furthermore, patients with BYS develop autoimmune or allergic phenomena with appearance of antinuclear, anticardiolipin, antineutrophil cytoplasmic, antineuronal antibodies, and increased serum immunoglobulin E levels. ${ }^{11,13-16}$

Previous molecular studies (PCR) demonstrated by Costa et al (2001) and Barros (2000) revealed negative results, when primers to amplify conservative genes specific to $B$. burgdorferi as outer surface protein A (OspA), or genes for 
flagella filament (major flagellin FlaB, and minor flagellin FlaA), as well as for ribosomal protein (16S rRNA) were employed. ${ }^{17-21}$

After all, due to existence of many similarities between BYS and LD, we decided to target other preserved genes, necessary for Borrelia infection and survival among different vertebrate and invertebrate hosts. The first targeted gene belonged to cp32 plasmid group, that were found preserved in the majority of $B$. burgdorferi strains. PCR carried out with these genes has failed, since samples couldn't be sequenced, due to strong homology with human DNA. After that, we researched genes Ip 25 and $\mathrm{lp} 28-1$, which are important for Borrelia virulence and infectivity, but the results were also negative. ${ }^{22-24}$

The study of another gene emerged after careful analysis of western blotting (WB) performed in Brazilian patients' samples. We observed that almost all cases had $41 \mathrm{Kda}$ antibodies directed to periplasmic flagella components. This fact has surprised us, since previous PCR studies with primers employed to recognize FlaA and FlaB filaments revealed negative results. Reviewing published scientific articles, we understood that periplasmic flagella were composed by different components like a basal body, a hook regulated by flgE gene and flagellar filaments formed by FlaA and FlaB proteins. Based on these studies, a new primer involving synthesis of the flagellar hook (flgE) was designed and tested. ${ }^{25-27}$

The aim of the present study is to show that PCR targeting the flgE gene, allowed us to identify the etiological agent of BYS, and also, to show the importance of this primer to diagnose first cases of patients infected by $B$. burgdorferi spirochetes in the South America, and perhaps in Southern Hemisphere.

\section{Patients and Methods}




\section{a) Patients}

We selected 8 BYS diagnosed patients from November 2008 through October 2009 , being five female and three male, with a mean age of $41.6( \pm 22.8)$ years. All the patients presented erythema migrans (EM) and had positive epidemiologic history. Half of patients had been bitten by tick and seven of then presented flu-like symptoms like fever, headache, myalgia, artralgia, chills and fatigue (Table 1). All patients fulfilled Brazilian diagnostic criteria for BYS. ${ }^{2}$

Five patients were in the acute stage (less than 90 days) and 3 were in the latent stage (more than three months after initial epidemiologic history). Three patients from latent stage developed arthritis and four were taking antibiotics at the time of blood samples collection (Table 2). Only three (37.5\%) subjects had positive serology for B. burgdorferi G39/40 of North American origin (ELISA or WB according to Brazilian standardization) (Table 2). ${ }^{13,28}$

Thirty healthy individuals, without tick bite history or attending visit to highrisk areas, were included in the control group. They were 19 female (63.3\%) and 11 male $(36.7 \%)$ with mean age of $38.1( \pm 9)$ years.

The study was approved by the Ethics Committee in Research, CAPPesq of the Clinical Board of the School of Medicine, University of Sâo Paulo, as stated in Protocol of Research number 0895/05. All patients and controls performed informed written consent.

\section{b) Methods}

DNA was extracted using the QIAamp®) DNA Blood Midi Kit (Qiagen $\mathrm{GmbH}$ ) from $2 \mathrm{~mL}$ of peripheral blood of patients, following the manufacturer's procedures.

We performed PCR targeting the gene flgE (Sal et al., 2008 - modified) where we used the primers: flgE $470 \mathrm{FW}$ (5'-CGCCTATTCTAACTTGACCTGAAT 


\section{- 3 ') and flgE 470 Rev \\ (5'- TTAGTGTTCTTGAGCTTAGAGTTG - 3') \\ A second}

reaction was performed with the same primer of the first reaction, in order to obtain a larger amount of DNA. ${ }^{27}$

PCR reaction was performed with a mix containing 5 pmoles of each primer, Tris- $\mathrm{HCl} 10 \mathrm{mM}, \mathrm{MgCl} 21.5 \mathrm{mM}$, dNTP mix $1.25 \mathrm{mM}$, TaqDNA polymerase $1.5 \mathrm{U}$, $\mathrm{H}_{2} \mathrm{O}$ DNAse/RNAse free and $5 \mu \mathrm{l}$ of the DNA sample. $1.5 \mu \mathrm{l}$ of DMSO was added right before cycling ( $3 \%$ final concentration). For the second reaction we used $0.5 \mu \mathrm{l}$ of the amplified PCR product obtained from the first reaction.

PCR cycle conditions consisted of a initial denaturation for 3 min at $95^{\circ} \mathrm{C}$, and 35 repetitive cycles of $45 \mathrm{~s}$ at $95^{\circ} \mathrm{C}, 45 \mathrm{~s}$ at $64^{\circ} \mathrm{C}, 45 \mathrm{~s}$ at $72^{\circ} \mathrm{C}$ for $45 \mathrm{~s}$, followed by a final extension for $7 \mathrm{~min}$ at $72^{\circ} \mathrm{C}$. Good laboratory practice to avoid contamination was always followed, and in every reaction we also included one negative control to check for possible contamination, and B. garinii was used as a positive control in all reactions. PCR products were eletrophoresed through a $1.5 \%$ agarose gel, stained with SYBR Gold (Invitrogen) and examined by UV transillumination.

Positive samples were purified with the QIAEX ${ }^{\circledR}$ II Gel Extraction Kit (Qiagen $\mathrm{GmbH}$ ) and sequencing of genomic regions was performed with the BigDye Terminator Cycle Sequencing kit, version 3.1 (Applied Biosystems), and the ABI Prism 3730 DNA analyzer (Applied Biosystems). Partial sequences obtained were submitted to BLAST analysis to determine the closest similarities to corresponding sequences. ${ }^{29}$

\section{$\underline{\text { Results }}$}

PCR targetting the gene flgE, which amplifies a fragment of $\approx 470 \mathrm{pb}$ showed positivity in 4 samples (50\%) (patients JS, ORG, PMCB and ABPLS) 
(Figure 1). Sequences disclosed a similarity of $99 \%$ to B. burgdorferi flagellar hook protein (flgE) gene (L43849).

We decided to sequence $B$. garinii, so that we could compare the homology of this control to B. burgdorferi, and our positive control presented $94 \%$ of homology to B. burgdorferi flagellar hook protein (flgE) gene (L43849) and only $92 \%$ homology for the sequence of the BYS patients' samples. All samples of the control group were negative for the primers used in this study.

Partial sequences (flgE 470) of Borrelia burgdorferi flagellar hook protein generated in this study were deposited into GenBank and assigned nucleotide accession no. HM245929.

\section{Discussion}

Baggio-Yoshinari Syndrome has been investigated in Brazil since 1989 by Yoshinari and colleagues and complete understanding of zoonosis has been an enormous challenge to Brazilian researchers, due to many distinguishing features between BYS and LD. The first Brazilian cases were identified in 1992, in young brothers from Cotia County, Sâo Paulo State. ${ }^{30,31}$

Brazilian patients had frequent relapsing symptoms, low serologic immune response to $B$. burgdorferi sensu lato antigens and etiological agent had never been isolated. For these reasons, and also to facilitate the outspread of knowledge to Brazilian physicians, this new tick borne disease was named Baggio-Yoshinari Syndrome.

Our results confirm that BYS is also caused by a spirochete belonging to B.burgdorferi sensu lato complex, and the first description of B.burgdorferi identification in Southern Hemisphere. It was possible due to the development of a pair of primers derived from de conservative gene flgE. This gene is formed of 
1119 nucleotides and it is responsible for synthesis of flagella hook structure. When sequenced, the Brazilian B. burgdorferi revealed $99 \%$ of homology to $B$. burgdorferi sensu stricto and $92 \%$ with Borrelia garinii. This unexpected result indicated that etiological agent of BYS, despite of all commented particularities, is a spirochete similar to those found in Northern Hemisphere.

In the current study, we chose to test the importance of this primer as a diagnostic tool, performing PCR in a homogenous group of BYS patients, with typical EM and positive epidemiological history. From the 8 studied subjects, four (50\%) were positive, two of them at acute stage and two at latent stage complicated with arthritis.

Of these patients at latent stage, one was a 60-years-old man (ORG) who acquired infection in the Amazon Forest and presented EM at tick bite site associated to flu like symptoms. At that time, he was diagnosed for BYS and treated with doxycycline $100 \mathrm{mg}$ twice a day for 15 days. After about 8 months he presented knee arthritis and was investigated again for SBY, when PCR result confirmed infection for $B$. burgdorferi.

The other positive patient was an eleven-years-old boy (PMCP), who underwent exposition at risk areas in a beach city named Ubatuba, State of São Paulo, localized in Atlantic Forest. He presented EM in the left cheer associated to flu-like symptoms and arthralgia. At that time, he was not diagnosed nor treated. After 5 months, the boy presented arthritis of the knees, elbow and hands, when was treated with benzatine penicillin without any benefit. After four months, diagnosis of BYS was achieved, after performing PCR test with flgE primer in our laboratory

In Brazil, differently from LD, the patients are classified in acute stage, when zoonosis is discovered within three months following tick bite episode or in latent disease stage if diagnosis happens after this period of time. Patients who were not 
treated at acute stage or when diagnosed at latent stage, present relapsing symptoms in $75 \%$ of the cases. This feature explains why BYS, in general, are discovered only at latent stage of disease. Unfortunately, Brazilian physicians are not accustomed to identify BYS, since typical EM is present in less than $50 \%$ of individuals at acute stage, and patients at this stage do not remember epidemiological data happened many time ago. $7,10,17$

Important understandings concerning etiological agent of BYS, were obtained by electron microscopy analysis (ME), when Mantovani et al. ${ }^{2}$ described structures resembling Mycoplasma spp, Chlamydia spp and long bacterium-like microorganisms in the peripheral blood of patients. Since the serologic and PCR tests haven't confirmed infections for these latent microorganisms, and supported by the fact that spirochetes had never been cultivated or isolated in Brazil, we suggested that etiological agent of BYS could be expressed at these atypical morphologies. In addition, we had proven that spirochete-like structures had preserved the property to invade endothelial cells culture in vitro. ${ }^{32}$

Medical Literature review states that the majority of bacteria at inadequate survivor conditions, can lose its outer membrane components to assume Mycoplasma morphology. These modified bacteria are known as spheroplasts, Lform or cell wall deficient bacteria (CWDB). Spirochetes of genera Treponema and Borrelia also change its morphology to CWDB and they used to return to original helical shape after disappearance of triggering factors. ${ }^{33-40}$

Furthermore, spirochetes cultivated in adverse conditions of $\mathrm{pH}$, temperature or antibiotics presence can develop other structural modifications, as those resembling very little points or spores called blebs, bacterium-simile structures without flagella or double membrane dense bodies imitating Chlamydia. Also, spirochetes with atypical morphology have been described in tissues of patients with syphilis and borreliosis. ${ }^{41-45}$ 
Our previous studies on microbiology showing that: spirochete is uncultivable; Molecular Biology demonstrating incompetence of flagelin and OspA primers to identify Brazilian B. burgdorferi; Electron microscopy evidencing presence of microorganisms at atypical morphologies; Clinical findings showing relapsing symptoms and Serology demonstrating low immune responses of BYS, support the hypothesis that BYS is caused by morphologically atypical $B$. burgdorferi sensu lato.

We never recovered B. burgdorferi at its typical helical shape in Brazil, even when different biological samples from patients (blood, skin biopsies, cerebrospinal fluid), ticks and blood samples from potential reservoir animals were cultured in BSK medium or other improved media, suggesting that atypical spirochetes were possibly irreversible in Brazil. We assume that genes for synthesis of periplasmic flagella and part of Osps were lost forever. Interestingly, Borrelia motility and morphology are given by periplasmic flagella, while lipoproteins of outer surface membrane (Osp) are main components of the external cell wall. Bactericidal antibodies and antibiotics, are in general, directed to determinants localized in the outer membrane of the spirochetes, justifying why the causative agent of BYS, escapes from immunological surveillance and antibiotic treatment, causing $B$. burgdorferi persistence, relapsing symptoms and prolonged disease. ${ }^{27,46}$

At present, BYS is defined as a new and emergent Brazilian infectious disease, caused by $B$. burgdorferi sensu lato at its atypical morphology, transmitted by ticks not belonging to Ixodes ricinus complex, which originates clinical manifestations resembling classic LD, except for high frequency of recurrent symptoms.

We believe that appearance of $B$. burgdorferi at its atypical morphology can be related to absence of Ixodes ricinus complex ticks, that accidentally bites 
humans, at researched risk areas in the country. In this sense, we have observed appearance of EM following accidental bite by Amblyomma cajennense tick specie in Brazil. ${ }^{16}$

All species of ticks transmitting LD in North America and Eurasia belong to Ixodes genera. There are many molecular interactions between B.burgdorferi and ticks and mammalian hosts, especially those concerning expression or suppression of lipoproteins of external membrane as Osp A, B, C, D, E and F. For example, expression of regulatory genes for glycoproteins TROSPA and salp 15 by Ixodes ricinus are of critical relevance for Borrelia survival inside ticks and very relevant for microorganisms transmission among different hosts. ${ }^{47-49}$

B. burgdorferi also exhibits an important adaptive process after infecting mammal hosts, demonstrated by an increased expression of OspC and inhibition of OspA proteins. B. burgdorferi also adopts molecular survival strategies to escape from host immune response, changing its genetic profile and proteins repertoire. The OspE lipoprotein synthesized by Borrelia has an important role by binding to factor $\mathrm{H}$, inhibiting the alternative complement activation pathway and avoiding bacteria killing by mammalian host. In other words, the virulence of $B$. burgdorferi infection depends on its capacity to infect, to suppress or activate genes repertoire, to invade distant tissues and finally to escape from host immunological vigilance. ${ }^{47,50-56}$

We suggest that, the main causative factor for emergence of atypical morphologies of $B$. burgdorferi in Brazil is related to absence of Ixodes ricinus complex ticks. This tick genus occurs in Brazil, but not biting people at researched risk areas. It is plausible that, Brazilian geographic conditions and fauna biodiversity, had contributed to originate genetically modified spirochetes, adapted to survive at environmental conditions found in our country. In USA, it is described 
mutations of different B. burgdorferi genes as those related to OspA, OspB, OspC, lipoproteins Osp and flagella. ${ }^{49,51,56-64}$

Where did Brazilian B. burgdorferi come from? According to Margos et al., who performed a multilocus sequence typing (MLST) scheme for B.burgdorferi, based on chromosomal housekeeping genes, the spirochete probably originated from Europe despite of United States of America. We assume that Brazilian Borrelia came possibly from Europe. ${ }^{65}$

In conclusion, by the first time, we identified B. burgdorferi in South America and possibly in Southern hemisphere. We also conclude that spirochete $B$. burgdorferi can cause two different clinical entities, Lyme disease in United States of America and Eurasia and Baggio-Yoshinari Syndrome in Brazil. This amazing phenomenon, never described before, is possibly related to the fantastic power of B. burgdorferi to adopt molecular survival strategies to adjust at different environmental conditions found around the world.

\section{Acknowledgments}

We thank the Discipline of Oncology, FMUSP (LIM -24), especially the employees Flavia Regina Rotea Mangone and Fatima Solange Pasini, which allowed to reach the primers used.

Prof. Dr. Marcelo Bahia Labruna (FMVZ-USP) for helping with the analysis of sequences.

This work was supported by Fundação de Amparo a Pesquisa do Estado de São Paulo (FAPESP), grant $n^{\circ} 05 / 56166-8$, and also for the schoolarship support to Mantovani E (grant n $06 / 54837-5$ ).

\section{References}

1- Steere AC. Lyme disease. N Engl J Med 1989; 321(9):586-96. 
2- Mantovani E, Costa IP, Gauditano G, Bonoldi VL, Higuchi ML, Yoshinari NH. Description of Lyme disease-like syndrome in Brazil. Is it a new tick borne disease or Lyme disease variation? Braz J Med Biol Res. 2007;40(4):443-56.

3- Pachner AR, Steiner I. Lyme neuroborreliosis: infection, immunity and inflammation. Lancet Neurol. 2007: 6:544-552.

4- Kurtenbach K, Hanincová K, Tsao Jl, Margos G, Fish D, Ogden NH. Fundamental processes in the evolutionary ecology of Lyme Borreliosis. Nat. Rev. Microbiol. 2006; 4:660-69.

5- Barros PJL, Levy LH, Monteiro FG, Yoshinari NH. Lyme disease: cutaneous involvement and treatment of the initial phases. Rev. Assoc. Med. Bras. 1993; 39:170-72.

6- Yoshinari N, Spolidorio M, Bonoldi VL, Sotto M. Lyme disease like syndrome associated lymphocytoma: First case report in Brazil. Clinics. 2007, 62:525-6.

7- Yoshinari NH, Barros PJL, Bonoldi VLN, Ishikawa M, Battesti DM, Pirana S, Fonseca AH, Schumaker TT. Outline of Lyme borreliosis in Brazil. Rev Hosp Clin Fac Med S Paulo. 1997; 52:111-17.

8- Yoshinari NH, Barros PJL, Gauditano G, Fonseca AH. Report of 57 cases of Lyme-like disease (LLD) in Brazil. Arthritis Rheum. (Suppl) 1999; 43:S188.

9- Lorenzi MC, Bittar RS, Pedalini ME, Zerati F, Yoshinari NH, Bento RF. Sudden deafness and Lyme disease. Laryngoscope. 2003, 113(2):312-5.

10- Shinjo SK, Gauditano G, Marchiori PE, et al. Neurological manifestations in Baggio-Yoshinari Syndrome (Brazilian Lyme disease-like syndrome). Braz J Rheumatol, 2009; 49(5)492-505.

11- Yoshinari NH, Barros PJL, Fonseca AH, Bonoldi VL, Barros-Battesti DM. Borreliose de Lyme. Zoonose emergente de interesse multidisciplinar. Newslab. $1995 ; 12: 90-104$

12- Barros-Battesti DM, Yoshinari NH, Bonoldi VLN, Gomes AC. Parasitism by Ixodes didelphidis and I. Ioricatus (Acari: Ixodidae) on Small Wild Mammals from an Atlantic Forest in the State of Sao Paulo, Brazil. J Med Entomol. 2000; 37 (6): 820-827.

13- Costa IP, Bonoldi VLN, Yoshinari NH. Search for Borrelia sp. in ticks collected from potential reservoirs in an urban forest reserve in the state of Mato Grosso do Sul, Brazil: a Short Report. Mem Inst Oswaldo Cruz. 2002; 97(5):631-635.

14- Abel IS, Marzagão G, Yoshinari NH, Schumaker TT. Borrelia-like spirochetes recovered from ticks and small mammals collected in the Atlantic Forest Reserve, Cotia county, State of São Paulo, Brazil. Mem Inst Oswaldo Cruz. 2000; 95(5):621-4 
15- Pirana S, Yoshinari NH, Silveira AM, Bento RF, Bonoldi VLN. Serum reactivity for Borrelia burgdorferi, Borrelia afzellii and Borrelia garinii antigens in patients with peripheral facial paralysis in Brazil. Braz. J. Rheumatol. 2000, 40:55-59

16- Gauditano G \& Yoshinari NH. Doença de Lyme/Síndrome de BaggioYoshinari. In: Veronesi, R.; Focaccia, R. Tratado de Infectologia. $4^{a}$ ediçāo. Sāo Paulo. Editora Atheneu. 2009, 1359-1379.

17- Costa IP, Bonoldi VLN, Yoshinari NH. Clinical and laboratorial outline of Lyme-like disease, in Mato Grosso do Sul State:analysis of 16 patients. Braz. J. Rheumatolol. 2001, 41(3):142-150.

18- Barros PJL. Caracterizaçāo clínica e laboratorial da doença de Lyme no Brasil, através de métodos imunológicos e reação em cadeia de polimerase. [tese de doutorado], São Paulo: Faculdade de Medicina da Universidade de São Paulo, FMUSP; 2000.

19- Liebling MR, Nishio MJ, Rodriguez A, Sigal LH, Jin T, Louie JS. The polymerase chain reaction for the detection of Borrelia burgdorferi in human body fluids. Arthritis Rheum. 1993;36(5):665-75.

20- Kawabata H, Tashibu H, Yamada K, Masuzawa T, Yanagihara Y. Polymerase chain reaction analysis of Borrelia species isolated in Japan. Microbiol Immunol. $1994 ; 38(8): 591-8$.

21- Barbour AG, Maupin GO, Teltow GJ, Carter CJ, Piesman J. Identification of an uncultivable Borrelia species in the hard tick Amblyomma americanum: possible agent of a Lyme disease-like illness. J Infect Dis. 1996;173(2):403-9.

22- Stewart PE, Byram R, Grimm D, Tilly K, Rosa PA. The plasmids of Borrelia burgdorferi: essential genetic elements of a pathogen. Plasmid 2005; 53:1-13.

23- Purser JE, Norris SJ. Correlation between plasmid content and infectivity in Borrelia burgdorferi. PNAS. 2000;97(25):13865-13870.

24- lyer R, Kalu O, Purser J, Norris S, Stevenson B, Schwartz I. Linear and circular plasmid content in Borrelia burgdorferi clinical isolates. Infect Immun. 2003;71(7):3699-706.

25- Barbour AG, Hayes SF. Biology of Borrelia species. Microbiol. 1986, Rev.50:381-400.

26- Ge Y, Old IG, Saint Girons I, Charon NW. Molecular characterization of a large Borrelia burgdorferi motility operon which is initiated by a consensus $\sigma 70$ promoter. J Bacteriol. 1997; 179:2289-99.

27- Sal MS, Li C, Motalab MA, Shibata S, Aizawa SI, Charon NW. Borrelia burgdorferi uniquely regulates its motility genes and has an intricate flagellar hook basal body structure. J. Bacteriol. 2008; 190(6):1912-21.

28- Yoshinari NH, Abrāo MG, Bonoldi VLN, et al. Coexistence of antibodies to tickborne agents of babesiosis and Lyme Borreliosis in patients from Cotia Country, State of Sâo Paulo, Brazil. Mem Inst Oswaldo Cruz. 2003; 98(3): 311-18. 
29- Altschul SF, Gish W, Miller W, Myers EW, Lipman DJ. Basic local alignment search tool. J Mol Biol. 1990;215:403-10.

30- Yoshinari NH, Steere AC, Cossermelli W. A review of Lyme disease. Rev Assoc Med Bras. 1989; 35(1): 34-8.

31- Yoshinari NH, Barros PJL, Cruz FCM, et al. Clínica e sorologia da Doença de Lyme no Brasil. Rev Bras Reumatol 1992; 32(supl):57.

32- Yoshinari NH, Vasconcelos AS, Tiriba AC, Gauditano G, Mantovani E, Bonoldi VLN. Report of unusual presence of latent microorganisms in animals: a risk to research and health of employees? Braz J Rheumatol 2009; 49(5):517-28.

33- Charache P. Cell wall-defective bacterial variants in human disease. Ann N Y Acad Sci 1970; 174: $903-911$.

34- Domingue GJ Sr, Woody HB. Bacterial persistence and expression of disease. Clin Microbiol Rev. 1997;10(2):320-44.

35- Butler HM, Blakey JL. A review of bacteria in L-phase and their possible clinical significance. Med J Aust. 1975;2(12):463-7.

36- Young KD. Reforming L forms: they need part of a wall after all? J Bacteriol. 2007 Sep;189(18):6509-11.

37- Allan EJ, Hoischen C, Gumpert J. Bacterial L-forms. Adv Appl Microbiol. 2009;68:1-39.

38- Mursic VP, Wanner G, Reinhardt S, Wilske B, Busch U, Marget W. Formation and cultivation of Borrelia burgdorferi spheroplast-L-form variants. Infection. $1996 ; 24(3): 218-26$

39- Ovcinnikov NM, Delektorskij VV. Current concepts of the morphology and biology of Treponema pallidum based on electron microscopy. $\mathrm{Br} \mathrm{J}$ Vener Dis. 1971;47(5):315-28.

40- Brorson O, Brorson SH. A rapid method for generating cystic forms of Borrelia burgdorferi, and their reversal to mobile spirochetes. APMIS.1998;106(12):113141.

41- Kersten A, Poitschek C, Rauch S, Aberer E. Effects of penicillin, ceftriaxone, and doxycycline on morphology of Borrelia burgdorferi. Antimicrob Agents Chemother. 1995;39(5):1127-33.

42- Murgia R, Cinco M. Induction of cystic forms by different stress conditions in Borrelia burgdorferi. APMIS. 2004;112(1):57-62.

43- Astrauskiene D, Bernotiene E. New insights into bacterial persistence in reactive arthritis. Clin Exp Rheumatol. 2007;25(3):470-9. 
44- Miklossy J, Kasas S, Zurn AD, McCall S, Yu S, McGeer PL. Persisting atypical and cystic forms of Borrelia burgdorferi and local inflammation in Lyme neuroborreliosis. J Neuroinflammation. 2008, 25;5:40.

45- Duray PH, Yin SR, Ito Y, et al. Invasion of human tissue ex vivo by Borrelia burgdorferi. J Infect Dis. 2005;191(10):1747-54.

46- Motaleb MA, Corum L, Bono JL, et al. Borrelia burgdorferi periplasmic flagella have both skeletal and motility functions. PNAS. 2000;97(20):10899-10904.

47- Krupka M, Raska M, Belakova J, Horynova M, Novotny R, Weigl E. Biological aspects of Lyme disease spirochetes: unique bacteria of the Borrelia burgdorferi species group. Biomed Pap Med Fac Univ Palacky Olomouc Czech Repub. $2007 ; 151(2): 175-86$

48- Hovius JW, van Dam AP, Fikrig E. Tick-host-pathogen interactions in Lyme borreliosis. Trends Parasitol. 2007;23(9):434-8.

49- Derdáková M, Lencáková D. Association of genetic variability within the Borrelia burgdorferi sensu lato with the ecology, epidemiology of Lyme borreliosis in Europe. Ann Agric Environ Med. 2005; 12:165-172.

50- Tilly K, Krum JG, Bestor A, et al. Borrelia burgdorferi OspC protein required exclusively in a crucial early stage of mammalian infection. Infect Immun. 2006;74(6):3554-64.

51- Yang X, Goldberg MS, Popova TG, et al. Interdependence of environmental factors influencing reciprocal patterns of gene expression in virulent Borrelia burgdorferi. Mol Microbiol. 2000;37(6):1470-9.

52- Singh SK, Girschick HJ. Molecular survival strategies of the Lyme disease spirochete Borrelia burgdorferi. Lancet Infect Dis. 2004;4(9):575-83.

53- Barbour AG, Dai Q, Restrepo BI, Stoenner HG, Frank SA. Pathogen escape from host immunity by a genome program for antigenic variation. Proc Natl Acad Sci U S A. 2006; 103(48):18290-5.

54- Xu Q, Seemanapalli SV, McShan K, Liang FT. Constitutive expression of outer surface protein $\mathrm{C}$ diminishes the ability of Borrelia burgdorferi to evade specific humoral immunity. Infect Immun. 2006;74(9):5177-84.

55- Palmer GH, Bankhead T, Lukehart SA. 'Nothing is permanent but change'antigenic variation in persistent bacterial pathogens. Cell Microbiol. 2009;11(12):1697-705.

56- Malawista SE, Montgomery RR, Wang XM, Fu LL, Giles SS. Geographic clustering of an outer surface protein A mutant of Borrelia burgdorferi. Possible implications of multiple variants for Lyme disease persistence. Rheumatology (Oxford). 2000;39(5):537-41.

57- Skotarczak B. Adaptation Factors of Borrelia for host and vector. Ann Agric Environ Med. 2009, 16:1-8. 
58- Tsao Jl. Reviewing molecular adaptations of Lyme borreliosis spirochetes in the context of reproductive fitness in natural transmission cycles. Vet Res. 2009;40(2):36.

59- Sadziene A, Barbour AG, Rosa PA, Thomas DD. An OspB mutant of Borrelia burgdorferi has reduced invasiveness in vitro and reduced infectivity in vivo. Infect Immun. 1993;61(9):3590-6.

60- Fingerle V, Goettner G, Gern L, Wilske B, Schulte-Spechtel U. Complementation of a Borrelia afzelii OspC mutant highlights the crucial role of OspC for dissemination of Borrelia afzelii in Ixodes ricinus. Int J Med Microbiol.. 2007;297(2):97-107.

61- Sadziene A, Thomas DD, Barbour AG. Borrelia burgdorferi mutant lacking Osp: biological and immunological characterization. Infect Immun. 1995 ;63(4):1573-80.

62- Sadziene A, Thomas DD, Bundoc VG, Holt SC, Barbour AG. A flagella-less mutant of Borrelia burgdorferi. Structural, molecular, and in vitro functional characterization. J Clin Invest. 1991;88(1):82-92.

63- Motaleb MA, Sal MS, Charon NW. The decrease in FlaA observed in a flaB mutant of Borrelia burgdorferi occurs posttranscriptionally. J Bacteriol. 2004;186(12):3703-11.

64- Charon NW, Goldstein SF, Marko M, et al. The flat-ribbon configuration of the periplasmic flagella of Borrelia burgdorferi and its relationship to motility and morphology. J Bacteriol. 2009;191(2):600-7.

65- Margos G, Gatewood AG, Aanensen DM, et al. MLST of housekeeping genes captures geographic population structure and suggests a European origin of Borrelia burgdorferi. Proc Natl Acad Sci U S A. 2008;105(25):8730-5. 


\begin{tabular}{lcc}
\hline \multicolumn{1}{|c|}{$\begin{array}{l}\text { Table 1. Epidemiological, clinical and serological test in } \mathbf{8} \text { patients with } \\
\text { Date }\end{array}$} & $\begin{array}{c}\text { BYs } \\
\text { No } \\
\text { cases }\end{array}$ & $\begin{array}{c}\text { Frequency } \\
\text { (\%) }\end{array}$ \\
\hline Positive epidemiologic history & 8 & $100 \%$ \\
Bitten by tick & 4 & $50 \%$ \\
Flu-like symptoms (fever, headache, myalgia, arthralgia, chills, fatigue) & 7 & $87.5 \%$ \\
& & \\
Erythema migrans & 8 & $100 \%$ \\
Arthritis & 3 & $37.5 \%$ \\
Arthralgia & 6 & $75 \%$ \\
Positive serology for B. burgdorferi G39/40 & 3 & $37.5 \%$ \\
\hline
\end{tabular}

\begin{tabular}{|c|c|c|c|c|c|}
\hline Patient & Age & Onset of symptoms & Tratament & $\begin{array}{c}\text { Positive serology for } \\
\text { B burgdorfent }\end{array}$ & $\begin{array}{l}\text { PCR } \\
\text { flgE }\end{array}$ \\
\hline FM & 68 & 9 days & cephalexin for 4 days & - & - \\
\hline MAS & 51 & 30 days & none & - & - \\
\hline DFS & 31 & 60 days & cephalexin for 3 days & + & - \\
\hline JS & 67 & 11 days & none & + & + \\
\hline CCM & 30 & 105 days & none & - & - \\
\hline ORG & 60 & 270 days & none & + & + \\
\hline РMCP & 11 & 270 days & benzatine penicillin for 10 days & - & + \\
\hline ABPLS & 15 & 30 days & tetracycline for 7 days & - & + \\
\hline
\end{tabular}




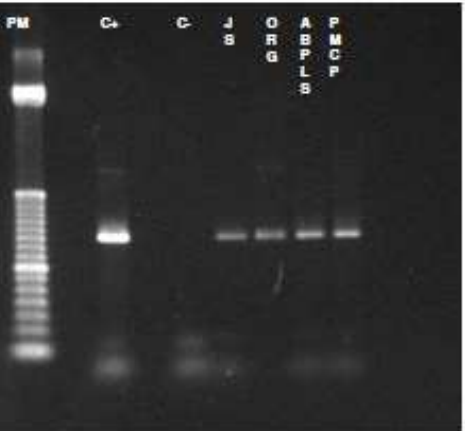


Figure 1: PCR flgE : $\mathrm{PM}=$ molecular weight $(50 \mathrm{bp}) ; \mathrm{C}_{+}=$B. garinï; $\mathrm{C}-=$ control group; JS, $O R G, A B P L S$ and $P M C P=B Y S$ patients.

Table 1. Epidemiological, clinical and serological test in 8 patients with BYS

Table 2. Patients follow-up, treatment with antibiotics, serology for Borrelia burgdorferi and PCR for flgE in 8 patients with BYS. 